\title{
PREPOZYTURA KIELECKA W XVI STULECIU. WIERNI I ICH DUSZPASTERZE
}

\section{Streszczenie}

W artykule przedstawiono duszpasterstwo parafialne w prepozyturze kieleckiej w XVI wieku. Podstawa źródłowa to przede wszystkim rejestr taksacyjny dochodów kleru diecezji krakowskiej z 1529 r., akta oficjała kieleckiego oraz księgi metrykalne kieleckiej kolegiaty zachowane od lat 60 . XVI wieku, a ponadto wizytacje z lat 90 . W XVI wieku prepozytura liczyła 29 parafii, w większości wiejskich. Nieliczne na tym obszarze małe miasta miały znaczenie gospodarcze i administracyjne wyłącznie jako centra okolicznych dóbr. Właściciele ziemscy w prepozyturze to z nielicznymi tylko wyjątkami instytucje kościelne, przede wszystkim biskupi krakowscy oraz klasztory: benedyktynów na Świętym Krzyżu i cystersów w Wąchocku. Stąd też, przeciwnie niż na terenach sąsiednich, patronat szlachecki odgrywał marginalną rolę, co skutecznie uniemożliwiało propagowanie idei reformacyjnych.

Beneficja parafialne prepozytury kieleckiej należały do najlepiej udotowanych w całej diecezji krakowskiej. Większość plebanów zatrudniała wikariuszy, na ogół jednego, sporadycznie dwu, odsetek zaś parafii z wikariuszami zmniejszył się z 79 do $62 \%$ w ciągu stulecia. O ile w 1529 r. wikariusze $44 \%$ parafii otrzymywali wynagrodzenie wyższe niż prepozyturalna średnia, to w 1597 r. takich parafii było już tylko 27\%. Podejmując decyzję o zatrudnieniu wikariusza, plebani nie kierowali się przede wszystkim wysokością beneficjalnych wpływów. Podobnie też często nie wiedzieli potrzeby zwiększania salariów swych podwładnych, choć stanowiły one tylko nikły procent dochodów. Istotną częścią dochodów wikariuszy były ofiary związane z szafowaniem sakramentów, o których wiadomo tylko tyle, że miały tendencję malejącą. W 1529 r. salaria wikariuszy kolegiaty kieleckiej to tylko 16\% szacunkowych dochodów kapituły. Analiza nielicznych zachowanych testamentów niższego

* Waldemar Kowalski - prof. dr hab. nauk humanistycznych, Instytut Historii, Uniwersytet Jana Kochanowskiego w Kielcach

e-mail:waldemar.kowalski@ujk.edu.pl

https://orcid.org/0000-0003-1692-338X 
kleru pokazuje, że ich autorzy wiedli życie dalekie od luksusu, ale też od permanentnej nędzy.

Proboszczowie i wikariusze pochodzili na ogół ze wsi i małych miast położonych w większości na terenie diecezji krakowskiej; duchowni pochodzenia szlacheckiego to, jak się zdaje, najwyżej $20 \%$ badanej populacji. W środowiskach tych edukację kończono w najlepszym razie w parafialnej szkole, czytelnictwo zaś było nieczęste. Najwyżej ok. 15\% badanej zbiorowości odebrała wykształcenie w krakowskiej akademii. Przygotowanie do posługi kończyło się więc zapewne na przyuczeniu przez własnego plebana. Do pracy duszpasterskiej w małomiasteczkowych i wiejskich parafiach, bardziej niż ponadprzeciętna erudycja książkowa, przydatna była znajomość środowiska, z którego księża pochodzili i w którym pracowali. Duchowni prepozytury kieleckiej świadomi byli wagi ksiąg dla duszpasterstwa, a pierwszorzędną pomocą był tu brewiarz, niekoniecznie rzymski. Jeszcze z końcem stulecia sięgano bowiem po dawne diecezjalne przewodniki liturgiczne. Stosunkowo rzadko wizytatorzy wzmiankują zbiory kazań, gdyż zapewne poprzestawano na wzorcowych kazaniach publikowanych w agendach diecezjalnych. Księgozbiory parafialne, a także nieliczne prywatne wikariuszy i plebanów, rzadko liczyły więcej niż kilka tomów. Były to na ogół dzieła przydatne w liturgii i duszpasterstwie, choć katechizmy pojawiają się rzadko.

O tym, że brak jest prostej zależności między liczbą tomów parafialnej biblioteki, tj. możliwością samokształcenia i podnoszenia kwalifikacji, a zaangażowaniem w pracę duszpasterską, informuje przykład kieleckiej parafii. Od lat 60. do schyłku stulecia, 8 wikariuszy tamtejszej kolegiaty obejmowało swą opieką tylko niewielką część z ok. 5500 parafian. W latach 1597-1598 bractwa religijne odnotowano tylko w ok. 20\% parafii, ich aktywizacja zaś w kolejnych latach postępowała opornie.

Dostępne źródła sugerują, że nie było łatwo zaangażować świeckich w życie religijne parafii ponad niedzielną naukę podstawowych modlitw i ofertoria. Życie religijne, relacje duchownych i świeckich w prepozyturze kieleckiej drugiej połowy XVI wieku to nadal świat prowincji późnego średniowiecza. Tak bowiem jak na przełomie XIV/XV wieku, tak również dwa stulecia później program reformy życia religijnego sprowadzał się do umocnienia dyscypliny świeckich i duchownych.

Słowa kluczowe: diecezja krakowska; reforma Kościoła; duszpasterstwo; biblioteki; testamenty; dyscyplina kościelna

$* * * * *$

XVI wiek był tym stuleciem, w którym zapadły decyzje o kluczowym znaczeniu dla dalszych dziejów polskiego Kościoła i religijności Polaków - aż do czasów nam współczesnych. Doniosłość rozpoczętej po 1517 r. reformacji protestanckiej oraz kontynuowanej, po części w odpowiedzi nań, reformy katolickiej nie może zostać właściwie oceniona bez wnikliwej rekonstrukcji świadomości religijnej wiernych i ich duszpasterzy. Drogą do tego są studia nad formami i skutecznością parafialnej cura animarum. Niestety, systematyczne badania w tym względzie prowadzone są od niedawna, co więcej, mają charakter przypadkowy i wycinkowy, a ponadto prowadzone są głównie dla schyłku stulecia. Z tych względów wiek przełomu, w którym średniowieczne praktyki adaptowano do no- 
wych potrzeb, rzadziej zaś zdecydowanie odrzucano, często równany bywa z czasami baroku. Taka perspektywa patrzenia na religijność XVI wieku daje uproszczony i zafałszowany obraz. Niniejszy tekst przynosi wyniki analizy relacji między świeckimi a klerem parafialnym prepozytury jako istotnych uwarunkowań jakości opieki duszpasterskiej. Analiza ta uwzględnia szersze uwarunkowania społeczne, ale i regionalną specyfikę, którą określają stosunki własnościowe oraz zakres urbanizacji. Piszący te słowa jest bowiem przekonany, że tylko takie postępowanie badawcze ustrzec może od zbyt pochopnych i nieusprawiedliwionych uogólnień ${ }^{1}$.

Dostępne źródła poniekąd zmuszają, aby na opiekę duszpasterską patrzeć z perspektywy okoliczności, które w opinii współczesnych warunkowały jej skuteczność. Uwarunkowania te można poznać głównie z akt synodalnych oraz z protokołów pierwszych wizytacji². Wysłannicy biskupi rozwijali o lokalnie zanotowane szczegóły tzw. articuli ad visitationem, to jest zagadnienia sformułowane podczas synodów czy w listach pasterskich. Dla prepozytury kieleckiej w omawianym okresie zachowała się jedynie wizytacja zewnętrzna przeprowadzona za pasterzowania kardynała Jerzego Radziwiłła, rozpoczęta 4 września i zakończona najpewniej $\mathrm{w}$ drugiej połowie listopada $1597 \mathrm{r}^{3} \mathrm{~W}$ roku następnym kardynał odwiedził niektóre miasta diecezji, m.in. Kielce, Iłżę i Bodzentyn, poczynione zaś przy tej okazji pouczenia odnoszą się także do zagadnień obyczajowych i moralnych ${ }^{4}$. Obraz, jaki przedstawiają te protokoły, uzupełnia nieco kolejna lustracja parafii prepozytury kieleckiej, odbyta w $1610 \mathrm{r}^{5}$; pomocne są też diecezjalne spisy kontrybucji (tzw. subsidium charitativum) ${ }^{6}$ oraz zachowane częściowo akta oficjała kieleckiego ${ }^{7}$. Wszystkie te źródła, a ponadto wyjątkowo wczesne księgi metrykalne kieleckiej kolegiaty, z wpisami zaczynającymi się w $1565 \mathrm{r}^{8}$, pozwa-

${ }^{1}$ Konieczności odwołania się do takich metod badawczych szeroko dowiódł J. Chachaj, Bliżej schizmatyków niż Krakowa... Archidiakonat lubelski w XV i XVI wieku, Lublin 2012.

${ }^{2}$ Znaczna liczba publikacji szczegółowych zmusza do wyboru istotniejszej tu literatury. Przywoływane dalej opracowania dotyczą więc przede wszystkim prowincji gnieźnieńskiej, a w niej diecezji krakowskiej. Zob. m.in. L. Zygner, Późnośredniowieczne synody narzędziem reformy Kościoła, w: Ecclesia semper reformanda. Kryzysy i reformy średniowiecznego Kościoła, red. T. Gałuszka, T. Graff, G. Ryś, Kraków 2013, s. 423-441; B. Kumor, Dzieje diecezji krakowskiej do roku 1795, t. 2., red. J. Urban, Kraków 1999, s. 138-148; R. Kuśmierczyk, Problematyka „Listu pasterskiego” kard. Jerzego Radziwiłła z roku 1593, „Nasza Przeszłość”, 100 (2003) s. 223-256; T. Glemma, Wizytacje diecezji krakowskiej z lat 1510-1570, „Nasza Przeszłość”, 1 (1946) s. 43-96.

${ }^{3}$ Archiwum Kurii Metropolitalnej w Krakowie, Acta visitationis capitularis (dalej: AKMKr, AV Cap), sygn. 8. Przeredagowana kopia tych zapisów włączona została do AKMKr, AV Cap 65. Okoliczności przeprowadzania wizytacji oraz ich wartość poznawczą przybliżył J. Kracik, Zasoby Archiwum Kurii Metropolitalnej w Krakowie, „Analecta Cracoviensia”, 9 (1977) s. 476-477.

${ }^{4}$ AKMKr, AV Cap 9.

${ }^{5}$ AKMKr, AV Cap 30.

${ }^{6} \mathrm{O}$ źródłach tych szerzej zob. H. Karbownik, Ciężary stanu duchownego w Polsce na rzecz państwa od r. 1381 do połowy XVII wieku, Lublin 1980, s. 128-160.

${ }^{7}$ AKMKr, Acta officialatus Kielcensis, sygn. A. Off. 1 (dalej: AKMKr, A. Off. 1).

${ }^{8}$ Analizuję je w kontekście duszpasterstwa w kieleckiej kolegiacie pw. NMP w artykule Trydenckie wyzwania a duszpasterstwo w kieleckiej parafii kolegiackiej drugiej połowy XVI wieku, 
lają przybliżyć badane zagadnienia9 ${ }^{9}$ Ogląd problemu ograniczony jest urzędowym, formalnym charakterem dostępnych źródeł oraz ich szczupłością ${ }^{10}$. Możliwe jest więc jedynie przybliżenie postaw moralnych i horyzontów umysłowych księży oraz, w niewielkim stopniu, ich relacji ze świeckimi. Istotne poznawczo wydaje się tu prześledzenie roli książki w życiu duchownego. Służyć temu ma nie tylko analiza liczby posiadanych druków i ich tytułów, lecz także obserwacja więzi emocjonalnych, czytelnych niekiedy w relacjach o takich zbiorach ${ }^{11}$. Niniejsze opracowanie pomija natomiast szpitale i szkoły. Nie negując ich znaczenia dla parafialnego duszpasterstwa, należy jednak mieć świadomość, że stosowne informacje służyć mogą prawie wyłącznie ujęciu statystycznemu. Dla pogłębienia wiedzy o cura animarum taka perspektywa ma więc znikomy pożytek.

Przypomnieć wypada, że skuteczność duszpasterstwa oceniano wówczas przede wszystkim przez pryzmat wypełniania formalno-prawnych rygorów. Choć dziś nie sposób zaprzeczyć słuszności egzekwowania norm wynikających z prawa Bożego i stanowionego, nie można też nie zauważyć, że spojrzenie to bynajmniej nie wyczerpuje wszechstronnej oceny skuteczności działań ówczesnego Kościoła oraz relacji między człowiekiem a Bogiem. Stan zachowania źródeł nie zwalnia jednak od badań, z których praktyczne korzyści płynąć mogą także dla refleksji o czasach nam współczesnych.

W XVI-XVII stuleciu zakres obowiązków pastoralnych formułowany był tak, jak w wiekach średnich ${ }^{12}$. Sobór Trydencki utrzymał bowiem wzorzec kapłana, którego służba podporządkowana była składaniu ofiary mszy świętej i odpuszczaniu grzechów. Głoszenie Słowa Bożego pozostawało w cieniu tej sakramentalnej władzy. Instrukcje pastoralne podkreślały godność i prawość duszpasterza, który potrafi dotrzeć do swych owieczek z Dobrą Nowiną i jest dla nich wzorem na co

w: Jednostka, rodzina i struktury społeczne w perspektywie historycznej. Ksiegga jubileuszowa dedykowana Profesorowi Cezaremu Kuklo, red. P. Łozowski, R. Poniat, Warszawa 2021 (w druku).

${ }^{9}$ Nie zachowały się niestety XVI-wieczne akta kieleckiej kapituły większej i mniejszej oraz księgi wspomnianych miast.

${ }^{10}$ Nie ulega wątpliwości, że pominięte w tym opracowaniu akta ordynariusza i jego oficjała generalnego posłużyłyby co najwyżej do wzbogacenia kreślonego tu obrazu o dość typowe informacje szczegółowe, jak m.in. instalacje na beneficja, fundacje czy konflikty dziesięcinne. Nie negując wartości poznawczych tej dokumentacji, podkreślić trzeba jej znikomą przydatność dla studiów nad praktycznymi aspektami duszpasterstwa. Por. K. Górski, Zarys dziejów duchowości w Polsce, Kraków 1986, s. 8, 14.

${ }^{11}$ Podobną opinię wyraził A. Ottone, Pastoral Care and Cultural Accuracy: Book Collections of Secular Clergy in Three Southern Italian Dioceses, w: Documenting the Early Modern Book World: Inventories and Catalogues in Manuscript and Print, red. M. Walsby, N. Constantinidou, Leiden-Boston 2013, s. 232. Nadto zob. R. A. Wood, The Ownership of Books amongst the London Rectors in the Late Fourteenth and Fifteenth Centuries, „Medieval Prosopography”, 33 (2018) s. 197.

${ }^{12}$ Zmiany przyniosły tu dopiero czasy stanisławowskie, o czym M. Ślusarska, Odnowa życia kościelnego i pogłębienie świadomości religijnej wiernych w świetle zaleceń przedstawicieli episkopatu Rzeczypospolitej Obojga Narodów w XVIII wieku - rekonesans, w: Wiek XVIII - między tradycją a oświeceniowa wspótczesnością. Hermeneutyka wartości religijnych, red. B. Kuczera-Chachulska, T. Chachulski, współpraca J. Snopek, Warszawa 2017, s. 105-155. 
dzień ${ }^{13}$. Takie oczekiwania teologów i władz diecezjalnych słabo jednak przystawały do realiów epoki. O nich zaś stanowiły: beneficjalny system dochodzenia do kapłaństwa, utrzymanie po Trydencie w mocy kumulacji beneficjów oraz powszechnie słaba kondycja moralna i intelektualna parafialnego kleru ${ }^{14}$. Światli biskupi-reformatorzy, jak choćby stojący na czele krakowskiego Kościoła: Jan Konarski (1503-1524), Franciszek Krasiński (1572-1577) czy Jerzy Radziwiłł (1591-1600), wolno sądzić, świadomi byli wspomnianych ograniczeń. Podejmowali więc działania, których celem była poprawa jakości cura animarum w otaczającym ich świecie; nie byli jednak w stanie zreformować go w stopniu, w którym niezbędne zmiany korzystnie i trwale wpłynęłyby na jakość duszpasterstwa ${ }^{15}$.

Eksponowanie w protokołach wizytacji źródeł dochodu beneficjum i ich integralności jednoznacznie wskazuje na pierwszoplanową - w opinii współczesnych - wagę materialnego zaplecza dla należytego wypełniania obowiązków duszpasterskich. Wskazać należy dwa aspekty tego zagadnienia: materialny, związany z potrzebą zapewnienia odpowiednich warunków do godnego życia, oraz społeczny - w hierarchicznym świecie ubogi duchowny nie mógł liczyć na szacunek majętniejszych chłopskich czy szlacheckich parafian ${ }^{16}$. Porównywanie długich wykazów pól, dziesięcin oraz czynszów niekoniecznie doprowadzić musi do poprawnej oceny wielkości beneficjalnego dochodu. Wiarygodnym wskaźnikiem jest tu natomiast oszacowana dla celów podatkowych wartość beneficjum. Orientuje ona w hierarchii dochodów parafii prepozytury oraz pozwala ocenić jej miejsce w tym względzie w skali całej diecezji. Sporządzona w 1529 r. księga retaksacji ${ }^{17}$ jest jedyną podstawą do takich wniosków. Valor beneficii, o którym informuje, to wszelkie dochody oprócz tych, których dostarczało własne gospodarstwo. Wzorem poboru łanowego retaksacja nie objęła bowiem dochodów z folwarku plebańskiego. Pominięto także ofiary przysługujące prawem stuły ${ }^{18}$. Oszacowanie ich wielkości byłoby możliwe pod warunkiem znajomości liczby ludności w parafiach. Takich danych jednak brak. W bardzo niedoskonałym stopniu zastę-

${ }^{13}$ Zob. I. Skierska, Pleban w późnośredniowiecznej Polsce, w: Kolory i struktury średniowie$c z a$, red. W. Fałkowski, Warszawa 2004, s. 155-182; K. Dola, Duchowieństwo w społeczeństwie polskim w przededniu reformacji (1450-1520), w: Studia nad poczatkami reformacji protestanckiej na Ślasku, Opole 2009, s. 23-49.

${ }^{14} \mathrm{O}$ tym przede wszystkim J. Kracik, Potrydencki system rekrutacji duchowieństwa $w$ diecezji krakowskiej XVI-XVIII wieku, „Analecta Cracoviensia”, 10 (1978) s. 471-493; tenże, Prawie wielebni, Kraków 2011.

${ }^{15}$ Zob. przede wszystkim S. Litak, Od reformacji do oświecenia. Kościół katolicki w Polsce nowożytnej, Lublin 1994, s. 58-61; J. Kracik, Przeciw reformacji, w: Kościót krakowski w tysiacleciu, Kraków 2000, s. 172-248.

${ }^{16}$ Por. Kracik, Prawie wielebni, s. 108.

${ }^{17}$ Księga dochodów beneficjów diecezji krakowskiej z roku 1529 (tzw. Liber retaxationum), wyd. Z. Leszczyńska-Skrętowa, Wrocław 1968 (dalej: LR); zob. też W. Kowalski, Uposażenie parafii archidiakonatu sandomierskiego $w$ XV-XVIII wieku, Kielce 1998, s. 88-89, gdzie starsza literatura. Ponadto M.D. Kowalski, Dzieje autografu katedralno-kolegiackiej części Liber beneficiorum dioecesis Cracoviensis Jana Dlugosza, „Studia Źródłoznawcze”, 46 (2009) s. 87.

${ }^{18}$ Por. Karbownik, Ciężary stanu duchownego, s. 155-156. 
pują je liczby osad, które w tabeli 1 zestawiono z ogólnymi dochodami poszczególnych beneficjów plebańskich prepozytury kieleckiej ${ }^{19}$.

Analiza danych zawartych w tabeli 1 pokazuje znaczne dysproporcje w dochodach poszczególnych parafii, co nie jest zaskoczeniem. 63\% beneficjów przynosiło ich dzierżawcom wpływy niższe niż średni na badanym obszarze (21 grzywien i 7 gr.). W tym samym czasie na terenie sąsiedniego archidiakonatu sandomierskiego 53\% parafii miało dochody oszacowane niżej niż tamtejsza średnia wynosząca 28 grzywien i 3 gr. Suma dochodów najmniej intratnego beneficjum w prepozyturze, parafii Zbelutka, to tylko 5\% tego, czego oczekiwać mógł dzierżawca najbogatszego beneficjum plebańskiego w Iłży. Na podstawie danych zawartych tabeli 1 można dowieść też, że lepiej uposażone były beneficja plebańskie tych parafii, których okręgi liczyły więcej osad. Są to również najstarsze parafie o wczesnośredniowiecznej metryce ${ }^{20}$. Wzmiankowane skrajności w wysokości dochodów nie były niczym wyjątkowym. Motywacja do dochodzenia do lepiej uposażonego beneficjum jest więc oczywista.

Błędne byłoby jednak mniemanie, że rządca nawet słabo udotowanego beneficjum chronicznie cierpiał biedę. Na wsparcie, o zapewne zmiennej wysokości, o którym wiadomo niewiele więcej niż to, że było udziałem zdecydowanej większości beneficjantów, składały się tzw. akcydensy, czyli ofiary dawane prawem stuły oraz podczas mszy, dochody z gospodarstwa plebańskiego, a ponadto dziedziczny majątek księdza. Pamiętać też trzeba, że - tak jak w innych epokach podstawę opodatkowania szacowano poniżej realnego valoris beneficii. Zarówno prepozytura kielecka, jak i archidiakonat sandomierski należały do tych okręgów administracyjnych rozległej diecezji krakowskiej, w których znajdowało się najwięcej zasobnych parafii ${ }^{21}$.

W tabeli 2 pokazano, że w ciągu stulecia liczba parafii, których rządcy zatrudniali wikariuszy, spadła z 79 do $62 \%$. W 1577 r. z 23 czynnych parafii, nie licząc kolegiackiej, wikariuszy zatrudniano w $13(57 \%)^{22}$. Średnia wikariuszy na parafię prepozytury kieleckiej w 1529 r. $(0,58)$ zbliżona jest do wielkości obliczonej dla innych terenów diecezji krakowskiej - 0,48-0,64 w latach 1513-1539²3. O ile

${ }^{19}$ Według B.S. Kumora (Dzieje diecezji krakowskiej do roku 1795, red. J. Urban, t. 4, Kraków 2002, s. 362) u schyłku XVI wieku tylko 43 parafie w całej diecezji liczyły więcej niż 15 wsi. Na terenie prepozytury kieleckiej takimi okręgami były: Iłża, Łagów, Świętomarz, Waśniów i Wąchock. Dodać tu trzeba też parafię kieleckiej kolegiaty, o czym dalej.

${ }^{20}$ Zob. M. Grabkowski, Ksztaltowanie się sieci parafialnej w prepozyturze kieleckiej w czasach średniowiecza, „Res Gestae”, 12 (2012) s. 77-109; P. Kardyś, Parafie w średniowieczu na obszarze obecnej diecezji kieleckiej: stan i perspektywy badań, „Kieleckie Studia Teologiczne”, 13 (2014) s. 49-68.

${ }^{21}$ Szerzej zob. E. Wiśniowski, Wartość beneficjów plebańskich $w$ diecezji krakowskiej w świetle księgi dochodów beneficjów z roku 1529, „Roczniki Humanistyczne”, 35 (1987) s. 71-81; ponadto Kowalski, Uposażenie parafii, s. 88-92, 237-239. Na znaczną rozpiętość wartości beneficjów parafialnych, ale też na relatywnie niezłe dochody większości z nich wskazał Chachaj, Bliżej schizmatyków, s. 108-111.

${ }^{22}$ AKKKr, Akp, sygn. Reg. C7, k. 126r.-129v.

${ }^{23}$ E. Wiśniowski, Materiały do stanu liczebnego duchowieństwa i stużby kościelnej $w$ diecezji krakowskiej w pierwszej połowie XVI w., „Archiwa, Biblioteki i Muzea Kościelne”, 18 (1969) s. 191. 
w 1529 r. wikariusze 44\% parafii otrzymywali wynagrodzenie wyższe niż prepozyturalna średnia, to w 1597 r. takich parafii było już tylko $27 \%{ }^{24}$. Choć zestawione w tabeli sumy są w poszczególnych parafiach nominalnie większe u schyłku stulecia niż u jego początków, fałszywy byłyby wysunięty stąd wniosek o znaczącym wzroście dochodów tych księży. Nominalny wzrost wynikał bowiem zapewne głównie z inflacji. Jeśli podjąć się na tej podstawie oceny zmiany materialnego położenia niższego kleru parafialnego, to zapewne było ono nieco gorsze; być może wprost proporcjonalnie do wzrostu liczby parafii, w których nie osiągano przeciętnego wynagrodzenia. Dodatkowo wzrost obciążeń pańszczyźnianych oraz spadek dochodów chłopskich odbijał się bez wątpienia na tej części dochodów wikarych, którą stanowiły ofiary wiernych ${ }^{25}$.

Zatrudnianie więcej niż jednego wikariusza było rzadkością. W 1529 r. dwóch takich księży można spotkać tylko w $22 \%$ spośród wszystkich parafii prepozytury kieleckiej, w których wikariuszy odnotowano. W 1577 r. było tylko 5 takich parafii (38\%), na ogólną liczbę 13, w których odnotowano kler pomocniczy. W $1597 \mathrm{r}$. odsetek kościołów, przy których zastano dwu lub więcej wikarych to 25, jednak przy wzroście liczby parafii, w których w ogóle nie zatrudniano niższego kleru. Analiza związku między wielkością dochodów beneficjum plebańskiego a wysokością lokalnie wypłacanych salariów potwierdza wcześniejsze obserwacje, że o możliwości i potrzebie zatrudnienia duchownego prowiza niekoniecznie decydowała sytuacja materialna plebana, a tym bardziej rozległość parafii ${ }^{26}$. Trzeci istotny tu czynnik, z trudem poddający się ocenie, to kumulacja beneficjów, która prawnie obligowała do znalezienia następcy ${ }^{27}$.

${ }^{24}$ Średnia dla archidiakonatu sandomierskiego w 1529 r. to także 144 gr, lecz ponadprzeciętne salaria płacono tam w 70\% parafii; Kowalski, Uposażenie parafii, s. 195-197.

${ }^{25}$ Por. J. Topolski, Przełom gospodarczy w Polsce XVI wieku i jego nastęstwa, Poznań 2000, s. 68-78; P. Guzowski, Chłopi i pieniądze na przełomie średniowiecza i czasów nowożytnych, Kraków 2008, s. 48. Na wielość źródeł dochodów niższego kleru, różnice między oczekiwanymi a realnymi wpływami oraz wynikające stąd trudności wiarygodnej oceny poziomu życia tych księży zwróciła uwagę E. Wółkiewicz, The Ecclesiastical Proletariat? The Income of the Lesser Clergy in the late Middle Ages Exemplified with the Accounting Book of St. Martin's Altar in Nysa, „Kwartalnik Historii Kultury Materialnej”, 67 (2019) s. 3-16.

${ }^{26}$ Lepsza sytuacja istniała w tym względzie np. w archidiakonacie włocławskim; zob. R. Kuśmierczyk, Problem braku duchowieństwa parafialnego $w$ archidiakonacie włocławskim $w$ końcu XVI w., w: Nad spoleczeństwem staropolskim, t. 1: Kultura, instytucje, gospodarka w XVI-XVIII stuleciu, red. K. Łopatecki, W. Walczak, Białystok 2007, s. 363-365; O provisio obligatoria; zob. szerzej Kracik, Prawie wielebni, s. 66-86; tenże, Potrydencki system, s. 477-480.

${ }^{27}$ Kardynał Jerzy Radziwiłł w liście do rządców diecezji krakowskiej nierezydencję dopuszczał jako sytuację wyjątkową i tylko pod ścisłe określonymi warunkami; Kuśmierczyk, Problematyka, s. 233. Z ustaleń E. Wiśniowskiego (Liczebność duchowieństwa diecezjalnego na ziemiach polskich w pierwszej połowie XVI w., „Roczniki Humanistyczne”, 16, 2 (1968) s. 48-51) wynika, że odsetek duchownych kumulujący beneficja w diecezji krakowskiej w 1529 r. to między ok. 23 a 26\%, przy czym odsetek kumulujących plebanów to $28 \%$. Brak powodów, dla których można by zakładać radykalne zmiany w tym względzie w kolejnych dekadach, ale trudno tu o pewność. W 1577 r. beneficja kumulowało dowodnie i/lub nie rezydowało tylko trzech rządców parafii (26\%); AKKKr, Akp, sygn. Reg. C7, k. 126r.-129v. Nie sposób jednak wykluczyć obejmowania beneficjów poza diecezją 
Nawet przy założeniu, że część dochodów plebańskich przeznaczana była pro fabrica ecclesice ${ }^{28}$, do wikariuszy zaś trafiały ofiary wiernych, to i tak dysproporcje wysokości uposażenia obu kategorii duchowieństwa są ogromne. Źródła, które są do dyspozycji, nie pozwalają przybliżyć dochodów i rozchodów gospodarstw plebańskich na badanym terenie. Można jednak przyjąć, że nie różniły się one znacząco od tego, co wiadomo na ten temat dla sąsiedniego archidiakonatu sandomierskiego. Czysta intrata stanowiła tam przeciętnie ok. $40 \%$ przychodu, czyli dochodu brutto. Rozchody to więc ok. $60 \%$ przychodów; z tego ok. $25 \%$ przeznaczano na wydatki związane $\mathrm{z}$ utrzymaniem personelu duchownego i świeckiego (nauczyciela, kantora, dzwonnika), a 75\% - na utrzymanie gospodarstwa i kościo$\mathfrak{ł a}^{29}$. Proporcje te pokazują, że na ogół istniały rezerwy pozwalające zwiększyć salaria wikariuszy. Największe w prepozyturze kieleckiej sumy przekazywano na ten cel w Świętomarzy i stanowiły one $17 \%$ valoris beneficii według taksacji 1529 r. ${ }^{30}$ Jednak w Tarczku, gdzie salaria były najniższe, odnotowuje się podobne, gdyż $14 \%$ takie obciążenie dochodów plebańskich. Sytuacje skrajne były z początkiem XVI stulecia na badanym terenie wyjątkowe; w Mychowie salarium to aż 30\% valoris beneficii. W miejskich, relatywnie bardzo dobrze uposażonych farach w Lagowie i Waśniowie (zob. tabele 1 i 2) w ogóle nie zatrudniano wikariuszy, co nie znaczy, że nie było takiej potrzeby. Dostrzegali to wizytujący parafie, czego świadectwem jest np. uwaga poczyniona w Zbylutce w 1597 r. Pleban Łagowa, któremu świątynia ta podlegała jako filia, nie trzymał tam wikarego, choć - jak podkreślono - pozwalało na to uposażenie kościoła, nieuszczuplone w porównaniu z zapisami w Liber beneficiorum ${ }^{31}$.

Solidność wniosków płynących z danych zestawionych w tabelach 1 i 2 musi pozostać dyskusyjna. Czerpane z różnych, raczej nieobfitych źródeł dodatkowe dochody nieprzeliczone na grosze i grzywny z pewnością wahały się w poszczególnych latach, a zapewne też w różnych porach roku. Jak zaświadcza wizytacja 1597 r., wspólny stół dzielony z plebanem był już wtedy rzadkością. Wyjątkowo dobre zaopatrzenie mansjonarzy iłżeckich wynikało $\mathrm{z}$ ich statusu beneficjatów ${ }^{32}$. Pobliskie beneficjum plebańskie w Wąchocku zajmowało, co prawda, dopiero

krakowską, choć nie było to z pewnością zjawisko masowe. J. Kracik (Potrydencki system, s. 477) zauważył, że beneficja kumulowała prawie bez wyjątku szlachta, a tej wśród duchowieństwa parafialnego prepozytury było niewiele.

${ }^{28}$ Wysokość takich nakładów względem całkowitych dochodów beneficjum parafialnego albo nie była przedmiotem debat synodalnych, albo nie została udokumentowana w protokołach; K.R. Prokop, Fabrica ecclesice. Budowa i utrzymanie katolickich miejsc kultu w diecezji krakowskiej w czasach nowożytnych, Warszawa-Kraków 2011, s. 63-68.

${ }^{29}$ Zob. Kowalski, Uposażenie parafii, s. 96-99, 247-248. O braku konsekwentnej polityki władz diecezjalnych w tym względzie wspomina Kracik, Potrydencki system, s. 488-489.

${ }^{30}$ Taksacja ta obowiązywała także w kolejnych dekadach.

${ }^{31}$ AKMKr, AV Cap 8, s. 50.

${ }^{32}$ Mansjonarię erygowano tam w 1483 r.; zob. Wiśniewski, Dekanat ilżecki, Radom 1911, s. 83; F. Kiryk, Urbanizacja rejonu między Itżanka, Kamienną i Wisłą do końca XVI stulecia, w: „Annales Universitatis Pedagogicae Cracoviensis, Studia Logopaedica IV: Język - kultura - edukacja" 96 (2011), s. 248; por. B. Szady, Prawo patronatu w Rzeczypospolitej w czasach nowożytnych, Lublin 2003, s. $140-141$. 
środkowe miejsce w hierarchii dochodów parafii prepozytury kieleckiej. Jednak tamtejsi wikariusze liczyć mogli nie tylko na stosunkowo wysokie roczne pensje, ale $\mathrm{i}$ wyjątkowo niemałe wspomożenie $\mathrm{w}$ naturaliach od cystersów, właścicieli osady, oraz od mieszczan ${ }^{33}$. Błędem byłoby jednak rozciąganie tej opinii na całe stulecie. Oto bowiem w 1577 r. jedyny iłżecki mansjonarz Jan Modrenius, pełniący funkcję wiceprepozyta, skarżył się, iż nie dostaje należnych dziesięcin i czynszów. Beneficjum to kumulował ze szpitalnym i zapewne ono właśnie było podstawą jego utrzymania. Nie odnotowano w tym roku, ilu księży posługiwało w wąchockiej parafii, ale kontrybucja została opłacona ${ }^{34}$.

W tabeli 3 zaprezentowano nie tylko znaczące różnice w dochodach poszczególnych członków kapituły kieleckiej i ich zastępców, lecz także istotne dysproporcje między salariami wikariuszy a dochodami prałatów i kanoników, których zastępowali. O ile wiceprepozyt, wicedziekan i wicekustosz cieszyli się honorariami znacznie przewyższającymi nawet najlepiej uposażonych wikariuszy wiejskich i małomiasteczkowych far, to nie można powiedzieć tego o wikariatach kanonii. Jednak nawet najuboższy wikariat kanonii fundi Żydów istotnie przewyższał atrakcyjnością dochodów propozycje składane kandydatom na wikariuszy innych parafii prepozytury kieleckiej. Za tym, że posada zastępcy prałata i kanonika kolegiackiego warta była zachodu, przemawia ponadto liczba ludności. Kielce bowiem, podobnie jak trzy inne miasta prepozytury (Bodzentyn, Iłża i Daleszyce), liczyły ponad 1000 mieszkańców ${ }^{35}$.

Częściową weryfikację zagadnienia materialnego bytowania kolegiackich wikariuszy umożliwiają znane testamenty. Księga, do której zostały skopiowane, rozpoczyna się jednak dopiero w 1551 r. ${ }^{36}$ Ponadto, z bliżej nieznanych powodów, przekazuje treść tylko pięciu takich dyspozycji, kilka zaś innych jedynie odnotowano bez przytaczania ich treści. Nie jest to liczba reprezentatywna ani dla kieleckiej kapituły mniejszej, a tym bardziej dla ogółu duchowieństwa prepozytury. Stan ten może wydawać się zaskakujący, zasadność bowiem spisywania ostatniej woli duchownych oraz inwentarzy ich mienia rekomendowano statutami synodalnymi ${ }^{37}$. Niewykluczone, że zalecenia te były ignorowane lub nie uważano za celowe, aby testament w każdym przypadku przedstawiać oficjałowi; bardziej pole-

${ }^{33}$ Prawa parafialne należały tam do konwentu. O mieście tym zob. P. Kardyś, Z dziejów miasta klasztornego Wąchocka w średniowieczu i okresie wczesnonowożytnym: warstwa źródlowa i interpretacje historyczne, „Nasza Przeszłość”, 123 (2015) s. 247-263.

${ }^{34}$ Archiwum Kapituły Katedralnej w Krakowie, Akta kontrybucji parafialnych (dalej: AKKKr, Akp) sygn. Reg. C7, k. 126v., 129r.

${ }_{35}$ Iłża mogła ewentualnie zbliżać się do tej wielkości; A. Dunin-Wąsowiczowa, Charakter $i$ wielkość osiedli, w: Województwo sandomierskie w drugiej połowie XVI wieku, red. W. Pałucki, cz. 2: Komentarz, indeksy, red. S. Trawkowski, oprac. K. Chłapowski i in., Warszawa 1993, s. 81-83.

${ }^{36}$ Zob. W. Wójcik, Organizacja i działalność oficjalatu okręgowego w Kielcach w latach 15511635, „Roczniki Teologiczno-Kanoniczne”, 10 (1963) z. 3, s. 29-37.

${ }^{37}$ Najstarsze statuty synodalne krakowskie biskupa Nankera z 2 października 1320 r., wyd. J. Fijałek, Kraków 1915, s. 52-53; Statuty synodalne wieluńsko-kaliskie Mikołaja Trąby z r. 1420 z materiałów przysposobionych przez B. Ulanowskiego, wyd. J. Fijałek, A. Vetulani, Kraków 19151920-1951, s. 54-57. 
gano na środowiskowej pamięci. Paweł Bratek, pleban w Potoku, zapisał swemu kościołowi dwa woły, a legat udokumentował w starym mszale złożonym w zakrystii świątyni ${ }^{38}$. Nakaz spisywania testamentów rzadko powraca w późnośredniowiecznych i XVI-wiecznych synodaliach; odnotowano w nich natomiast zgony księży bez oświadczenia ostatniej woli ${ }^{39}$.

Kielczanin Maciej Gil dyktował swój testament w 1538 r., w swym domu w Bodzentynie, jako że był tam wikarym. O jego nienajgorszym statusie materialnym świadczy przede wszystkim folwark z ogrodem przy szpitalu Św. Ducha extra muros, którego pół legował prepozytowi, pół zaś ubogim. Bractwu ubogich zapisał łąkę w okolicznym lesie ${ }^{40}$. Kolejny znany in extenso taki dokument, testament Stanisława Dźwiga z Bodzentyna, podyktowany został w 1574 r. w domu jego patrona, dziekana kapituły Wawrzyńca Gozdzkiego. Spośród bliskich najlepiej uposażył służącą Annę, której legował m.in. 11 krów. Swej siostrzenicy, która również służyła w jego domu, dał krowę i cielaka, świnię zaś ubogim. Srebrnymi łyżkami rekompensował trudy związane ze spisaniem i egzekucją jego testamentu ${ }^{41}$.

Wikary kolegiacki Piotr z Brzezin w diecezji gnieźnieńskiej zatroszczył się przede wszystkim o swój pogrzeb, czego świadectwem jest testament spisany w 1580 r. Miała to być wystawna uroczystość, z udziałem m.in. bractw oraz miejscowej szkoły. 50 fl. legował wspólnocie kolegiackich wikariuszy, 20 - „in patriam, ubi parentes sepulti sunt", 10 fl. na msze czytane o Pięciu ranach Zbawiciela ${ }^{42}$ do klasztoru na Łyścu, a ponadto $5 \mathrm{fl}$. do pobliskiego bernardyńskiego eremu św. Katarzyny ${ }^{43}$, aby jego bracia celebrowali msze czytane w kościele świętokrzyskich benedyktynów. Zdaje się, że pewne widoki na realizację miała egzekucja 100 grzywien długu od szlacheckich właścicieli Gumienic, skoro połowę tej sumy

${ }^{38}$ Pozwalało to ufać w modlitewną pamięć przyszłych pokoleń; zob. P. Sczaniecki, Stużba Boża w dawnej Polsce. Studia o Mszy świętej, Kraków 2020, s. 449. W 1599 r. woły zagarnął starosta szydłowski i stąd informacja o takim wpisie; AKMKr, AV Cap 30, k. 45r.

${ }^{39}$ I. Subera, Synody prowincjonalne arcybiskupów gnieźnieńskich. Wybór tekstów ze zbioru Jana Wężyka z r. 1761, Warszawa 1981, s. 100 i passim.

${ }^{40}$ AKMKr, A. Off. 1, k. 12-12v. Zob. też L. Poniewozik, Średniowieczny kościót i parafia w Bodzentynie, w: Bodzentyn. Studia z dziejów miasta, red. K. Bracha, B. Wojciechowska, Kielce 2005, s. $101,107$.

${ }^{41}$ AKMKr, A. Off. 1, k. 132v.-135v. Na marginesie zauważyć warto popularność srebrnych łyżek wśród księży diecezji krakowskiej (jako lokaty kapitału?). Część z nich wytwarzana była z fałszywego srebra; zob. W. Urban, Gabriel z Przemyśla, sandomierski renesansowy księżyna, prawnik i pieniacz, w: Ludzie - Kościól - Wierzenia. Studia z dziejów kultury i społeczeństwa Europy Środkowej (średniowiecze - wczesna epoka nowożytna), red. W. Iwańczak, S.K. Kuczyński, Warszawa 2001, s. 285-286.

${ }^{42}$ Było to popularne nabożeństwo, którego wczesne celebracje łączone są z XIV-wiecznymi benedyktynami w Turyngii; zob. C. Muessig, The Stigmata in Medieval and Early Modern Europe, Oxford 2020, s. 172.

${ }^{43}$ Zob. M. Derwich, Erem św. Katarzyny pod Lysica i benedyktyni świętokrzyscy, w: Ludzie Kościót-Wierzenia, s. 135-144; M. Szczyglak, Klasztor ojców bernardynów w Świętej Katarzynie, w: Kościót katolicki w Małopolsce w średniowieczu i we wczesnym okresie nowożytnym, red. W. Kowalski, J. Muszyńska, Kielce-Gdańsk 2001, s. 97-113. 
przeznaczył na spłatę długów, pozostałe zaś $50 \mathrm{fl}$. - na „fabrykę” kolegiaty. Wikariówkę, którą wzniósł własnym kosztem, przekazał swemu następcy - oby pamiętał o nim w modlitwie. Stanowcza deklaracja, że wspomnianym domem nie ma dysponować kanonik, może wskazywać na niezbyt kordialne relacje między tymi księżmi ${ }^{44}$.

Paweł Bełdrychowski, wikariusz fundi Szydłówek, przedstawił się w 1594 r. jako oczekujący na spłatę niewielkich sum, należnych głównie od chłopów z tejże wsi. Inne skromne legaty wyliczone przy tej okazji to żywność darowana służącej Annie oraz srebrne łyżki, które współbracia w kapłaństwie mieli obrócić na zakup szat liturgicznych. Sprzęty domowe i ubrania rozdzielił między swego patrona, $\mathrm{tj}$. kanonika szydłowskiej prebendy, oraz kieleckiego wikarego Stanisława ze Zwolenia i wicekustosza Marcina z Siewierza. Dwa lata później tenże Marcin Mdloch przygotował swój bardzo skromny testament $\mathrm{z}$ krótką listą darowizn ${ }^{45}$.

Płynące z testamentów wrażenie, iż skromne życie kolegiackich wikariuszy toczyło się w lokalnym kręgu bliskich, świeckich i duchownych, nie oddaje całej ówczesnej rzeczywistości. Oto bowiem Marcin Mdloch, na majątek którego składały się głównie szaty i należności u kilku osób, swój brewiarz ofiarował Marcinowi Szyszkowskiemu, archidiakonowi zawichojskiemu, kanonikowi krakowskiemu, a w przyszłości biskupowi ${ }^{46}$. Chronologicznie najmłodszy z wykorzystanych tu testamentów to zeznanie kanonika kieleckiego Wojciecha Strzemeskiego z 1602 r., tak jak Szyszkowski związanego bardziej z Krakowem niż z Kielcami ${ }^{47}$. Testament jest świadectwem wyższego poziomu zawodowych i towarzyskich relacji. Spisany został w domu Jakuba Steca, obywatela krakowskiego, gdzie Strzemeski mieszkał, egzekutorami zaś ostatniej woli mianował bpa Bernarda Maciejowskiego oraz trzech bliskich mu kanoników krakowskich. Dokument ten skopiowano do księgi kieleckiego oficjała zapewne ze względu na należności, które polecił wyegzekwować. Krótką listę dłużników otwiera Jan Zbigniew Ossoliński z Ujazdu z sumą 120 zł, zamyka zaś „stara Trelczyna” z Kielc winna mu 8 fl. Natomiast $100 \mathrm{fl}$. w posiadaniu Kiliana Szkota w Chęcinach to - jak można się domyślać - lokata mająca przynieść nieokreślone bliżej zyski. Kanonik dodaje bowiem, że z powodu różnych potrzeb część tej sumy wycofał. Niewielkie sumy

${ }^{44}$ AKMKr, A. Off. 1, k. 150v.-153v. Jeśli można wnioskować cokolwiek na tej podstawie na temat stosunków między wyższym a niższym duchowieństwem parafialnym, to nie byłaby to sytuacja wyjątkowa; por. M. Koczerska, Testament kanonika tarnowskiego i plebana Wszystkich Świętych w Krakowie, w: Ludzie - Kościót - Wierzenia, s. 250.

${ }^{45}$ AKMKr, A. Off. 1, k. 162v.-166.

${ }^{46}$ AKMKr, A. Off. 1, k.166. Zob. też E. Ozorowski, Szyszkowski Marcin h Ostoja, w: Słownik polskich teologów katolickich, red. H.E. Wyczawski, t. 4, Warszawa 1983, s. 296; A. Biedrzycka, R. Kawecki, Szyszkowski Marcin h Ostoja, w: Polski Stownik Biograficzny, t. 50, red. A. Romanowski, Warszawa-Kraków 2014-2015, s. 392-406.

${ }^{47}$ Wojciech Strzemaski (Strzemeski) był dworzaninem Filipa Padniewskiego, który udzielił mu święceń po instalacji na kielecką kanonię w 1590 r. Jego zmarły w 1588 r. brat Jan poprzedził Marcina Szyszkowskiego na probostwie iłżeckim; AKKKr, Akp, sygn.. Reg. C7, k. 126v.; H.E. Wyczawski, Studia nad wewnętrznymi dziejami kościelnymi w Małopolsce na schytku XVI wieku, „Prawo Kanoniczne", 7 (1964) s. 72; Corpus inscriptionum Poloniae, t. 7: Województwo radomskie, z. 1: Radom i Itża wraz z regionem, wyd. W. Kowalski, red. Z. Guldon, Warszawa 1992, nr 1. 
winien był natomiast Ornaszowej w Iłży „za wino” oraz Stanisławowi Szembekowi, rajcy krakowskiemu ${ }^{48}$.

Kilka znanych, wyliczonych tu testamentów wskazuje, że ich autorzy wiedli życie dalekie od luksusu, ale też od permanentnej nędzy ${ }^{49}$. Zarówno ustalenia badawcze poczynione dla innych lat i miejsc, jak też ówczesna publicystyka nie pozostawiają wątpliwości, że los wikariusza był naówczas często nie do pozazdroszczenia. Był on bowiem efektem beneficjalnego systemu rekrutacji i utrzymania duchowieństwa, faktycznej daleko posuniętej emancypacji plebanów spod władzy właściwego biskupa oraz niechęci do wprowadzania jakichkolwiek zmian w tym względzie. Opuszczenie parafii, objęcie nowej czy też powierzenie stałego zastępstwa komendarzowi zgodnie z prawem musiało zostać zaaprobowane przez ordynariusza (lub osoby, którym delegował tę władzę). W praktyce konsensu takiego ordynariusz nie mógł udzielić, przynajmniej w dwu pierwszych sytuacjach, bez wcześniejszej zgody kolatora. Ta była faktycznie decydująca ${ }^{50}$. Lekceważenie starań o aprobatę biskupa ujawniała dopiero wizyta jego wysłannika, choć nie ma śladu wskazującego na jakiekolwiek tego konsekwencje. Nie były to jednak, przynajmniej przed 1597 r., częste sytuacje ${ }^{51}$. Między innymi w Mnichowie pamiętano, że srebrny kielich zabrał poprzedni proboszcz Stanisław Miroński, gdy samowolnie, bez zgody ordynariusza, porzucił to beneficjum dla fary w Ptkanowie ${ }^{52}$.

Są przesłanki, aby sądzić, że objęcie parafii wbrew prawu nie było tajemnicą dla wiernych, a poczynania takie nie były im obojętne. W $1551 \mathrm{r}$. Wojciech Morawicki, według wszelkiego prawdopodobieństwa z Morawicy w powiecie chęcińskim, zarzucił Janowi Przybyszowskiemu, iż na plebanię w Daleszycach zbiegł przed siedmiu laty z klasztoru świętokrzyskiego. Sprawa zapewne nie wyszłaby na jaw, gdyby duchowny w odpowiedzi na oskarżenie nie przystąpił do szarpania powoda za brodę i do rękoczynów ${ }^{53}$. Klasztor ów w tamtych latach był w głębokim kryzysie moralnym i gospodarczym, toteż wolno sądzić, że nie tylko Przybyszowski szukał chleba z dala od Łyśca. Jego współbracia, którzy być może również uciekli spod władzy opata żyjącego z konkubiną, nie dali jednak powodu, aby ich imiona trafiły na karty ksiąg biskupich urzędników ${ }^{54}$.

Brak woli poczynienia choćby skromnych reform umacniała sytuacja społeczno-gospodarcza w drugiej połowie XVI wieku. Wzrostowi areału folwarcznego, a w konsekwencji renty odrobkowej oraz areału uprawnego gospodarstw chłopskich towarzyszyły ograniczenia swobody prawnej i ekonomicznej chłopskiego działania. Świadectwo tego można odnaleźć w wykorzystanych tu aktach oficjała.

${ }^{48}$ Rajca od 1588 do 1603, kiedy zmarł; zob. Z. Noga, Krakowska rada miejska w XVI wieku. Studium o elicie władzy, Kraków 2003, s. 345-346; AKMKr, A. Off. 1, k. 172 v.-174.

${ }^{49}$ Co zgodne jest z obserwacjami D. Główki, Majątek osobisty duchowieństwa katolickiego w Koronie w XVII i XVIII wieku, Warszawa 2004.

${ }^{50}$ Por. Kracik, Prawie wielebni, passim; Chachaj, Bliżej schizmatyków, s. 175-177.

${ }^{51}$ AKMKr, AV Cap 8, s. 18, 20, 61.

${ }^{52}$ AKMKr, AV Cap 8, s. 42.

${ }^{53}$ AKMKr, A. Off. 1, k. 5v.

${ }^{54}$ M. Derwich, Opactwo świętokrzyskie w epoce przedrozbiorowej, w: Klasztor na Świętym Krzyżu w polskiej kulturze narodowej, red. D. Olszewski, R. Gryz, Kielce 2000, s. 58. 
W dniu 8 lutego 1553 r. przed urzędnikiem tym stanął Adam Tworkowicz, wójt z Niestachowa, wsi w parafii Daleszyce biskupów krakowskich ${ }^{55} .26$ stycznia tegoż roku wziął ślub w kościele parafialnym w Brzezinach, wybranką zaś była Katarzyna Zawsdzianka z nieodległej Woli Morawickiej. Po uroczystościach nowo zaślubieni zamierzali przenieść się do Brzezin, jednak plan został oprotestowany przez Wawrzyńca Morawickiego, dziedzicznego właściciela wsi panny młodej. Nalegał on, aby para zamieszkała w jego dobrach, gdy zaś prośby nie przyniosły rezultatu, posunął się do przymusu. Oficjał przywołał „święte prawo”, według którego mąż jest głową związku, a kobieta powinna iść za nim. Nakazał też uwolnić Katarzynę, aby mogła połączyć się z mężem. Stanowisko oficjała zgodne było z prawem kanonicznym, które nie znało przeszkody małżeńskiej braku zgody pana feudalnego i akcentowało nieograniczoną wolność w tym względzie. Wolności małżeństw córek chłopskich broniło też prawo państwowe ${ }^{56}$.

Rosnąca liczba ludności wiejskiej przy limitowaniu wychodźstwa ze wsi powodowała wzrost liczby bezrolnych chłopów. Taki ogólniejszy obraz wsi polskiej owych lat zarysowany jest w literaturze przedmiotu, choć uogólnienie to eliminuje z pola widzenia lokalną specyfikę. Niemniej jednak wypada przyjąć, że wiejski czy miejski wikariat był bardziej stabilną i - być może - dochodową, a także prestiżową formą służby niż praca na folwarku lub u sąsiadów ${ }^{57}$. Relatywnie nieliczna zbiorowość wikariuszy była więc, wolno sądzić, wypadkową emancypacyjnych dążeń części ludności chłopskiej, prawnych ograniczeń w wychodźstwie ze wsi oraz indywidualnych decyzji plebanów skłonnych zatrudnić pomocnika. Dochodowość beneficjum, a w nim na ogół skromnego gospodarstwa plebańskie-

${ }^{55}$ W XV wieku w Niestachowie odnotowano sołectwo, natomiast w 1645 r. - wójtostwo; stale na dwu łanach; S. Inglot, Stan i rozmieszczenie uposażenia biskupstwa krakowskiego w połowie XV wieku. Próba odtworzenia zaginionej części Liber beneficiorum Dlugosza, Lwów 1925, s. 39-40; Inwentarz klucza kieleckiego biskupstwa krakowskiego z 1645 roku, wyd. J. Muszyńska, Kielce 2003, s. 24.

${ }^{56}$ AKMKr, A. Off. 1, k. 27r.; A. Terlikowski, Ograniczenia wolności zawierania malżeństw ludności chtopskiej wynikające ze stosunku poddaństwa $w$ Polsce nowożytnej na tle wybranych krajów europejskich, w: Prawo blisko człowieka: z dziejów prawa rodzinnego i spadkowego. Materiały konferencji zorganizowanej przez Sekcje Historii Państwa i Prawa Towarzystwa Biblioteki Stuchaczów Prawa Uniwersytetu Jagiellońskiego, Kraków 7-8 marca 2007 r., red. M. Mikuła, Kraków 2008, s. 50-53.

${ }^{57}$ Zob. przede wszystkim A. Nowak, Przeobrażenia struktury społecznej ludności wiejskiej w Polsce w okresie panowania systemu folwarczno-pańszczyźnianego (XV-XVIII wieku). Próba ujęcia modelowego, w: Badania nad historia gospodarczo-spoleczna w Polsce (Problemy i metody), Warszawa-Poznań 1978, s. 136-142; A. Izydorczyk-Kamler (Praca najemna na wsi matopolskiej w XVI i pierwszej połowie XVII wieku, „Kwartalnik Historyczny”, 97 (1990) nr 1-2, s. 8, 10, 15) wspomina deficyt robotników rolnych w powiecie sandomierskim oraz politykę szlachty tego województwa zmierzającą do ograniczenia liczby ludzi luźnych. Szerzej taż, Chłopi jako pracownicy najemni na wsi matopolskiej w XVI i w pierwszej połowie XVII wieku, Warszawa 2005, s. 43-51; P. Guzowski, Stan i perspektywy badań nad gospodarstwem chłopskim przełomu średniowiecza i czasów nowożytnych, w: Folwark - wieś - latyfundium. Gospodarstwo wiejskie w Rzeczypospolitej w XVI-XVIII wieku, red. J. Muszyńska, S. Kazusek, J. Pielas, Kielce 2009, s. 9-18, gdzie omówienie ważniejszej literatury. Por. Kracik, Prawie wielebni, s. 35. 
go, była tylko jednym z czynników warunkujących podjęcie takiej decyzji - niekoniecznie najważniejszym.

W dotychczasowych badaniach nad rekrutacją do stanu duchownego zwrócono uwagę, że „miejsc pracy dla duchownych niższego szczebla było mniej, niż wynikało to z rzeczywistych potrzeb duszpasterskich oraz liczby kandydatów na duchownych" 58 . Opinię tę bez zastrzeżeń odnieść można wyłącznie do większych miast $^{59}$. W ciągu XVI stulecia w polskich diecezjach narzekano na brak duchownych w parafiach ${ }^{60}$, choć nie wiadomo, w jakim stopniu problem ten występował w różnych rejonach Małopolski. Badający te zagadnienia przed laty Hieronim Eugeniusz Wyczawski stwierdza, „że duchowieństwa w diecezji krakowskiej (...) wtedy nie brakowało" ${ }^{1}$. Średnia liczba duchownych w parafiach prepozytury kieleckiej, wynosząca ok. 1,80 w 1529 r., 1,58 w 1577 r., oraz 1,75 dwadzieścia lat później, to nieco więcej niż analogiczne szacunki poczynione dla innych terenów obszernej diecezji krakowskiej $\left(1,50-1,65\right.$; zob. tabelę 4) ${ }^{62}$. Brak księży, o którym dyskutowano podczas synodów, mógł hipotetycznie być konsekwencją faktu, iż zbyt mało młodych ludzi wybierało kapłaństwo. Takiemu założeniu zdaje się jednak przeczyć powszechność zjawiska wędrownych księży, wyświęcanych często z powołaniem na fikcyjne tytuły kanoniczne. Założyć wolno więc, że przynajmniej w diecezji krakowskiej istniało wtedy znaczne i niesłabnące zainteresowanie taką karierą. Na interesującym nas terenie zjawisko to poświadcza znikoma liczba duchownych, którzy otrzymali prowizję do parafii, w których zastał ich wizytator -6 , to jest $12,77 \%$ ogółu księży. Sytuacja taka nie była niczym niezwy$\mathrm{kłym}^{63}$.

Jeśli przyjąć, że w prepozyturze kieleckiej istniała potrzeba zatrudnienia większej liczby wikariuszy, to przeszkodą mogły być nie tylko trudności gospodarcze, lecz także brak zainteresowania potencjalnych pracodawców. Niedobór duchowieństwa parafialnego nie wynikał więc wyłącznie z obojętności świeckich kolatorów motywowanej zyskiem lub/i skłonnościami do religijnych nowinek. W szerszej skali sytuacje takie niewątpliwie miały miejsce, ale nie tylko one tłu-

${ }^{58}$ Ksiegi egzaminów do święceń w diecezji krakowskiej z lat 1573-1614, oprac. Z. Pietrzyk, Kraków 1991, s. 10.

${ }^{59}$ Co można stwierdzić w konfrontacji z wynikami obliczeń E. Wiśniowskiego, Parafie $w$ średniowiecznej Polsce. Struktura i funkcje spoteczne, Lublin 2004, s. 142. Zob. też B. Przybyszewski, Krakowskie duchowieństwo parafialne przy końcu średniowiecza, „Folia Historica Cracoviensia”, 2 (1994) s. 31-39.

${ }^{60}$ Zob. szerzej S. Litak, Parafie w Rzeczypospolitej w XVI-XVIII wieku. Struktura, funkcje spoteczno-religijne i edukacyjne, Lublin 2004, s. 126-129.

${ }^{61}$ Wyczawski, Studia nad wewnętrznymi dziejami kościelnymi, s. 56-60, oceniwszy wykazy diakonów przygotowujących się do prezbiteriatu, doszedł do wniosku, że „około 90 nowych księży stawało co roku do pracy w diecezji”, a więc sytuacja nie była zła.

${ }^{62}$ Jest to optymistyczna interpretacja, zakładająca w każdym przypadku rezydencję plebana. Por. Wiśniowski, Liczebność duchowieństwa diecezjalnego, s. 62. Zob. też Chachaj, Bliżej schizmatyków, s. 141.

${ }^{63}$ O tym szerzej Kracik, Prawie wielebni, s. 72-76. Tamże, s. 46 o przynaglaniu przez wizytatorów plebanów do zatrudniania wikarych. 
maczą występowanie nieobsadzonych parafii w diecezji krakowskiej ${ }^{64}$. Stosunki własnościowe na omawianym terenie sprawiły, że prawa patronalne należały tam (z bardzo nielicznymi wyjątkami) do krakowskiego ordynariusza oraz innych przedstawicieli katolickiego duchowieństwa. Była to więc sytuacja inna niż na pozostałych obszarach liczącej ok. 900 parafii diecezji krakowskiej, w której tylko $23 \%$ parafii miało patronat duchowny ${ }^{65}$. Nie było więc tam warunków dla systematycznego propagowania idei reformacyjnych ${ }^{66}$. W 1577 r., a więc w okresie szczytowego rozwoju ruchu reformacyjnego, na terenie prepozytury kalwiniści odprawiali swe nabożeństwa w Bardzie ${ }^{67}$, w pałacowej kaplicy w Kurozwękach ${ }^{68}$ oraz w Grzegorzewicach ${ }^{69}$. Co więcej, źródła wykorzystane dla potrzeb tego opracowania sporadycznie dokumentują przeciwne postawy. Zamiana w $1560 \mathrm{r}$. świątyni parafialnej w Łukowej, w powiecie chęcińskim, na zbór ewangelicki ${ }^{70}$ spowodowała reakcję wspomnianego już Wawrzyńca, piszącego się z pobliskiej Morawicy. Nie tylko opowiedział on o zniszczeniach poczynionych przez nowych gospodarzy tego miejsca, którzy m.in. powyrzucali obrazy i znieśli administrowanie sakramentów ,iuxta veterem sanctorum patrum institutionem" "71. Jako kolator zadeklarował dziesięciny, wraz z zaległymi, jeśli tylko powróci dawny ksiądz. Oficjał zdecydował zainteresować tą sprawą bpa Filipa Padniewskiego, gdy ten tylko zawita do Kielc. Nie wiemy natomiast, czy i w jakim stopniu na niedobór duchownych na prowincji wpływała migracja kleru do większych miast, które teoretycznie oferowały większe dochody, ale gdzie konkurencja była ogromna.

Ocenę długości duszpasterskiego stażu kleru prepozytury kieleckiej umożliwiają akta wizytacji 1597 r. Wymienione tam imiona ordynandów i ich konsekratorów można było skonfrontować z informacjami zawartymi w diecezjalnych

${ }^{64}$ Zob. m.in. W. Urban, Reformacja w życiu wsi małopolskiej, „Kieleckie Studia Historyczne”, [1] (1976) s. 14. Także Kracik (Przeciw reformacji, s. 198) braki obsługi duszpasterskiej przypisuje niedbalstwu i chciwości „katolickiego z reguły dziedzica”.

${ }^{65}$ Kracik, Prawie wielebni, s. 29. Zob. też W. Pałucki, Przynależność własnościowa osad, w: Województwo sandomierskie, s. 91-93; M. Derwich, Materiaty do słownika historyczno-geograficznego dóbr i dochodów dziesięcinnych benedyktyńskiego opactwa św. Krzyża na Łysej Górze do 1819 r., Wrocław 2000, passim; Szady, Prawo patronatu, s. 94.

${ }^{66}$ Urban (Reformacja $w$ życiu wsi, s. 12) stwierdza, że „reformacja nie miała [tam] w zasadzie prawa wstępu".

${ }^{67}$ Za sprawą Jana Sienieńskiego, kasztelana żarnowskiego; AKKKr, Akp, sygn. Reg. C7, k. 128v. H. Kowalska, Jan Sienieński z Pomorzan, h. Dębno, w: Polski Stownik Biograficzny, t. 37, red. E. Rostworowski, Kraków 1996-1997, s. 183-188; Internetowy polski słownik biograficzny, https:/www. ipsb.nina.gov.pl/a/biografia/jan-sienienski-z-pomorzan-h-debno\#disqus (dostęp: 17.09.2020).

${ }^{68}$ AKKKr, Akp, sygn. Reg. C7, k. 126r. Katolickich księży usunął gorliwy ewangelik Krzysztof Lanckoroński, kasztelan małogoski; I. Kaniewska, Lanckoroński (Wodzisławski) Krzysztof h. Zadora, w: Polski Stownik Biograficzny, red. E. Rostworowski, t. 16, Wrocław 1971, s. 443-445; Internetowy Polski Słownik Biograficzny https:/www.ipsb.nina.gov.pl/a/biografia/krzysztof-lanckoronski -h-zadora (dostęp: 17.09.2020).

${ }^{69}$ Sprawcą profanacji miał być Stanisław Ożarowski[?]; AKKKr, Akp, sygn. Reg. C7, k. 127v.

${ }^{70}$ H. M[erczyng], Zbory i senatorowie protestanccy $w$ dawnej Rzeczypospolitej, Warszawa 1904, s. 63-64.

${ }^{71}$ AKMKr, A. Off. 1, k. 93v-94v. 
księgach egzaminów do święceń. Jak wykazano w tabeli 5, 45,84\% plebanów i 50,00\% wikariuszy otrzymało wyższe święcenia nie dalej niż 11 lat od czasu wizytacji, w zdecydowanej zaś mniejszości byli ci, którzy pozostawali kapłanami 12 lat i dłużej. Choć dostępne źródła nie pozwoliły na identyfikację 27,08\% badanej zbiorowości, założyć można, że przeważali w niej ordynowani w latach bliskich Radziwiłłowskiej wizytacji. Byli to według wszelkiego prawdopodobieństwa ludzie młodzi (niższe święcenia otrzymać mógł już czternastolatek ${ }^{72}$ ). Zaryzykować można więc ocenę, że księża z doświadczeniem dłuższym niż dwudziestoletnie byli mniejszością. Pozostawało to w związku z relatywnie krótszym niż obecnie przeciętnym trwaniem życia ludzkiego w tamtych wiekach ${ }^{73}$. Powyższe obserwacje rozmijają się więc $\mathrm{z}$ opinią o przeciętnej czterdziestu lat trwania w kapłaństwie ${ }^{74}$. Brak informacji o personelu parafialnym w kolejnej zachowanej wizytacji z 1610 r. uniemożliwia niestety odpowiedź na pytanie, ilu z księży odnotowanych w parafiach prepozytury kieleckiej za pasterzowania kardynała Jerzego Radziwiłła przebywało tam jeszcze trzynaście lat później. Zdecydowana większość duchownych posiadała świecenia kapłańskie (zob. tabelę 6).

Większość księży pochodziła z diecezji krakowskiej (zob. tabelę 7). Informacje zapisane w 1529 r. w bardzo ograniczonym stopniu służyć mogą analizie pochodzenia terytorialnego duchowieństwa prepozytury kieleckiej. Księga retaksacji nic nie mówi w tym kontekście o wikariuszach, pochodzenie zaś aż trzynastu $(48,15 \%)$ plebanów pozostaje nieznane. Jednak w pozostałych przypadkach wiadomo, że jedynie trzech duchownych trafiło na parafie prepozytury spoza diecezji krakowskiej. Takie proporcje pozostają $\mathrm{w}$ zgodzie z tym, co wiadomo o pochodzeniu ordynandów wyświeconych w latach 1473 i 1475 w tejże diecezji. Spośród 21 kleryków, którzy przyjęli wtedy święcenia w Bodzentynie i Kunowie, aż 19 rekrutowało się z terenu diecezji krakowskiej, w tym 10 z prepozytury kieleckiej. Tylko dwu kandydatów pochodziło $z$ archidiecezji gnieźnieńskiej ${ }^{75}$. Pełniejsze dane z końca stulecia utwierdzają w przekonaniu, że napływ księży z terenów spoza diecezji krakowskiej był stale niewielki. Na ogólną liczbę duchownych, których wizytatorzy zastali w $1597 \mathrm{r}$. w parafiach prepozytury kieleckiej, $70,83 \%$ to mieszkańcy osad w diecezji krakowskiej. Odsetek ten realnie był zapewne jeszcze większy, lecz pochodzenia $18,75 \%$ obecnie nie da się ustalić.

Głównie intuicyjny charakter ma natomiast ocena pochodzenia stanowego badanej zbiorowości, jako że oparta może być tylko na bardzo zawodnym kryterium nazwiska. Choć niektóre nazwiska odmiejscowe, znane z księgi retaksacji beneficjów parafialnych 1529 r. oraz z wizytacji 1597 r., występowały pośród XVI

${ }^{72}$ Kracik, Potrydencki system, s. 480.

${ }^{73}$ Zob. C. Kuklo, Demografia Rzeczypospolitej przedrozbiorowej, Warszawa 2009, s. 416-418, który przeciętną długość ludzkiego życia w tamtych wiekach ocenia na 26-27 lat, jednak szacunek ten uwzględnia wysoką śmiertelność niemowląt i dzieci.

${ }^{74}$ Kracik, Prawie wielebni, s. 38.

${ }^{75}$ K. Kaczmarek, Święcenia duchowieństwa przez biskupa krakowskiego Jana Rzeszowskiego (†1488), „Folia Historica Cracoviensia”, 18 (2012) s. 158-160. 
-wiecznej szlachty województwa sandomierskiego ${ }^{76}$, trudno na tej podstawie o pewność, czy duchowni pochodzili z rodzin właścicieli wsi, czy z zamieszkałych tam rodzin chłopskich, gdyż i to się zdarzało. Jeśli jednak rzeczywiście plebani, a ponadto jeden wikariusz, o nazwiskach: Bębnowski, Borzykowski, Bostowski, Górski, Grabowski, Falibowski, Kuczkowski, Kuczowski, Modliszowski, Ostrowski, Pieniążek, Rajecki, Ruszkowski, Strzemaski, Wolski i Wróblowski ${ }^{77}$, wywodzili się z herbowych rodów, to byłoby to tylko od 12 do $20 \%$ ogółu duchowieństwa kieleckiej prepozytury zarejestrowanego w latach 1529, 1577 i 1597 . Wielkość ta ma jedynie orientacyjny charakter; nie odbiega też istotnie od ustaleń dotyczących całej ogromnej diecezji krakowskiej, w której w latach 1573-1614 tylko $16,40 \%$ ordynandów to synowie szlachty. Źródła wykorzystane dla potrzeb tego opracowania wspierają też obserwacje Stanisława Litaka, który sugerował znaczący wpływ stosunków własnościowych na danym terenie na stanowe pochodzenie duchownych ${ }^{78}$. Swoistym potwierdzeniem tego jest iłżecki prepozyt i kanonik krakowski Marcin Szyszkowski, siostrzeniec starosty iłżeckiego, to jest urzędnika dóbr stołowych krakowskiego ordynariusza, skoligacony z bpem Piotrem Myszkowskim $^{79}$. Pozostałe wymienione tu nazwiska również należą do rodów z dolnych szczebli ówczesnej hierarchii społecznej. Natomiast członkowie kieleckiej kapituły mniejszej to przybysze z miast województwa sandomierskiego czy też okolicznych jak Radomsko lub Siewierz, ale i synowie chłopscy ${ }^{80}$.

Zaangażowanie księży w parafialne duszpasterstwo oceniano przede wszystkim z perspektywy dbałości o majątek Kościoła. Stan budynków był na ogół nienajlepszy; jeśli dobrze utrzymana była świątynia, to remontu wymagały zabudo-

${ }^{76}$ Można stwierdzić to na podstawie Polska XVI wieku pod względem geograficzno-statystycznym, [oprac.] A. Pawiński, t. 3: Małopolska, Warszawa 1886, s. 114-126.

${ }^{77}$ Rody o tych nazwiskach dowodnie wiązać można z Małopolską, tylko zaś niektórzy tacy duchowni jak np. bracia Strzemascy to mazowiecka szlachta; F. Siarczyński, Opis powiatu radomskiego, wyd. T. Lipiński, Warszawa 1847, s. 132; A. Boniecki, Herbarz polski, cz. 1, t. 1, Warszawa 1899 , s. $176-177$; t. 2,1900 , s. 69 , 88; t. 5, 1902 , s. $249-250$; t. 6,1903 , s. $269-270$, 279-281; t. 7 , 1904, s. 24; t. 13, 1909, s. 99-100, 104; K. Niesiecki, Herbarz polski, wyd. J. N. Bobrowicz, t. 6, Lipsk 1841, s. 443-445; t. 7, 1841, s. 202, 289; t. 8, 1841, s. 85, 199-200, 547-550, t. 9, 1842, s. 401, 444-445; H. Stupnicki, Herbarz polski i imionospis zastużonych w Polsce ludzi wszystkich stanów i czasów; ułożony porządkiem alfabetycznym na podstawie Herbarza Niesieckiego i manuskryptów, Lwów 1859, t. 2, s. 77.

${ }^{78}$ Przegląd stanowisk badawczych przedstawił W. Kowalski, Jan Dlugosz a tzw. szlachecki antyklerykalizm w siedemnastowiecznej Rzeczypospolitej, w: Jan Dlugosz - w kręgu badań historyków i literaturoznawców, red. T. Giergiel, Sandomierz 2017, s. 191.

${ }^{79}$ Biedrzycka, Kawecki, Szyszkowski Marcin, s. 393.

${ }^{80}$ Ocena ta sformułowana została na podstawie zapisów w księgach metrykalnych parafii kolegiackiej (zob. przypis 7) oraz protokołu wizytacji Radziwiłłowskiej z 1598 r.; AKMKr, AV Cap 9, s. 482. Przykładowo bracia (?) Stanisław i Paweł Borkowie, członkowie kapituły mniejszej w latach 70. i 80. XVI wieku, pochodzili z biskupiej wsi Radlin nieopodal Kielc; Archiwum Diecezjalne w Kielcach (dalej: ADK), Księgi metrykalne parafii rzymskokatolickiej w Kielcach (Katedra) (dalej: Km), sygn. 100, s. 2, 63, 77, 78. Potwierdzeniem plebejskiego i często miejskiego pochodzenia kieleckich wikariuszy w XVII stuleciu są szczegółowe ustalenia M. Samek (Kielce XVII-XVIII wiek. Stownik biograficzny, Kielce 2003). 
wania parafialne - lub odwrotnie. Krytyka utrzymania zabudowań była częsta, a wizytatorzy nie znaleźli ku temu podstaw jedynie w Daleszycach, Iłży, Kunowie, Wąchocku i we Wzdole. Egzemplifikacją mizernej na ogół kondycji parafialnych domostw mogą być połączone od 1491 r. placówki duszpasterskie w Starej i Nowej Słupi, w dobrach świętokrzyskich benedyktynów ${ }^{81}$. W pierwszej z wymienionych osad tak pokrycie drewnianego kościoła, jak i dzwonnicy oraz kostnicy pozostawiało wiele do życzenia. Cmentarz był nieogrodzony, dom plebański w ruinie, wikariówka zaś zbudowana byle jak. W Nowej Słupi zastano kościół, dzwonnicę i ossarium po części w nienajgorszym stanie. Budynek szkoły i dom wikarego były jednak zrujnowane ze starości, a plebanii nie było w ogóle ${ }^{82}$. Przegniłe dachy drewnianych budynków występowały wówczas nagminnie jako wynik zaniedbań wymiany gontów po zimie ${ }^{83}$. Naszkicowany tu obraz wiejskich czy małomiasteczkowych far zapewne mało kogo raził. Kardynał Jerzy Radziwiłł, który wizytował Kielce od 27 sierpnia do 1 września 1598 r., zastał świątynię kolegiacką i jej otoczenie w opłakanym stanie. Między innymi po nieogrodzonym cmentarzu biegały zwierzęta, domy zaś prałatów, kanoników i ich wikariuszy chyliły się ku upadkowi ze starości. Należy więc zgodzić się z kardynałem, że przynajmniej członkowie kapituły większej - nie mieszkali tam często ${ }^{84}$.

Zaopatrzenie w szaty liturgiczne oraz wyposażenie świątyń nie budziło większych zastrzeżeń wizytatorów tak z końcem XVI, jak i z początkiem XVII wieku. Księgi, o których można przeczytać w powizytacyjnych protokołach, zasługują jednak na bliższą uwagę. Ich obecność była nieodzowna dla poprawnego sprawowania służby Bożej, liczba i treści zaś posiadanych woluminów przybliżają, choćby tylko pobieżnie, horyzonty umysłowe ich czytelników oraz sumienność w realizacji zaleceń synodalnych ${ }^{85}$. Weryfikacja stanu zapisanego w 1597 r. przy pomocy obrazu utrwalonego w kolejnej wizytacji każe wątpić w systematyczny, rzetelny wgląd wysłanników Radziwiłła w stan parafialnych bibliotek. Wysoce wątpliwe jest bowiem, aby niedostrzeżone przez nich „stare”, a więc zapewne w większości średniowieczne księgi, które odnotowano w 1610 r. w Bodzentynie,

\footnotetext{
${ }^{81}$ Derwich, Materiaty do stownika, s. 133-143, 182-186.

${ }^{82}$ AKMKr, AV Cap 8, s. 20-21.

${ }^{83}$ Por. S.K. Olczak, Dachy kościołów parafialnych $w$ archidiakonacie włocławskim $w$ świetle wizytacji z XVII i XVIII wieku, „Almanach Historyczny”, 6 (2004) s. 59-68.

${ }^{84}$ AKMKr, AV Cap 9, s. 480, 488; zob. też J. Garbacik, Wizytacja kolegiaty kieleckiej przez kardynała Jerzego Radziwitła 2 września 1598, „Radostowa”, 3 (1938) s. 64-67. Takie zaniedbania bywały w szerszej skali konsekwencją rozmaitych społecznych funkcji cmentarzy, o czym szerzej zob. P. Ariès, Człowiek i śmierć, Warszawa 1989, s. 73-81.

${ }^{85}$ Tego zdania był także autor pionierskiej pracy w tym zakresie H.E. Wyczawski, Biblioteki parafialne w diecezji krakowskiej u schyłku XVI wieku, „Polonia Sacra”, 6 (1953-1954) nr 1, s. 115. Wyczawski wykorzystał jednak głównie pełniejsze protokoły powizytacyjne z południowych obszarów diecezji. Dają one bardziej wnikliwy obraz księgozbiorów niż analogiczne źródła przedstawiające parafie prepozytury kieleckiej, a ponadto przybliżają prywatne kolekcje księży, których to informacji odnośnie Kielc i okolicy wizytatorzy poskąpili.
} 
Chybicach, Krzyżanowicach, Łagowie, Szumsku, Tarczku, Wąchocku i Zbelutce, trafiły tam wszystkie po 1597 r. (zob. zestawienie 1$)^{86}$.

Porównanie stanu zapisanego w tych latach pokazuje za to konsekwencję, z jaką wprowadzano rzymski porządek celebracji mszy. W 1597 r. mszał rzymski, przejęty dla polskich diecezji przez uczestników synodu piotrkowskiego dwadzieścia lat wcześniej, występował już wszędzie, na ogół jednak w sąsiedztwie starszego diecezjalnego przewodnika liturgicznego ${ }^{87}$. Trzynaście lat później mszał krakowski $^{88}$ napotkano już tylko w pięciu parafiach. Jednak jeszcze u schyłku XVI wieku posiadanie mszału rzymskiego nie zawsze oznaczało, że z niego korzystano. Odnotowana na innych terenach niechęć do posługiwania się rzymskimi rubrykami, w prepozyturze kieleckiej zapisana została expressis verbis w Bodzentynie ${ }^{89}$. Najpewniej nie korzystano z niego też u schyłku wieku w kieleckiej kolegiacie ${ }^{90}$. Kardynał, który wizytował niektóre ośrodki miejskie swej diecezji, korygował liturgię, przypominał, aby nie powtarzać dawnych formuł ${ }^{91}$. Powszechnie odnotowywano też zmodyfikowane agendy: włocławską, przyjętą w 1577 r. dla całej prowincji gnieźnieńskiej, oraz opublikowaną w $1591 \mathrm{r}$. w Krakowie (tzw. Powodowskiego). Nie znaczy to jednak, że całkowicie wyeliminowano formalnie nieakceptowane dłużej rytuały o średniowiecznej metryce. Wydaje się, że mając świadomość kierunku i potrzeby zmian, nie robiono z tego problemu pierwszej wagi. Dawna agenda gnieźnieńska obowiązywała bowiem jeszcze w 1610 r. m.in. w Jastrzębiu, będącym de facto filią Iłży, a prepozyturę w tym mieście obejmowali duchowni blisko związani z krakowskim dworem biskupim. Pamiętać należy jednak również o ograniczeniach finansowych i ogólnie niełatwych początkach produkcji w Polsce zreformowanych ksiąg liturgicznych ${ }^{92}$.

${ }^{86}$ Słuszna jest obserwacja Wyczawskiego (Biblioteki parafialne, s. 118-119, 122-123), że „widać (...) pewien pośpiech”, a ponadto iż zasadniczym celem wizytatorów było śledzenie druków „heretyckich" i literatury pomocnej duszpasterstwu.

${ }^{87}$ Por. T. Długosz, Sprawy liturgiczne w XVI w. w diecezji krakowskiej, „Ruch Biblijny i Liturgiczny, 4 (1951) s. 297-298; S. Koperek, Mszat, w: Encyklopedia katolicka, t. 13, red. E. Gigilewicz, Lublin 2009, kol. 462; N. Nowakowska, From Strassburg to Trent: Bishops, Printing and Liturgical Reform in the Fifteenth Century, „Past and Present”, 213 (2011) s. 7.

${ }^{88}$ Pozostaje niejasne, egzemplarze jakich edycji mszałów drukowanych dla diecezji krakowskiej w XV wieku czy w pierwszej połowie XVI stulecia mieli w rękach wizytatorzy. Wiadomo, że mszały zlecane do druku przez Fryderyka Jagiellończyka czy Jana Konarskiego używane były w diecezji krakowskiej jeszcze w latach 60. XVI stulecia; Długosz, Sprawy liturgiczne, s. 298; Nowakowska, From Strassburg to Trent, s. 26.

${ }^{89}$ Zob. zestawienie 1. Por. Wyczawski, Biblioteki parafialne, s. 162; por. A. Rojewski, Recepcja ksiag liturgicznych soboru trydenckiego $w$ archidiakonacie dobrzyńskim w latach 1597-1609, „Studia Płockie", 7 (1979) s. 189.

${ }^{90}$ A. Kwaśniewski, Księgozbiór kapituły kieleckiej w świetle inwentarza z 1598 r., „Archiwa, Biblioteki i Muzea Kościelne", 99 (2013) s. 57.

${ }^{91}$ AKMKr, AV Cap 9, passim. O tym również Kuśmierczyk, Problematyka listu, s. 252.

${ }^{92} \mathrm{O}$ tym szerzej zob. T. Pietras, Produkcja katolickiej ksią̇ki liturgicznej w Polsce od końca XV do połowy XVII wieku, „Archiwa, Biblioteki i Muzea Kościelne”, 39 (1979) s. 188-189; J. Dyl, Książki teologiczne polskich drukarń XV i XVI wieku, „Archiwa, Biblioteki i Muzea Kościelne”, 69 (1998) s. 101-170. 
Libri sacri, to jest księgi pomocne głoszeniu kazań, wzmiankowane są nieczęsto, jeszcze zaś rzadziej odnotowywano ich tytuły. Wskazują one nie tyle na przemyślany dobór, co raczej na przypadkowe pozyskanie tej czy innej pozycji; kolekcje te liczą prawie bez wyjątku po kilka egzemplarzy (zob. zestawienie 1) ${ }^{93}$. Wizytatorzy z rzadka tylko odnotowują takie dzieła o średniowiecznej metryce. Jak zauważono w Bodzentynie, ze starych ksiąg spisanych dawnym pismem nie ma już pożytku. Nie musiała być to jednak reguła, jako że średniowieczne kodeksy służyły duchownym kieleckiej kolegiaty przez cały XVI wiek ${ }^{94}$. Z nowszych dzieł, które spełniać mogły oczekiwania współczesnych prawodawców organizujących front walki o dusze chrześcijan ${ }^{95}$, spotyka się agendy: gnieźnieńską (rekomendowaną przez Stanisława Karnkowskiego w 1577 r.) oraz Hieronima Powodowskiego, ponadto postyllę Jakuba Wujka, wymienioną jednak tylko w trzech parafiach ${ }^{96}$. Zaskakuje natomiast brak jakichkolwiek wzmianek o katechizmach dedykowanych systematycznej pracy ze świeckimi ${ }^{97}$. Do grupy tej bowiem trudno zaliczyć Confessio Stanisława Hozjusza, popularny w całej Europie podręcznik dogmatyki katolickiej, adresowany jednak przede wszystkim do duchownych, wymieniony zresztą tylko raz (zob. zestawienie 1). Podobnie tylko w jednej parafii odnotowano katechizm rzymski, dostępny w Polsce od 1568 r. w tłumaczeniu Walentego Kuczborskiego ${ }^{98}$. Wizytacje milczą np. o obszernym, lecz przystępnym objaśnieniu podstaw wiary, z którego korzyści płynąć mogły zarówno dla parafialnego duchowieństwa, jak i dla wykształconych świeckich, tj. o Nauce prawego chrześcijanina Benedykta Herbesta (1566) ${ }^{99}$. Niespodziewanie jednak moż-

${ }^{93}$ Wyjątkowa pod tym względem, znacznie bogatsza biblioteka iłżecka zostanie omówiona osobno. Obszerny zbiór kolegiaty kieleckiej przeanalizował Kwaśniewski, Księgozbiór kapituły kieleckiej, s. 43-92.

${ }^{94}$ P. Kardyś, Przyczynki do dziejów księgozbioru Kolegiaty Kieleckiej w średniowieczu i okresie wczesnonowożytnym, „Biuletyn Biblioteki Jagiellońskiej”, 56-57 (2006-2007) s. 24.

${ }^{95}$ Zob. M. Hanusiewicz-Lavallee, Dawne i nowe. Tożsamość wyznaniowa katolików świeckich $w$ potrydenckiej Rzeczypospolitej, w: Formowanie kultury katolickiej w dobie potrydenckiej. Powszechność i narodowość katolicyzmu polskiego, red. J. Dąbkowska-Kujko, Warszawa 2016, s. 130131.

${ }^{96}$ Jednak według Wyczawskiego (Biblioteki parafialne, s. 60) bardzo naówczas popularną.

${ }^{97}$ Por. W. Kowalski, Man and God: The First Three Commandments in the Polish Catholic Catechisms of the 1560s-1570s, w: The Ten Commandments in Medieval and Early Modern Culture, red. Y. Desplenter, J. Pieters, W. Melion, Leiden-Boston 2017, s. 219-238, gdzie starsza literatura.

${ }^{98}$ J.Z. Słowiński, Katechizmy katolickie w języku polskim od XVI do XVIII wieku, Lublin 2005, s. 68; W. Osial, Historia katechizmu. Geneza i rozwój katechizmu w Kościele katolickim od I do XVI wieku, Warszawa 2013, s. 278-296.

${ }^{99}$ Universal Short Title Catalogue (dalej: USTC) 241950. Wielce prawdopodobne jest, że dzieło to nie znalazło powszechnego uznania współczesnych. Przyczyny to zapewne poleganie na tradycji w tych aspektach, które nie zyskały sankcji trydenckich reformatorów oraz brak nauki o sakramentach. Niejasno wypowiada się na ten temat Wyczawski, Biblioteki parafialne, s. 44. „Katechizm soboru trydenckiego", pod którą to nazwą mieści on prace różnych autorów, miał występować w 73 parafiach. Autor ten zalicza doń m.in. wspomniane tu dzieło Herbesta, co pozostaje dyskusyjne. Zob. też Osial, Historia katechizmu, s. 319-326. 
na spotkać jako prywatną własność katechizm niemieckiego franciszkanina Konrada Klinga ${ }^{100}$. Odwiedzający w 1598 r. główne miasta swej diecezji Jerzy Radziwiłł nakazywał księżom, aby co niedziela recytowali z chłopcami mały katechizm ${ }^{101}$, w tygodniu zaś omawiali wybrane fragmenty.

Przeanalizowawszy księgozbiory parafialne i prywatne diecezji krakowskiej u schyłku XVI stulecia, Wyczawski doszedł do wniosku, że zdecydowana większość księży na co dzień poszerzała swą wiedzę teologiczną. Bez lektury druków, będących własnością prywatną czy też beneficjum, nie byłoby możliwe systematyczne głoszenie kazań, a było to - twierdzi Wyczawski - powszechną prakty$\mathrm{ką}^{102}$. Ta optymistyczna wizja dziejów wymaga komentarza. Uwagi poczynione przez wizytatora w Kielcach ${ }^{103}$ czy w Iłży ${ }^{104}$ rzeczywiście wskazują na czytelnictwo wikariuszy. Książki będące na podorędziu wspomnianego już kielczanina Macieja Gila to m.in. „thesaurus novus”. W 1538 r., gdy ów bodzentyński wikary spisywał swój testament, była to rzeczywiście nowa publikacja ${ }^{105}$. Darowizną tą, „una cum panewka pro coquendis piscibus”, wyróżnił bliżej nieznanego Jerzego. Jeśli przyjąć, że testator kierował się znaną skądinąd zasadą szeregowania rzeczy według ich wartości ${ }^{106}$, to byłaby to raczej wartość niematerialna, sentymentalna. Maciej Gil był też właścicielem mszału Tomickiego ${ }^{107}$, bliżej nieokreślonego dzieła traktującego o Męce Pańskiej, poczytnego hortulusa ${ }^{108}$, brewiarza ${ }^{109}$, skró-

${ }^{100}$ K. Kling, Catechismus catholicus, Kolonia 1562, USTC 640936. Werner, Cling, Konrad, w: Allgemeine Deutsche Biographie, vol. 4, Berlin 1876, s. 333-334; H.-C. Rickauer, Rechtfertigung und Heil. Die Vermittlung von Glaube und Heilshandeln in der Auseinandersetzung mit der reformatorischen Lehre bei Konrad Klinge (1483/84-1556), Leipzig 1986.

${ }^{101}$ Zapewne Kanizjusza; zob. Słowiński, Katechizmy katolickie, s. 62-64; Osial, Historia katechizmu, s. 277-278.

${ }^{102}$ Wyczawski, Biblioteki parafialne, s. 122, 138; tenże, Studia, s. 105, 108-110, 169.

103 „Nie należy wydawać książek z biblioteki duchownym zanim wicekustosz nie wpisze wypożyczeń do specjalnego rejestru'; AKMKr, AV Cap 9, s. 492.

${ }^{104} \mathrm{~W} 1610$ r. poinformowano wizytatora, że księgi parafialnej biblioteki są w większości w domach duchownych. Ci zaś są nieobecni, więc nie można sporządzić rejestru; AKMKr, AV Cap 30, k. $12 \mathrm{r}$

${ }^{105}$ Wymienił bowiem albo pierwsze wydanie Sermones de tempore, inscripti thesaurus novus, Piotra de Palude, które w 1536 r. opublikowała kolońska oficyna Melchiora von Neuß (USTC 693617) lub o rok późniejszą anonimową kolekcję Sermones de sanctis inscripti thesaurus novus, ogłoszoną w Paryżu przez Jana Petit (USTC 182218). Paludanus OP (1278-1342) to teolog, patriarcha Jerozolimy. Atrybucja wymienionych tu zbiorów kazań pozostaje dyskusyjna. Por. J. Dunbabin, A Hound of God: Pierre de la Palud and the Fourteenth-Century Church, Oxford 1991.

${ }^{106}$ Por. A. Pośpiech, Pułapka oczywistości. Pośmiertne spisy ruchomości szlachty wielkopolskiej z XVII wieku, Warszawa 1992, s. 81.

${ }^{107}$ Missale Secundum Ritum Insignis Ecclesie Cathedralis Cracoviensis Noviter Emendatum, Venetiis 1532; zob. Długosz, Sprawy liturgiczne, s. 298.

${ }^{108}$ Jedna z licznie krążących po Europie wersji „ogrodu dusznego”, być może Meffreta, Sermones de tempore et de sanctis, sive Hortulus regince, Bazylea, przed 1483, lub późniejsze edycje (USTC 747148), lub np. Raj duszny Biernata z Lublina (1513); zob. T. Michałowska, Średniowiecze, Warszawa 1995, s. 640.

${ }^{109}$ Tak zapewne należy rozumieć określenie „viaticum parvuum” (brewiarz podróżny?); por. Acta capitulorum nec non iudiciorum ecclesiasticorum selecta, vol. 2: Acta iudiciorum ecclesiasti- 
conego brewiarza (diurnale), nieokreślonej bliżej postylli oraz Biblii ${ }^{110}$. Własnoręcznie spisywał też (kopiował?) kazania „tam de sanctis, quam de tempore”. Ten zapis, choć unikatowy na terenie prepozytury kieleckiej, jest świadectwem częstszej praktyki ${ }^{111}$.

Podobnie prodziekan kielecki, Stanisław Dźwig z Bodzentyna, przedstawił się w swym testamencie (1574 r.) jako właściciel hortulusa, dwu brewiarzy, z których jeden polecił zwrócić kościołowi jako jego własność. W samokształceniu przed wejściem na ambonę mogły być pomocne Lexicon biblicum ${ }^{112}$ oraz humanistyczny katechizm Nowopolczyka ${ }^{113}$. Tę skromną listę ksiąg zamykają Kroniki Marcina Kromera ${ }^{114}$. Skądinąd wiadomo, że był też właścicielem popularnego podręcznika teologii fundamentalnej pióra augustianina Jana Hofmeistera ${ }^{115}$, zbioru kazań benedyktyna Heimo z Saint-Germain d'Auxerre ${ }^{116}$, komentarzy do Nowego Testamentu Teofilakta z Ochrydy w thumaczeniu Jana Ekolampada, jednego $\mathrm{z}$ czołowych reformatorów ${ }^{117}$, a ponadto fragmentu zbioru kazań flamandzkiego teologa i humanisty Josse van Clichtove, przeciwnika m.in. Lutra i Ekolampada, głoszącego poglądy o konieczności reformy życia kleru ${ }^{118}$.

W ostatniej woli spisanej w 1594 r. wikariusz kielecki Paweł Beldrychowski polecił przekazać swej kolegiacie bliżej nieokreślone książki teologiczne, które zostaną znalezione po jego śmierci. Imiennie wskazanym braciom w kapłaństwie darował natomiast brewiarz oraz diurnalik, tj. brewiarz z godzinami kanonicznymi. Po śmierci kanonika Erazma zatrzymał biblię i konkordancję biblijną, które -

corum dioecesum Gneznensis et Poznaniensis (1403-1530), wyd. B. Ulanowski, Kraków 1902, nr 1685; USTC 240536 i 121635.

${ }^{110}$ AKMKr, A. Off. 1, k. 12-12v.

${ }^{111}$ Zob. Wyczawski, Studia, s. 110.

112 A. Placus, Lexicon biblicum, sacrce philosophice candidatis elaboratum, Kolonia 1536 (USTC 671847). Andreas Placus był niemieckim franciszkaninem i znany jest głównie jako autor tego zbioru komentarzy; A. Chacón i in., Bibliotheca libros et scriptores ferme cunctos ab initio mundi ad annum MDLXXXIII, Parisiis 1731, kol. 156-157.

${ }^{113}$ Apologia pro catholica fide et doctrina de veritate corporis Christi Jesu in Eucharistia, de caterisque sacramentis: liturgice item seu Missa sacrificio, Kraków 1559 (USTC 240069). Zob. J. Tyrawa, Nowopolczyk, Nowopolski, Novicampianus Wojciech, w: Encyklopedia katolicka, t. 14, red. E. Gigilewicz, Lublin 2010, kol. 77.

114 Por. A. Małecki, „Historyków nie zaniechaj czytać...”: studia nad twórczościa historyczna Marcina Kromera i jej renesansowa recepcja, Poznań 2013. AKMKr, A. Off. 1, k. 135r-135v.

${ }^{115}$ Pozycję tę, ogłoszoną po raz pierwszy w 1547 r., wymienia A. Kwaśniewski, Księgozbiory prywatne zachowane w bibliotece kapituły kieleckiej (XV-XVIII wiek), „Biuletyn Biblioteki Jagiellońskiej”, 62 (2012) s. 75. O autorze (1509/10-1547) zob. A. Zumkeller, Hoffmeister, Johannes, w: Neue Deutsche Biographie, t. 9, Berlin 1972, s. 441.

${ }_{116}$ Żył w IX w.; Repertorium biblicum medii aevi, t. 3: Commentaria, red. F. Stegmüller, Matritii 1981, s. 7-8. Dwa tomy drukowane w 1537 r.; zob. Kwaśniewski, Księgozbiory prywatne, s. 75.

${ }^{117}$ Edycja kolońska z 1541 r. nieznana USTC; za Kwaśniewskim, Księgozbiory prywatne, s. 75. O autorze żyjącym na przełomie XI i XX wieku zob. B. Modzelewska, Teofilakt z Ochrydy, w: Encyklopedia katolicka, t. 19, red. E. Gigilewicz, Lublin 2013, kol. 649.

${ }^{118}$ Kwaśniewski, Księgozbiory prywatne, s. 75. J.-P. Massaut, Josse Clichtove, l'humanisme et la réforme du clergé, vol. 1-2, Paris 1968. 
jak wyjaśnił - były własnością kościoła w Daleszycach i tam powinny wrócić. Był ponadto właścicielem bliżej nieokreślonych „libri prophani”. Ich środowiskowa wartość była chyba niższa, gdyż pozwolił egzekutorom testamentu dysponować nimi wedle uznania ${ }^{119}$.

Tę krótką prezentację prywatnych zasobów bibliotecznych wikariuszy związanych z kielecką kolegiatą można by rozszerzyć o kilka skądinąd znanych nazwisk, jak m.in. oficjałów Macieja z Końskich i Floriana Piltowskiego. Takim bibliofilem był też zmarły w 1558 r. Marcin z Kielc, właściciel m.in. komentarza biblijnego wydanego wraz z antytalmudystyczną polemiką słynnego franciszkanina Mikołaja z Lyry (ok. 1270-1349) ${ }^{120}$. Wszystkie te obserwacje potwierdzają dotychczasowe ustalenia, iż prywatne kolekcje wikariuszy liczyły na ogół kilka, sporadycznie kilkanaście tomów, a dominowały dzieła użyteczne w praktyce duszpasterskiej ${ }^{121}$. Przypadkowość tych zbiorów, powiększanych powszechnie nie tylko drogą kupna, ale i przez dziedziczenie czy okresowe przywłaszczenie, nie ulega wątpliwości. Podkreślić trzeba, że chodzi tu o elitę niższego duchowieństwa, wikarych o według wszelkiego prawdopodobieństwa relatywnie największych, stałych dochodach i takich kontaktach z Krakowem. Przyjąć też można jako pewne, że posiadanie nawet nielicznych ksiąg było powodem do dumy szczególnie że wikariusze wywodzili się z tych kręgów społecznych, w których czytelnictwo było nieczęste ${ }^{122}$. Mogło dawać poczucie więzi intelektualnej z elitą, środowiskiem kanoników i prałatów, którzy posiadali znacznie obszerniejsze kolekcje ksiąg, a które legowali, bywało, kolegiacie ${ }^{123}$.

Tak często podkreślana w dotychczasowej literaturze konieczność posiadania choćby pojedynczych tomów homilii dla sukcesów coniedzielnego kaznodziejstwa jest zbyt pochopnym uogólnieniem. W ostatnich dekadach XVI stulecia, kie-

${ }^{119}$ AKMKr, A. Off. 1, k. 163v-164v. Wyczawski (Biblioteki parafialne, s. 67) podkreśla, że literatura świecka była w bibliotekach parafialnych rzadkością, jako że duchowni „nie odczuwali potrzeby jej posiadania".

${ }^{120}$ Za Kwaśniewskim, Księgozbiory prywatne, passim; ponadto Kardyś, Przyczynki do dziejów, s. 33-36. Biblia latina, cum postillis Nicolai de Lyra (...). Nicolaus de Lyra: Contra perfidiam Judaeorum, Norymberga 1493 (USTC 740098). Zob. E.A. Gosselin, A Listing of the Printed Editions of Nicolaus de Lyra, „Traditio”, 26 (1970) s. 409; D. Copeland Klepper, The Insight of Unbelievers. Nicholas of Lyra and Christian Reading of Jewish Text in the Later Middle Ages, Philadelphia 2007.

${ }^{121}$ Wyczawski, Biblioteki parafialne, passim; Kwaśniewski, Księgozbiory prywatne, s. 92 i passim.

${ }^{122}$ Zob. K. Justyniarska-Chojak, Książki w mieszczańskich inwentarzach pośmiertnych z terenu Małopolski (XVI-XVII wiek), w: Historia magistra vitae est... Studia z dziejów społeczno-politycznych, gospodarczych i kulturalnych. Ksiega jubileuszowa dedykowana prof. zw. dr. hab. Wiestawowi Cabanowi z okazji 45-lecia pracy zawodowej, red. L. Michalska-Bracha, M. Przeniosło, B. Wojciechowska, Kielce 2016, s. 57-66. Relatywnie nieliczne zapisy ksiąg w testamentach duchownych odnotował także Wood (The Ownership of Books, s. 107-198). Zakłada on, że część takich prywatnych księgozbiorów darczyńcy przekazali za życia, a także iż liczni duchowni w ogóle nie pozostawili testamentów. Tłumaczenie to odnieść wypada też do kleru prepozytury kieleckiej.

${ }^{123}$ A. Kwaśniewski, Księgozbiór kanonika kieleckiego Wojciecha Strzemeskiego (†1602 r.) w świetle inwentarza z 1650 roku, „Rocznik Kolbuszowski”, 12 (2012) s. 87-107. 
dy to biblioteka kolegiacka liczyła przynajmniej 114 tomów ${ }^{124}$, miejscowi wikariusze obejmowali opieką duszpasterską tylko znikomą część parafialnej społeczności. W latach 1565-1600 pobłogosławili oni 393 pary, czyli średnio 11 rocznie. Był to najpewniej po części efekt odziedziczonego po wcześniejszych wiekach zwyczaju zawierania małżeństw poza Kościołem. Większe liczby wpisów dokumentujące sakrament chrztu pojawiają się dopiero w 1593 r., przy czym do 1598 r. odnotowano 226 takich uroczystości, czyli średnio 53 rocznie. Księgi metrykalne, z których pochodzą te dane, zaświadczają zarówno o lukach w dokumentacji, jak i o poważnych zaniedbaniach na polu duszpasterstwa. Pokazują ponadto, że duchowni kolegiaccy miewali problemy z językiem Rzymian na poziomie podstawowym. Każe to zastanowić się nad praktycznym wykorzystaniem w kazaniach w większości łacińskich tekstów ze wspomnianej bogatej biblioteki. W 1540 r. do parafii kolegiackiej, według wszelkiego prawdopodobieństwa najludniejszej w prepozyturze, należały 22 wsie, wizytacja Radziwiłłowska wspomina 25 osad, liczba zaś wiernych w pierwszej dekadzie XVII wieku szacowana jest na ok. 5500. Jerzy Radziwiłł oraz towarzyszący mu urzędnicy jasno stwierdzili zarówno niedbałe prowadzenie metryk, jak i brak wiedzy wikariuszy o ich parafianach ${ }^{125}$. Poza kontrolą źródłową pozostaje natomiast realna frekwencja wiernych na niedzielnych nabożeństwach oraz odnoszone przez nich korzyści z uczestnictwa w mszach ${ }^{126}$.

Uwagi powizytacyjne Jerzego Radziwiłła to lista uchybień prawu Bożemu oraz wskazań, jak wejść na drogę do zbawienia. Katalog ten powtarzany był z niewielkimi tylko modyfikacjami we wszystkich miastach prepozytury, które odwiedził hierarcha. Ogłaszanie tych samych zaleceń było zapewne wynikiem przekonania, że karczma, cielesne uciechy oraz magia deprawują w każdym miejscu, na dociekanie zaś, jak dalece moralne zepsucie ma miejsce lokalnie, nie było czasu. Zalecenia po wizycie w Kielcach wyróżnia ponadprzeciętne napiętnowanie zaniedbań duchownych ${ }^{127}$. Wydaje się, że w mieście tym na długo przed wizytacją istniało swoiste porozumienie ponad podziałami stanowymi względem omijania prawa kosztem wyborów moralnych. W dniu 12 lipca 1555 r. Elżbieta Królewna z Kielc złożyła przed oficjałem przysięgę na Krzyż, że jej córka Anna spłodzona została przez wikariusza Macieja. Jednocześnie zgodził się on wypłacić 6 grzywien alimentów, a ponadto kwartalnie po ćwierć grzywny. 7 stycznia kolejnego roku Elżbieta zeznała, że otrzymała 1 grzywnę , ratione ablactationis pueri” 128 . Nie jest to jedyny taki wpis w aktach oficjała kieleckiego drugiej połowy XVI stulecia. Ten zaś wybrano jako ilustrację, dotyczy bowiem lokalnego wicescholastyka. Godne podkreślenia jest, że materialne zabezpieczenie dziecka i matki

${ }^{124}$ Kwaśniewski, Księgozbiór kapituły, s. 43-92.

${ }^{125}$ Szczegółowe uzasadnienie przywołanych tu danych oraz płynących z nich wniosków, a także obszerna literatura zob. Kowalski, Trydenckie wyzwania.

${ }^{126}$ Por. S. Bylina, Chrystianizacja wsi polskiej u schyłku średniowiecza, Warszawa 2002, s. 1545; I. Skierska, Obowiązek mszalny w średniowiecznej Polsce, Warszawa 2003, s. 78-80.

${ }^{127}$ Garbacik, Wizytacja kolegiaty, s. 4-6; AKMKr, AV 2, k. 14 r-14v.; AV Cap 9, s. 493, 501-502.

128 To jest ze względu na niemowlęctwo lub też odstawienie od piersi; AKMKr, A. Off. 1, k. 56r-56v., 61v. 
przez ojca prezbitera nie zostało skomentowane w aktach jako wykroczenie. Brak też informacji o jakichkolwiek karach, czy choćby o skierowaniu sprawy do ordynariusza. Ewentualna faktyczna tolerancja dla takiej prywatnej sfery życia duchownych mogła wynikać z nierzadkiego wchodzenia w podobne nieformalne związki ${ }^{129}$.

Książę aktywizował duchownych oraz świeckich prośbą i groźbą. Wykorzystując swą władzę dominialną, nakazał, aby specjalnie ustanowieni w mieście i po wsiach punktatorzy donosili kieleckiemu staroście, czy wszyscy udają się w niedzielę do kościoła. Urzędnik ten, szlachcic reprezentujący biskupa, miał tradycyjnie władzę absolutną w podległym mu kluczu dóbr ${ }^{130}$. Aktywizacja duchowieństwa to przede wszystkim wyjście do świeckich, których wspomagać trzeba „,conversatione, sermone et scientia”. Ci nie mogą umierać bez sakramentów: chrztu, pokuty, namaszczenia chorych i Eucharystii ${ }^{131}$; można więc podejrzewać, że przypadki takie miały miejsce. Jednym $\mathrm{z}$ dyskutowanych zagadnień było, czy jutrznia nie jest odprawiana, gdyż - jak przekonywali duchowni - spiesząc do pracy, lud nie wstąpi do świątyni, czy też - jak twierdzili ich przełożeni - ludzie nie przychodzą, gdyż nabożeństwo nie jest celebrowane. Ojcowie odpowiedzialni są za wychowanie religijne krewnych i służby. Mają wskazywać różnice między dobrem a złem oraz dbać, aby wszyscy uczestniczyli w niedzielnych naukach katechizmowych. $Z$ lat 1581-1582 pochodzą zapisy w metryce kieleckiej kolegiaty, z których wynika, że świeckich z dobrym skutkiem egzaminowano ze znajomości podstawowych prawd wiary ${ }^{132}$. Kardynał Radziwiłł pouczał, iż jeśli księża są zapraszani do domów mieszczan, to niech wykorzystują takie spotkania na edukację wiernych, lecz niech nie przeciągają wizyt od śniadania do kolacji. Kazanie nie powinno trwać ponad godzinę i nie wolno obrażać słuchaczy ${ }^{133}$.

${ }^{129}$ Być może, tak jak we Włoszech, sądy kościelne w ówczesnej Polsce nie interesowały się takimi związkami, jeśli były one wynikiem wzajemnego przyzwolenia; zob. R. Cossar, Clerical „Concubines” in Northern Italy during the Fourteenth Century, ,Journal of Women's History”, 23 (2011) s. 111; por. A. Jabłońska, Obraz duchowieństwa parafialnego w świetle wizytacji Wincentego de Seve (1608-1609) - wybrane aspekty, „Roczniki Humanistyczne”, 65 (2017) nr 2: Historia, s. 1517. W odniesieniu do Polski zagadnienie konkubinatu duchownych jest słabo zbadane i znane jest w zasadzie wyłącznie od strony litery prawa; zob. A. Krawiec, Seksualność w średniowiecznej Polsce, Poznań 2000, s. 111-128; K. Szczygielski, Problematyka konkubinatu w uchwałach soborów powszechnych XII-XVI wieku, w: Miscellanea historico-iuridica, t. 4, red. A. Lityński, P. Fiedorczyk, Białystok 2006, s. 41-57.

${ }^{130}$ J. Szanser, Ustrój miasta Kielc na przełomie XVI i XVII wieku, ,Rocznik Muzeum Narodowego w Kielcach", 12 (1982) s. 28-29. Por. T. Wiślicz, Shepherds of the Catholic Flock: Polish Parochial Clergy, Popular Religion, and the Reception of the Council of Trent, w: Gelehrte Geistlichkeit - geistliche Gelehrte. Beiträge zur Geschichte des Bürgertumsin der Frühneuzeit, red. L. Schorn-Schütte, Berlin 2012, s. 28-29.

${ }^{131}$ AKMKr, AV Cap 9, s. 497, 518.

${ }^{132}$ Kowalski, Trydenckie wyzwania.

${ }^{133}$ Napomnienia takie mają średniowieczną metrykę; zob. K. Bracha, Nauczanie kaznodziejskie $w$ Polsce późnego średniowiecza. Sermones dominicales et festivales z tzw. kolekcji Piotra z Miłosławia, Kielce 2007, s. 109-114. Wszystkie te zalecenia utrzymane były w duchu listu pasterskiego kardynała z 1593 r.; zob. Kuśmierczyk, Problematyka, passim. 
Nawet jeśli duchowni głosili systematycznie kazania, co jest poza weryfikacją źródłową, to bez wątpienia pierwszeństwo miała katechizacja ${ }^{134}$. Rudymentarne informacje z zakresu wiedzy o sakramentach, zawarte w formie wzorcowych kazań w wyliczonych wyżej kompendiach liturgicznych ${ }^{135}$, pozwalają domyślać się, że homilie tej treści uzupełniały katechizmowe podstawy. Erudycja oparta na przypadkowo pozyskanym czy zakupionym tomie kazań zapewne na ogół wystarczyła, aby olśnić intelektem zebranych w kościele. Niekoniecznie jednak musiało się to przekładać na lepszą jakość nauczania oraz większy prestiż wśród wiernych. Znamienny jest tu przykład pochodzący z graniczącej z prepozyturą kielecką parafii Drugnia, w dekanacie Kije prepozytury wiślickiej. Stanisław z nieodległej Podstoły, miejscowy pleban w 1565 r., wspomagał się przy układaniu kazań „starożytnym” brewiarzem. Tłumaczył, że parafianie, wyłącznie okoliczni chłopi, do których należy zwracać się w prosty, niewyszukany sposób, zadowoleni są z jego nauk. Od pięćdziesięciu z nich, zamieszkałych w trzech królewskich wsiach, w których nie było żadnego szlachcica, odebrał wyznanie wiary katolickiej. Ponad osiemdziesięcioletni ksiądz nie posiadał Biblii ani homiliarza i nie starał się o nie ze względu na słaby wzrok. W pracy duszpasterskiej wspomagał go jedynie rektor szkoły ${ }^{136}$.

Postulowana przez kardynała aktywizacja duszpasterstwa miała dokonać się także z pomocą bractw. Siostry i braci zachęcano, aby nie poprzestawali na uczestnictwie w liturgii, mszach żałobnych i innych rutynowych działaniach, których ślady można odnaleźć w wizytacjach. Powinni natomiast - głosił książę - dawać świadectwo gorliwej wiary - m.in. spowiadając się pięć razy do roku oraz odwiedzając co tydzień ubogich w szpitalu ${ }^{137}$. Kardynał Radziwiłł i jego delegaci odnotowali bractwa tylko w nieco ponad $20 \%$ parafii, jednak nie wszędzie były aktywne ${ }^{138}$. W 1610 r. informacje o bractwach można znaleźć już w opisach 22 kościołów

${ }^{134}$ Istniały zresztą po temu wieloletnie tradycje; zob. przede wszystkim Bylina, Chrystianizacja wsi polskiej, s. 46-66; Skierska, Obowiazek mszalny, s. 176-182; K. Bracha, Commentaries on the Decalogue in the Late Middle Ages: Between Method and Catechesis. Poland in the European Context, w: Glossce - Scholia - Commentarii. Studies on Commenting Texts in Antiquity and Middle Ages, red. M. Mejor, K. Jażdżewska, A. Zajchowska, Frankfurt am Main 2014, s. 183-190; K. Bracha, M. Leńczuk, Stowo-Pismo-Sacrum. Cztery studia z dziejów kultury religijnej w Polsce późnego średniowiecza, Warszawa 2020, s. 17-55. Por. Kuśmierczyk, Problematyka, s. 237; Jabłońska, Obraz duchowieństwa, s. 13.

${ }^{135} \mathrm{O}$ tym szerzej zob. M.A. Korzo, Wzory kazań w skladzie agend. Przyczynek do reformy katolickiej w Rzeczypospolitej drugiej połowy XVI wieku, w: Z historii kultury staropolskiej. Studia ofiarowane Urszuli Augustyniak, red. A. Bartoszewicz, A. Karpiński, M. Ptaszyński, A. Zakrzewski, Warszawa 2020, s. 235-244.

${ }^{136}$ AKMKr, AV Cap 1, s. 124-125.

${ }^{137}$ AKMKr, AV Cap 9, s. 549. Choć zachęcano do częstej spowiedzi, niewielu przystępowało do tego sakramentu częściej niż raz w roku; zob. Z. Zalewski, Pobożność eucharystyczna, jej cechy i charakter, „Ruch Biblijny i Liturgiczny”, 39 (1986) z. 4, s. 307-310; Skierska, Obowiazek mszalny, s. 221-250.

${ }^{138}$ Jest to więc sytuacja podobna do zastanej w sąsiednim archidiakonacie lubelskim (26\% parafii z bractwami); zob. J. Flaga, Bractwa religijne w archidiakonacie lubelskim do początków XVII wieku (1604), „Roczniki Humanistyczne”, 21 (1973) s. 151-152. 
(81\%), lecz aktywność tych wspólnot poświadczona jest tylko dla 11 parafii (41\%). Choć w ciągu dwunastu lat dzielących obie wizytacje udało się gdzieniegdzie reanimować te stowarzyszenia czy powołać nowe, parafie prepozytury kieleckiej, w których bracia aktywnie uczestniczyli w lokalnym życiu liturgicznym, to nie więcej niż $25 \%$ (zob. zestawienie 2). O ile więc można przyjąć, że lokalnie bractwa odgrywać mogły istotniejszą rolę w ożywieniu dewocji świeckich i ich pasterzy, to w skali całej prepozytury ich doniosłość była raczej niewielka ${ }^{139}$. Jak widać, akcyjność wynikająca z woli pełniejszego związania z wiarą i Kościołem choćby części trzódki z trudem zyskiwała zrozumienie. Być może dlatego decydowano się nań raczej nieczęsto.

Innym, znacznie częściej odnotowywanym świadectwem udziału wspólnoty w liturgii lokalnego Kościoła jest składanie ofiar pieniężnych na zakup wina, wosku i mąki (do wypieku komunikantów). Doniosłość tego powszechnego w Królestwie zwyczaju objaśniano w kazaniach ${ }^{140}$. Rzadko więc odnotowywano praktyki, jak np. w Krzyżanowicach, że chleb i wino dostarcza sam pleban, lub jak w Kunowie, gdzie pleban dawał chleb, wino zaś kupowano $\mathrm{z}$ ofiar ${ }^{141}$. Odosobnione jest natomiast lokalne świadectwo kultu, który łączył pokolenia wiernych, a w konsekwencji też ich pasterzy. Wizytatorowi, który w 1597 r. odwiedził Świętomarz, pokazano informację o rozpoczętej w $1367 \mathrm{r}$. budowie świątyni zapisaną w starym krakowskim mszale pod 1434 r. Zarówno ten wpis, jak i powtórzenie go w powizytacyjnym protokole jednoznacznie wskazują na żywą pobożność maryjną, zaakcentowaną wezwaniem kościoła. Niewykluczone, że z tego samego źródła czerpał Jan Długosz. Informację tę można odnaleźć bowiem także w jego księdze beneficjów, choć oba warianty akcentują różne aspekty nabożeństwa; Liber beneficiorum jego odwieczność ${ }^{142}$, wizytacja zaś - narodowy charakter ${ }^{143}$. Nieliczne znane obecnie potwierdzenia łask otrzymanych $\mathrm{w}$ jasnogórskim sanktuarium przez pielgrzymów z miast i wsi prepozytury były zapewne żywo komentowane w środowiskach tych pątników ${ }^{144}$.

${ }_{139}$ Por. J. Flaga, Bractwa religijne w Rzeczypospolitej w XVII i XVIII wieku, Lublin 2004, s. 242-244; Wiślicz, Shepherds of the Catholic Flock, s. 34-37.

${ }^{140}$ Szerzej o tym Sczaniecki, Stużba Boża, s. 123-139; Offertorium, w: Leksykon liturgii, oprac. B. Nadolski, Poznań 2006, s. 1075-1083.

${ }^{141}$ Na ogół jak w Iłży: „Panis et vinum ex publica elemosina parochianorum”; AKMKr, AV Cap 8, s. $28,30,35$.

${ }^{142},[--]$ villa Szwyanthamarza denominationem accepit a vulgo, quod ruditer in primordis fidei gloriosam Virginem Szwyanthamarza appellabant."; Joannis Dlugossii senioris canonici Cracoviensis Opera omnia, vol. 8, Liber beneficiorum dioecesis Cracoviensis, t. 2, Ecclesice parochiales, red. A. Przezdziecki, Cracoviæ 1864, s. 462.

${ }^{143}$, ,-- ] sumpsit cognomen villa hæc ex eo, quod Poloni in cordis fidei Christianæ BMV Swiatamarza appellabant.”; AKMKr, AV Cap 65, k. 510. Zob. też S. Trawkowski, Ku odległym poczatkom i dawnym dziejom Bodzentyna, w: Bodzentyn. Z dziejów miasta w XII-XX wieku, red. K. Bracha, Kielce 1998, s. 14-16.

${ }^{144}$ W 1549 r. zapisano świadectwo Andrzeja z Bodzentyna, w 1550 r. - Doroty z Iłży, w 1575 r. Stanisława z Wąchocka oraz żony i córki Stanisława z podkieleckiego Niewachlowa w 1598 r.; A. Witkowska, Kult jasnogórski w formach pątniczych do połowy XVII wieku, „Studia Claromontana", 5 (1984) s. 214-219, tabela 2. 
Gdy porówna się program pracy duszpasterskiej, jej cele oraz problemy stojące na drodze do ich realizacji nakreślone w XIV-XV stuleciu oraz u schyłku XVI wieku, to brak między nimi różnic ${ }^{145}$. Jeśli natomiast spojrzeć na te zagadnienia z perspektywy duchowieństwa małych miast i wsi, to tzw. reforma trydencka zredukowana zostaje do konieczności zakupu mszału rzymskiego i przywyknięcia doń, co na badanym obszarze dopełniło się na przełomie stuleci. W 1597 r. ochrzczonych i zaślubionych spisywano w większości parafii $(67 \%)^{146}$. Duchowni, którzy informowali o tym wizytatora, to najczęściej ludzie młodzi lub w sile wieku i, jak dawniej, w większości z małych miast i wsi Małopolski. Według wszelkiego prawdopodobieństwa większość z nich zyskała niezbędne przygotowanie $\mathrm{w}$ szkole parafialnej, a następnie praktykując u własnego proboszcza. Związki z uniwersytetem krakowskim poświadczone są najwyżej dla ok. 15\% badanej zbiorowości ${ }^{147}$. Choć nie bez szans na poszerzanie horyzontów intelektualnych poprzez indywidualną lekturę, wiejski pasterz mógł dowieść swej skuteczności w codziennym działaniu przede wszystkim dzięki znajomość środowiska, w którym przyszło mu żyć. Wykraczanie poza rudymenty, jeśli w ogóle możliwe, było zapewne wielce ryzykowne, zważywszy, iż duchowny musiał zyskać akceptację na ogół trzódki analfabetów nawykłych do rutynowych zachowań dyktowanych liturgią niedzielnej mszy ${ }^{148}$. Większe oczekiwania względem duchownych oraz kolektywna zachęta do poszerzania wiedzy teologicznej mogły mieć miejsce w środowiskach kolegiackich i bogatszych miejskich parafii. Do wspólnego cotygodniowego dyskutowania własnych niedoskonałości moralnych i szukania w ten sposób dróg wychodzenia z nich zachęcał kieleckich wikariuszy Jerzy Radziwiłł. Bractwo kapłańskie, o którym wspomniano wówczas w Bodzentynie, należało dopiero wskrzesić. Jego rola sprowadzała się jednak przede wszystkim do materialnego wspomożenia żyjących księży oraz modlitwy za zmarłych ${ }^{149}$.

${ }^{145}$ Por. L. Zygner, Synody diecezjalne metropolii gnieźnieńskiej na przełomie XIV i XV wieku (Gniezno - Kraków - Płock - Poznań - Włocławek), w: Kultura prawna w Europie Środkowej, red. A. Barciak, Katowice 2006, s. 177-192.

${ }^{146}$ Czas zakładania tych ksiąg pozostaje na ogół nieznany; zob. szerzej Kowalski, Trydenckie wyzwania. Entuzjastyczna opinia wizytatora wyrażona w Dębnie odnośnie do prowadzenia dokumentacji chrztów „nonnulis nominibus supressis” dowodzi nie tyle stanu faktycznego, gdyż tego wizytator nie był w stanie ocenić, a raczej ogólnie pozytywnego wrażenia odniesionego w tej wsi. Wizytator przyjechał tam ze Wzdołu, gdzie - jak to często jeszcze bywało - co prawda imiona ochrzczonych i zaślubionych spisywano, ale niezgodnie z zaleceniami synodalnymi; AKMKr, AV Cap 30, k. 49r., 51r.

${ }^{147} \mathrm{Na}$ podstawie Statuta nec non liber promotionum philosophorum ordinis in universitate studiorum Jagellonica ab anno 1402 ad annum 1849, red. J. Muczkowski, Cracoviæ 1849; Album studiosorum Universitatis Cracoviensis, t. 3, fasciculi 1-2, red. A. Chmiel, Cracoviæ, 1896-1904.

${ }^{148}$ Do takiej opinii upoważniają uwagi A. Wyrobisza (Małe miasta i ich mieszkańcy w późnośredniowiecznej i wczesnonowożytnej Polsce, „Przegląd Historyczny”, 95 (2004) s. 104-105). Nie wiadomo wszakże, jak dalece owa „,bierność mas”, jak ujął to Kracik (Raków katolicki, „Odrodzenie i Reformacja w Polsce", 30 (1985) s. 109), być może eksponowana jest w źródłach ponad rzeczywistość, która pozostaje poza wnikliwszą rekonstrukcją.

${ }^{149}$ AV Cap 9, s. 497, 512. Zob. B. Kumor, Statuty Bractwa Kapłańskiego Oficjałatu Pilzneńskiego przy kościele św. Jana Chrzciciela w Pilznie, „Archiwa, Biblioteki i Muzea Kościelne”, 5 
Jednoznaczna ocena uogólniająca postawy duchownych bezpośrednio zaangażowanych w cura animarum, a więc wikarych i, zdaje się, większości plebanów, jest niemożliwa. Niewątpliwie jednak wspólną cechą tego środowiska jest duma z przynależności do stanu kapłańskiego. Jest ona czytelna m.in. poprzez przewijającą się $\mathrm{w}$ źródłach emocjonalną więź $\mathrm{z}$ brewiarzem. Zapewne sięgano też po ambitniejsze pozycje, lecz nie wiadomo, jak często i z jakim skutkiem. Należy docenić nawet połowiczny sukces na tym polu, zważywszy, że zapewnienia kardynała, iż nie ma większego skarbu jak wiedza ${ }^{150}, \mathrm{z}$ trudem torowały sobie drogę pod strzechy.

Życie religijne, relacje duchownych i świeckich w prepozyturze kieleckiej drugiej połowy XVI wieku to nadal świat prowincji późnego średniowiecza, który znany jest w zarysie głównie ze źródeł postulatywnych i sądowych ${ }^{151}$. Dopełniające ten obraz fakty zaczerpnięte $\mathrm{z}$ akt oficjała oraz protokołów powizytacyjnych sugerują, że trwałą cechą miejskiego, a tym bardziej wiejskiego, życia na badanym terenie była obojętność części wiernych. Przełamywanie jej musiało być nie lada problemem ${ }^{152}$. Odosobnione zapisy poświadczające duszpasterskie zaangażowanie nie wykluczają konformizmu jako wyniku zniechęcenia. Ponadto minimalistycznie formułowane oczekiwania względem wiernych niekoniecznie skłaniały ich pasterzy do zwiększonej aktywności. Zapewne w sytuacjach szczególnych mobilizowali się oni do działania, bodźcem zaś ku temu mogły być np. obchody roku jubileuszowego ${ }^{153}$. Peryferyjne biskupie i klasztorne miasta prepozytury kieleckiej dzieliła cywilizacyjna przepaść od prężnych gospodarczo miast królewskich, jak Radom czy Sandomierz, w których działali mendykanci i do których zjeżdżała szlachta ${ }^{154}$. Nawet skąpa podstawa źródłowa uprawnia do takiego wniosku. Można więc ostrożnie założyć, że np. w XVI-wiecznych Kielcach, Bodzentynie, Wąchocku czy Kunowie próżno by szukać wysiłków świeckich na rzecz indywidualnego kształtowania świadomości religijnej, ,rzeczywistego zaangażowania laików w odnowę Kościoła”, co Mirosława Hanusiewicz-Lavallee słusznie wskazuje jako istotną cechę potrydenckich zmian ${ }^{155}$. Na kulturowej prowincji,

(1962) s. 385-392. Kongregacje dekanalne duchowieństwa wprowadzano w diecezji krakowskiej od 1602 r.; J. Kracik, Najstarsze akta kongregacji dekanalnych w Archiwum Kurii Metropolitalnej w Krakowie, „Archiwa, Biblioteki i Muzea Kościelne”, 29 (1974) s. 264.

${ }^{150}$ AKMKr, AV Cap 9, s. 498.

${ }^{151}$ Przede wszystkim Bylina, Chrystianizacja, passim. Zob. także T. Wiślicz, ,,Jak gdyby wśród pogan lub heretyków”. Polityka potrydenckiego Kościoła wobec religii ludowej i jej osobliwości w Rzeczypospolitej, w: Staropolski oglad świata. Rzeczypospolita między okcydentalizmem a orientalizacją. Przestrzeń wyobrażeń, red. R. Kołodziej, F. Wolański, Toruń 2009, t. 2, s. 38-40.

${ }^{152}$ Por. Wiślicz, Shepherds of the Catholic Flock, s. 33 i passim.

${ }^{153} \mathrm{O}$ uroczystościach takich trwających w kieleckiej kolegiacie od 8 do 24 września 1617 r. poinformowano wpisem w księdze chrztów; ADK, Km, sygn. 100, s. 2.

${ }^{154}$ Por. M. Bogucka, H. Samsonowicz, Dzieje miast i mieszczaństwa w Polsce przedrozbiorowej, Wrocław 1986, s. 117, 374; M.T. Zahajkiewicz, Miejsce zakonów w duszpasterstwie średniowiecznych miast, w: Klasztor w mieście średniowiecznym i nowożytnym, red. M. Derwich, A. Pobóg -Lenartowicz, Wrocław-Opole 2000, s. 309-314; J. Kłoczowski, Problem mendykantów i kaznodziejstwa w Polsce średniowiecznej, w: Ludzie - Kościót - Wierzenia, s. 145-149.

${ }^{155}$ Hanusiewicz-Lavallee, Dawne i nowe, s. 127-128. 
jaką była prepozytura kielecka, odnowa siłą rzeczy musiała być sprowadzona do powtórzenia apelu o poprawę dyscypliny kościelnej duchownych i świeckich. Emocjonalne więzi z sacrum budowano zapewne w typowy sposób, to jest poprzez rozwój kultu eucharystycznego i maryjnego. Dbałość o wieczne zbawienie kultywowano przede wszystkim w kręgu własnej parafialnej społeczności. Nie zaskakuje więc, że w XVII-wiecznych Daleszycach, przynależność do arcybractwa różańcowego przedstawiano jako jedyny ratunek przed grozą czyścowych mąk ${ }^{156}$. Jest to, według wszelkiego prawdopodobieństwa, ilustracja szerszej praktyki angażowania wiernych w życie lokalnej fary.

Czy większa liczba duchownych $w$ parafiach przełożyłaby się na poprawę skuteczności cura animarum? Jeśli zważyć na monity Jerzego Radziwiłła, który zachęcał księży do aktywnego duszpasterstwa poza murami kościoła, to wolno sądzić, że takie były nadzieje. Z pewnością nie wszędzie przeszkodą była szczupłość beneficjalnych dochodów. Nie wszędzie też parafialni księża liczyć mogli, jak to bywało np. w Wąchocku, na wsparcie kolatora, biskupa czy opata.

Nakreślony tu obraz każe też zastanowić się, na ile w szerszej skali problemy XVI-wiecznego polskiego Kościoła wynikały z postępów reformacji, w jakim stopniu były zaś dziedzictwem poprzednich wieków. W przeciwieństwie do sąsiednich terenów, archidiakonatów: radomskiego, sandomierskiego i lubelskiego, w prepozyturze kieleckiej udział „herezji” oraz antyklerykalnej radykalizacji ciągle katolickiej szlachty w niedostatkach życia religijnego był, zdaje się, znikomy ${ }^{157}$. Idee ewangelickie czy antytrynitarskie nie miały szans tam zaistnieć - nie tylko ze względu na ograniczenia wynikające z własności dominialnej. Powtarzane na ewangelickich synodach smutne refleksje po nieudanych próbach mobilizacji chłopów ${ }^{158}$ podzielała zapewne też spora część katolickich duchownych. Powszechna identyfikacja wiernych oraz ich pasterzy z Dobrą Nowiną, emocjonalna choć niekoniecznie budowana na strachu przed wiecznym potępieniem, była raczej dość odległą perspektywą duszpasterskiej codzienności. Brak argumentów przemawiających za szerszym zrozumieniem dla takich ambitnych celów, co nie zaskakuje, jako że synodalne wymagania przykrawano do ówczesnych, dość skromnych możliwości. Był to problem strukturalny. Jerzy Radziwiłł, wybitny

${ }^{156}$ ADK, Akta parafialne. Daleszyce, sygn. II/PD-1/2, k. 46r.

157 Jeśli interpretować zaleganie z dziesięcinami jako świadectwo takich antyklerykalnych czy antykatolickich postaw, to znów - tak jak zamiana świątyń na zbory - udokumentowane są nieliczne tylko takie przypadki. W 1577 r. Jan i Stanisław Gromadzcy, Mnichowski, Wielucki, Jędrzejowski i Szczucki odnotowani zostali w Szewnej, Stanisław Brzeźnicki w Pawłowie, Mielecki z Zeleniowa w Starej Słupi, Urszula Trześćnicka w Brzezinach, a ponadto w Daleszycach Hynkowie z Kuchar, Jan Krzysztof Kołaczkowski z Kołaczewic, Stanisław Gnoiński z Pęczelic oraz Wolscy z Żernik. W gronie tym znalazł się jednak także opat wąchocki, co każe pamiętać o innej, np. wyłącznie materialnej motywacji; AKKKr, Akp, sygn. Reg. C7, k. 127r.-128v. Nazwiska te, z jednym wyjątkiem, nie występują pośród uczestników synodów ewangelickich. Nieznany z imienia Wolski odnotowany został w protokole zjazdu odbytego w Ożarowie w 1600 r.; Akta synodów różnowierczych w Polsce, t. 3, (1571-1632), oprac. M. Sipayłł, Warszawa 1983, s. 217.

${ }^{158} \mathrm{O}$ tym ostatnio W. Kowalski, Peasants and 'Sectarians'. On the Ineffectiveness of Evangelical Persuasion in Sixteenth-Century Poland, w: Bridging the Historiographical Divides, red. É. Boillet, I. Johnson, Turnhout 2021, w druku. Tam też starsza literatura. 
pasterz swych czasów, nie miał raczej wątpliwości, że do oczekiwanych trwałych przemian wiedzie długa i wyboista droga. Ich konsekwentna implementacja rozpoczęła się krótko po śmierci kardynała, pierwsze zaś pozytywne tego efekty udokumentowano już za pasterzowania Marcina Szyszkowskiego (1616-1630).

\section{TABELE I ZESTAWIENIA}

Objaśnienia: Bardo, Dąbrowa oraz Grzegorzowice, wymieniane pośród parafii prepozytury w czasach Długosza oraz w 1529 r., z końcem stulecia nie występują już jako samodzielne placówki duszpasterskie. W XV stuleciu Baćkowice (Baczkowice) to parafia sui iuris. W 1529 r. pojawiają się jako filia parafii Łagów, w 1597 r. zaś odnotowano kościół parafialny inkorporowany do Łagowa. W 1597 r. poinformowano, że parafię w Jastrzębiu inkorporowano mansjonarzom iłżeckim, Chybice zaś włączono przed tym rokiem do Sulisławic. Parafia Brzeziny została pominięta w $L R$. Od 1491 r. świątynia w Starej Słupi była kościołem filialnym parafii Nowa Słupia. W 1597 r. kościół parafialny w Zbelutce odnotowano jako inkorporowany do Łagowa. W 1577 r. kolektorzy kontrybucji parafialnej jako „sprofanowane” odnotowali prebendę zamkową w Kurozwekach oraz kościoły w Bardzie i Grzegorzewicach. Z nieznanych powodów kontrybucji nie uiszczono w Mychowie, Szumsku i Waśniowie; AKMKr, AV Cap 8, s. 20-21, 27, 44; AKKKr, Akp, sygn. Reg. C7, k. 126r.-129v.; Księga dochodów beneficjów diecezji krakowskiej z roku 1529 (tzw. Liber retaxationum), wyd. Z. Leszczyńska -Skrętowa, Wrocław 1968; M. Derwich, Materiaty do stownika historyczno-geograficznego dóbr i dochodów dziesięcinnych benedyktyńskiego opactwa św. Krzyża na Eysej Górze do 1819 r., Wrocław 2000, s. 137; Schematyzm diecezji krakowskiej z tzw. kopiarza wiślickiego, wyd. W. Kowalski, „Archiwa, Biblioteki i Muzea Kościelne”, 81 (2004) s. 115; M. Grabkowski, Kształtowanie się sieci parafialnej w prepozyturze kieleckiej w czasach średniowiecza, „Res Gestæ”, 12(2012) s. 77-109; B.S. Kumor, Dzieje diecezji krakowskiej do roku 1795, red. J. Urban, t. 4, Kraków 2002, s. 314, 320, 324.

b.d. - brak danych m. - parafia $\mathrm{z}$ centrum $\mathrm{w}$ mieście

USTC - the Universal Short Title Catalogue, https://www.ustc.ac.uk/ [ ] - wartości przybliżone 
Tabela 1. Wysokość dochodów beneficjów parafialnych prepozytury kieleckiej według taksacji 1529 r. oraz liczba osad w parafiach ok. 1470 r.

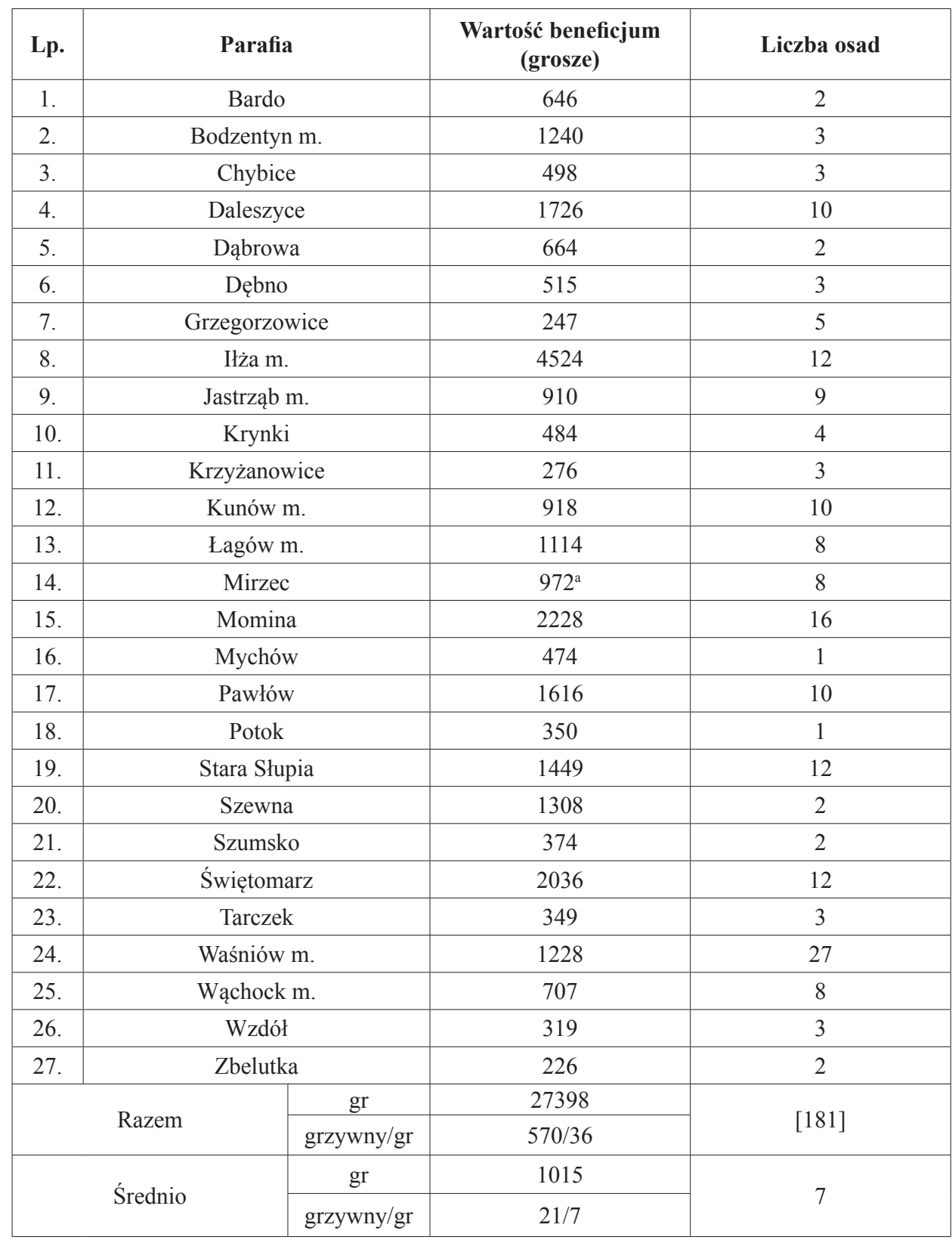

Uwaga: Przy parafiach Chybice, Grzegorzowice, Jastrząb, Momina, Stara Słupia, Szumsko, Waśniów, Wąchock podano przybliżone liczby osad.

Opracowanie na podstawie: LR, passim; Grabkowski, Ksztaltowanie się sieci parafialnej, s. 77-109.

${ }^{a}$ Bez dziesięciny konopnej i kolędy. 
Tabela 2. Uposażenie kleru pomocniczego w parafiach prepozytury kieleckiej

w latach 1529 i 1597

\begin{tabular}{|c|c|c|c|c|c|}
\hline \multirow{2}{*}{ Lp. } & \multirow{2}{*}{ Parafia } & \multicolumn{2}{|c|}{1529} & \multicolumn{2}{|c|}{1597} \\
\hline & & Liczba księży & Grosze & Liczba księży & Grosze \\
\hline 1 & 2 & 3 & 4 & 5 & 6 \\
\hline 1. & Bardo & 1 & 150 & $\mathrm{X}$ & $\mathrm{X}$ \\
\hline 2. & Baćkowice & 1 & 60 & 1 & 288 \\
\hline 3. & Bodzentyn m. & 2 & $96^{\mathrm{b}}$ & 2 & $12+20^{c}$ \\
\hline 4. & Brzeziny & . & . & 1 & 384 \\
\hline 5. & Chybice & 1 & 60 & 1 &.$^{\mathrm{d}}$ \\
\hline 6. & Daleszyce & 1 & {$\left[192^{\mathrm{e}}\right]$} & 2 & $1320+1320^{\mathrm{f}}$ \\
\hline 7. & Dąbrowa & - & - & $\mathrm{X}$ & $\mathrm{X}$ \\
\hline 8. & Dębno & - & - & - & - \\
\hline 9. & Grzegorzowice & - & - & $\mathrm{X}$ & $\mathrm{X}$ \\
\hline 10. & Jastrząb m. & 1 & 192 & 2 & $240+240^{g}$ \\
\hline 11. & Krynki & 1 & 96 & - & - \\
\hline 12. & Krzyżanowice & - & - & - & - \\
\hline 13. & Kunów m. & 1 & 96 & $1^{\mathrm{h}}$ & 720 \\
\hline 14. & Łagów m. & - & - & 1 & 384 \\
\hline 15. & Mirzec & 1 & 96 & 1 & $60^{\mathrm{i}}$ \\
\hline 16. & Momina & {$\left[2^{\mathrm{j}}\right]$} & 312 & - & - \\
\hline 17. & Mychów & 1 & 144 & - & - \\
\hline 18. & Pawłów & 1 & 120 & - & - \\
\hline 19. & Potok & - & - & - & - \\
\hline 20. & Nowa Słupia m. & 1 & 60 & 1 & 576 \\
\hline 21. & Stara Słupia & 1 & 192 & 1 & 384 \\
\hline
\end{tabular}

${ }^{\mathrm{b}}$ Ponadto dostają pół kolędy.

c Otrzymują też wyżywienie. Ponadto trzej altarzyści oraz maturista z obowiązkiem odprawiania rannej mszy; wszyscy na niewielkich czynszach.

${ }^{\mathrm{d}}$ Wikary z Sulisławic otrzymuje prawie cały dochód z tego beneficjum.

e Źródło informuje, że pleban opłaca wikarego i sługę 6 grzywien łącznie. Wikary zwyczajowo otrzymywał salarium większe niż sługa, dlatego przyjęto, iż wynosiło ono 4 grzywny.

${ }^{\mathrm{f}}$ Ponadto wikt.

g Ponadto wraz z rektorem szkoły mają udział w kweście.

${ }^{\text {h }}$ Ponadto jeszcze jeden, który pełnił też obowiązki prepozyta szpitalnego.

${ }^{i}$ Ponadto dzieli stół z plebanem. Ma też, według dawnego zwyczaju, z pewnych pól chłopskich pół snopu żyta, lub też po parę groszy iuxta certam et antiquam taxam.

j Liczba wikariuszów nieznana. Podaną w tabeli przyjąć można przez analogię np. do nieodległych, leżących po drugiej stronie Opatowa Bidzin, gdzie dwóch wikarych otrzymywało 7 grzywien, czyli 336 gr. 


\begin{tabular}{|c|c|c|c|c|c|}
\hline 1 & 2 & 3 & 4 & 5 & 6 \\
\hline 22. & Szewna & 1 & 120 & - & - \\
\hline 23. & Szumsko & - & - & - & - \\
\hline 24. & Świętomarz & {$[2]$} & 336 & [1] & 444 \\
\hline 25. & Tarczek & 1 & $48^{\mathrm{k}}$ & 1 & $480^{1}$ \\
\hline 26. & Waśniów m. & - & $-\mathrm{m}$ & 1 & 192 \\
\hline 27. & Wąchock m. & 2 & {$\left[240^{\mathrm{n}}\right]$} & $2^{\circ}$ & $480+480^{p}$ \\
\hline 28. & Wzdół & - & - & 1 & 480 \\
\hline 29. & Zbelutka & - & - & - & - \\
\hline & Razem & {$[22]$} & $\begin{array}{c}{[2610 \mathrm{gr}=} \\
54 \mathrm{grz} / 18 \mathrm{gr}]\end{array}$ & 20 & $\begin{array}{c}8504 \mathrm{gr}= \\
177 \mathrm{grz} / 8 \mathrm{gr}\end{array}$ \\
\hline & Inio w parafii & {$[1,22]$} & $\begin{array}{c}{[145 \mathrm{gr}=} \\
3 \mathrm{grz} / 1 \mathrm{gr}]\end{array}$ & 1,25 & $\begin{array}{c}532 \mathrm{gr}= \\
11 \mathrm{grz} / 3 \mathrm{gr}\end{array}$ \\
\hline \multicolumn{2}{|c|}{$\%$ parafii z wikariuszami } & \multicolumn{2}{|c|}{79} & \multicolumn{2}{|c|}{62} \\
\hline
\end{tabular}

Uwaga: W 1529 r. dochód mansjonarzy w Iłży tamtejszy wiceprepozyt oszacował na 43,5 grzywny. Dochody te dzielili równo miedzy siebie. W 1597 r. pięciu mansjonarzy iłżeckich, w tym jeden będący prepozytem szpitala, otrzymywało dziesięcinę z połowy wsi Wola, $40 \mathrm{fl}$. z parafii Jastrząb, $41 \mathrm{fl}$. z czynszów wykupnych. Ponadto jako wspólnota partycypowali w dochodach probostwa w Jastrzębiu. Mansjonarz pełniący funkcję wiceprepozyta iłżeckiego otrzymywał dodatkowo 20 fl. rocznie. Przy obliczaniu przeciętnych wydatków związanych z utrzymaniem kleru pomocniczego oraz ich średniej liczby uwzględniono jedynie te parafie, w których odnotowano wikariuszy. Podane liczby groszy informują o sumach wydawanych przez rządców parafii na utrzymanie kleru pomocniczego. Opracowanie na podstawie: AKMKr, AV Cap 8, passim; AV Cap 9, s. 512; $L R$, passim.

${ }^{\mathrm{k}}$ Ponadto dostaje cotygodniowe ofiary wiernych.

${ }^{1} \mathrm{~W}$ tym dziesięcina o wartości 2 grzywny. Ponadto dostaje 2 korce pszenicy rocznie.

m Ponadto dochody z kolędy.

${ }^{\mathrm{n}}$ Dwu wikarych i sługa otrzymują do podziału 6 grzywien.

o Są domy dla trzech.

${ }^{\mathrm{p}}$ Ponadto z klasztoru otrzymują prebendę: chleb i piwo, we środy, piątki i soboty - ryby oraz na zapusty corocznie po $8 \mathrm{fl}$. Od mieszczan dostają kolędę, a ponadto missalia: 18 korcy pszenicy i tyleż owsa. Kwestą dzielą się z rektorem szkoły. 
Tabela 3. Wysokość dochodów duchowieństwa kieleckiej kolegiaty według szacunków 1529 r.

\begin{tabular}{|c|c|c|c|}
\hline Lp. & Tytuł dochodu & $\begin{array}{c}\text { Wysokość dochodu } \\
\text { grzywny/gr }\end{array}$ & Razem \\
\hline 1. & Prepozyt & $117 / 8$ & \multirow{10}{*}{$452 / 5$} \\
\hline 2. & Dziekan & $90 / 33$ & \\
\hline 3. & Scholastyk & 31 & \\
\hline 4. & Kustosz & $62 / 36$ & \\
\hline 5. & Kanonik fundi Szewna & 55,5 & \\
\hline 6. & Kanonik fundi Sieradowice & $8 / 22$ & \\
\hline 7. & Kanonik fundi Szydłówek & $34,5 / 2$ & \\
\hline 8. & Kanonik fundi Żydów & 30 & \\
\hline 9. & Kanonik fundi Brzechów & 22 & \\
\hline \multicolumn{2}{|c|}{ Średnio } & $50 / 11$ & \\
\hline 10. & Wiceprepozyt & $17,5 / 13$ & \multirow{10}{*}{$72 / 47$} \\
\hline 11. & Wicedziekan & $11 / 8$ & \\
\hline 12. & Wicekustosz & $9 / 17$ & \\
\hline 13. & Wicescholastyk & $3 / 12$ & \\
\hline 14. & Wikariusz fundi Szewna & $6,5 / 5$ & \\
\hline 15. & Wikariusz fundi Szydłówek & $5 / 20$ & \\
\hline 16. & Wikariusz fundi Żydów & 5 & \\
\hline 17. & Wikariusz fundi Brzechów & $9 / 42$ & \\
\hline 18. & Wikaria kowalska & 4,5 & \\
\hline \multicolumn{2}{|c|}{ Średnio } & $8 / 5$ & \\
\hline \multicolumn{2}{|c|}{ Ogółem } & \multicolumn{2}{|c|}{$525 / 4$} \\
\hline
\end{tabular}

Uwaga: Niektóre sumy zostały błędnie zestawione przez autora źródła i takie przytacza Kumor, który zignorował uwzględnione tu korekty wydawczyni LR (Dzieje diecezji krakowskiej do roku 1795, red. J. Urban, t. 3, Kraków 2000, s. 143). LR pomija dochody kanonii pierzchnickiej, które według nowej taksacji $1561 \mathrm{r}$. szacowane są na 30 grzywien i 18 gr. Ponadto prebenda św. Anny z dochodem 27/5 grzywny (w 1577 r. 12/24 grzywny).

Opracowanie na podstawie: LR, passim; AKKKr, sygn. Reg. C6, k. 92r.-93r.; Reg. C7, k. 125r., 126r.

Tabela 4. Liczba duchownych w parafiach prepozytury kieleckiej w latach 1529 , 1577 i 1597

\begin{tabular}{|c|c|c|c|c|}
\hline Lp. & Parafia & $\mathbf{1 5 2 9}$ & $\mathbf{1 5 7 7}$ & $\mathbf{1 5 9 7}$ \\
\hline $\mathbf{1}$ & $\mathbf{2}$ & $\mathbf{3}$ & $\mathbf{4}$ & $\mathbf{5}$ \\
\hline 1. & Bardo & 2 & $\mathrm{X}$ & - \\
\hline 2. & Baćkowice & 1 & - & 1 \\
\hline
\end{tabular}




\begin{tabular}{|c|c|c|c|c|}
\hline 1 & 2 & 3 & 4 & 5 \\
\hline 3. & Bodzentyn m. & 4 & {$\left[5^{q}\right]$} & 4 \\
\hline 4. & Brzeziny & . & 3 & 2 \\
\hline 5. & Chybice & 2 & 1 & 2 \\
\hline 6. & Daleszyce & 2 & 2 & 3 \\
\hline 7. & Dąbrowa & 1 & 1 & - \\
\hline 8. & Dębno & 1 & 1 & 1 \\
\hline 9. & Grzegorzowice & 1 & $X$ & - \\
\hline 10. & Iłża & [7] & 2 & 6 \\
\hline 11. & Jastrząb m. & 2 & $-\mathrm{r}$ & - \\
\hline 12. & Krynki & 2 & 2 & 1 \\
\hline 13. & Krzyżanowice & 1 & 1 & 1 \\
\hline 14. & Kunów m. & 2 & 3 & 3 \\
\hline 15. & Łagów m. & 1 & 1 & 2 \\
\hline 16. & Mirzec & 2 & 1 & 2 \\
\hline 17. & Momina & [3] & 2 & 1 \\
\hline 18. & Mychów & 2 & . & 1 \\
\hline 19. & Pawłów & 2 & 3 & 1 \\
\hline 20. & Potok & 1 & 1 & 1 \\
\hline 21. & Nowa Słupia m. & 1 & - & 2 \\
\hline 22. & Stara Słupia & 1 & 3 & - \\
\hline 23. & Szewna & 2 & 1 & 1 \\
\hline 24. & Szumsko & 1 & . & 1 \\
\hline 25. & Świętomarz & [3] & 2 & . \\
\hline 26. & Tarczek & 2 & 2 & 2 \\
\hline 27. & Waśniów m. & 1 & . & 1 \\
\hline 28. & Wąchock m. & 2 & 1 & 2 \\
\hline 29. & Wzdół & 1 & 2 & 2 \\
\hline 30. & Zbelutka & 1 & 1 & - \\
\hline \multicolumn{2}{|c|}{ Razem } & [54] & [41] & [42] \\
\hline \multicolumn{2}{|c|}{ Indeks } & 100 & 76 & 78 \\
\hline \multicolumn{2}{|c|}{ Średnio w parafii } & {$[1,80]$} & {$[1,58]$} & {$[1,75]$} \\
\hline
\end{tabular}

q Brak pewności, że altarysta św. Jana Chrzciciela oraz św. Anny Andrzej Gryzilikus nie jest tożsamy z jednym z dwu anonimowych wikarych. Wikariuszem parafialnym mógł być też proboszcz szpitalnej kaplicy Jan Cyganek; AKKKr, Akp, sygn. Reg. C7, k. 128v.-129r.

${ }^{\mathrm{r}}$ Beneficjum to trzymał, razem z iłżeckim, Jan Strzemaski; AKKKr, Akp, sygn. Reg. C7, k. $129 \mathrm{v}$. 
Uwaga: oprócz proboszczów i wikariuszów w tabeli uwzględniono duchownych obsługujących szpitale i altarie. W 1577 r. poborcy odnotowali 28 parafii (oraz parafię kolegiacką i kaplicę w Kurozwękach). Na 25 czynnych kościołów, nie licząc kolegiaty, wikariuszy zastano w 13, z czego w 5 parafiach więcej niż jednego.

Opracowanie na podstawie: LR, passim; AKKKr, Akp Reg. C7, k. 126r.-127v.; AKMKr, AV Cap 8, passim.

Tabela 5. Czas uzyskania święceń przez plebanów i wikariuszy prepozytury kieleckiej odnotowanych w 1597 r.

\begin{tabular}{|c|c|c|c|c|c|c|}
\hline \multirow{2}{*}{ Lata } & \multicolumn{2}{|c|}{ Plebani } & \multicolumn{2}{c|}{ Wikariusze } & \multirow{2}{*}{ Ogólem } & \multirow{2}{*}{$\%$} \\
\cline { 2 - 5 } & Liczba & $\mathbf{\%}$ & Liczba & $\mathbf{\%}$ & & \\
\hline $1575-1580$ & 6 & 25,00 & 3 & 12,50 & 9 & 18,75 \\
\hline $1581-1585$ & 2 & 8,33 & 1 & 4,17 & 3 & 6,25 \\
\hline $1586-1590$ & 4 & 16,67 & 4 & 16,67 & 8 & 16,67 \\
\hline $1591-1597$ & 7 & 29,17 & 8 & 33,33 & 15 & 31,25 \\
\hline Razem & 19 & $\mathrm{X}$ & 16 & $\mathrm{X}$ & 35 & $\mathrm{X}$ \\
\hline Brak danych & 5 & 20,83 & 8 & 33,33 & 13 & 27,08 \\
\hline Ogółem & 24 & 100,00 & 24 & 100,00 & 48 & 100,00 \\
\hline
\end{tabular}

Uwaga: wikariuszy - prepozytów szpitalnych w Bodzentynie, Iłży i w Kunowie zaliczono jako plebanów.

Opracowanie na podstawie: AKMKr, AV Cap 8, passim; Księgi egzaminów, passim.

Tabela 6. Duchowni prepozytury kieleckiej w 1597 r. według najwyższych znanych święceń

\begin{tabular}{|c|c|c|c|c|}
\hline Święcenia & Plebani & Wikariusze & Ogółem & \% \\
\hline Prezbiterat & 18 & 16 & 34 & 70,83 \\
\hline Diakonat & 1 & 3 & 4 & 8,33 \\
\hline Subdiakonat & - & 1 & 1 & 2,08 \\
\hline Nieznane & 5 & 4 & 9 & 18,76 \\
\hline Razem & 24 & 24 & 48 & 100,00 \\
\hline
\end{tabular}

Opracowanie na podstawie: AKMKr, AV Cap 8, passim; Księgi egzaminów, passim. 
Tabela 7. Pochodzenie terytorialne duchowieństwa prepozytury kieleckiej według rejestracji 1529 i 1597 r.

\begin{tabular}{|c|c|c|c|c|}
\hline Miejsce pochodzenia & Plebani & Wikariusze & Ogólem & $\%$ \\
\hline \multicolumn{5}{|c|}{1529} \\
\hline Prepozytura kielecka & 3 & . & . & . \\
\hline $\begin{array}{c}\text { Pozostałe tereny diecezji } \\
\text { krakowskiej }\end{array}$ & 8 & . & . & . \\
\hline Spoza diecezji krakowskiej & 3 & . & . & . \\
\hline Nieznane & 13 & . & . & . \\
\hline Razem & 27 & . & . & . \\
\hline \multicolumn{5}{|c|}{1597} \\
\hline Prepozytura kielecka & 7 & 11 & 18 & 37,50 \\
\hline $\begin{array}{l}\text { Pozostałe tereny diecezji } \\
\text { krakowskiej }\end{array}$ & 8 & 8 & 16 & 33,33 \\
\hline Spoza diecezji krakowskiej & 3 & 2 & 5 & 10,42 \\
\hline Nieznane & 6 & 3 & 9 & 18,75 \\
\hline Razem & 24 & 24 & 48 & 100,00 \\
\hline$\%$ & 50 & 50 & 100 & $\mathrm{X}$ \\
\hline
\end{tabular}

Opracowanie na podstawie: AKMKr, AV Cap 8, passim; LR, passim; Księgi egzaminów, passim.

\section{Zestawienie 1. Książki w bibliotekach parafialnych prepozytury kieleckiej według rejestracji 1597 i 1610 r.}

\begin{tabular}{|c|c|c|}
\hline Księgi liturgiczne & 1597 & 1610 \\
\hline \multicolumn{3}{|c|}{ Baczkowice } \\
\hline Mszał krakowski & b.d. & 1 \\
\hline Mszał rzymski & 1 & 1 \\
\hline Agenda & 1 & diecezji włocławskiej $^{s}$ \\
\hline Graduał & 1 & stary, pergaminowy \\
\hline Antyfonarz & 1 & stary, pergaminowy \\
\hline Psałterz & b.d. & stary, pergaminowy \\
\hline
\end{tabular}

s Zapewne Agendorum Ecclesiasticorum Liber in usum Provincice Gnesnensis conscriptus, t. 1-3, Coloniæ 1579 lub agenda Marcina Kromera z 1574 r.; W. Nowak, Geneza agendy biskupa Marcina Kromera, „Studia Warmińskie”, 6 (1969) s. 173-210; tenże, Biskup Marcin Kromer jako liturgista, „Komunikaty Mazursko-Warmińskie”, (2012) nr 3, s. 573-575. 


\begin{tabular}{|c|c|c|}
\hline \multicolumn{3}{|c|}{ Bodzentyn, parafia $^{t}$} \\
\hline Mszał rzymski & 1 & 4 \\
\hline Agenda nowa & Powodowskiego $^{u}$ & 1 \\
\hline Graduał & b.d. & 2 - nowy i dawny \\
\hline Antyfonarz & b.d. & 1 \\
\hline Psałterz & b.d. & 1 nowy i 2 pergaminowe stare \\
\hline \multicolumn{3}{|c|}{ Bodzentyn, prepozytura szpitalna } \\
\hline Mszał rzymski & $1^{\mathrm{v}}$ & b.d. \\
\hline Agenda stara & 1 & b.d. \\
\hline \multicolumn{3}{|c|}{ Brzeziny $^{\mathrm{w}}$} \\
\hline Mszał krakowski & 3 (jeden pergaminowy, dwa papierowe) & - \\
\hline Mszał rzymski & 1 & 1 \\
\hline Agenda nowa & b.d. & Agenda „recens”“ \\
\hline Graduał & b.d. & stary oraz drugi pergaminowy \\
\hline Antyfonarz & 1 & 1 \\
\hline Psałterz & 1 & 1 \\
\hline Brewiarz & 1 & b.d. \\
\hline \multicolumn{3}{|c|}{ Chybice } \\
\hline Mszał rzymski & 1 & 2 \\
\hline Agenda nowa & 1 & 1 \\
\hline Graduał & b.d. & $\begin{array}{c}\text { stary, ze współczesnymi uzu- } \\
\text { pełnieniami }\end{array}$ \\
\hline Antyfonarz & pergaminowy & rękopiśmienny \\
\hline Psałterz & b.d. & stary \\
\hline \multicolumn{3}{|c|}{ Daleszyce } \\
\hline Mszał rzymski & b.d. & 4 \\
\hline Graduał & b.d. & nowy \\
\hline Antyfonarz & b.d. & 1 \\
\hline
\end{tabular}

${ }^{\mathrm{t}}$ Ponadto w 1597 r. informacja o licznych, niewymienionych z tytułów księgach spisanych w inwentarzu. W 1610 r. dodano ,sunt plurima libri veteres, antiqua scripta exarati, ecclesiastici, quorum nullus est usus"; AKMKr, AV Cap 30, k. 59v.

"Agenda seu ritus sacramentorum nec non cceremoniarum ecclesiasticarum, Ad uniformem Ecclesiarum per universas Prouincias Regni Polonice usum, officio Romano conformati. Ex decreto Synodi Prouincialis denuo conscripti et editi, vol. 1-2, Cracoviæ 1591 (USTC 242844).

${ }^{v}$ Nie używają. Posługują się agendą.

w Ponadto w 1597 r. wspomniano ogólnie księgi pomocne kaznodziejstwu. Te jako „libri sacri” spisane w inwentarzu odnotowano także w $1610 \mathrm{r}$.

x Zob. przypis „u”. 


\begin{tabular}{|c|c|c|}
\hline Psałterz & b.d. & 2 \\
\hline \multicolumn{3}{|c|}{ Dębno $^{y}$} \\
\hline Mszał krakowski & 1 & - \\
\hline Mszał rzymski & 1 & 2 \\
\hline Agenda nowa & $1 ?$ & $1 ?$ \\
\hline Graduał & 1 & - \\
\hline \multicolumn{3}{|c|}{ Ilża, parafia ${ }^{z}$} \\
\hline Mszał rzymski & 1 & 2 \\
\hline Agenda nowa & - & $1^{\text {aa }}$ \\
\hline Graduał & 1 & $\begin{array}{c}\text { dwa papierowe i stary perga- } \\
\text { minowy }\end{array}$ \\
\hline Antyfonarz & 1 & - \\
\hline Psałterz & nieznana liczba psałterzy rzymskich & - \\
\hline \multicolumn{3}{|c|}{ Iłża, prepozytura szpitalna } \\
\hline Mszał rzymski & 1 & b.d. \\
\hline \multicolumn{3}{|c|}{ Jastrząb } \\
\hline Mszał krakowski & 2 & - \\
\hline Mszał rzymski & 1 & 2 \\
\hline Agenda stara & gnieźnieńska $^{\mathrm{ab}}$ & 1 porwana \\
\hline Graduał & - & 1 \\
\hline Antyfonarz & stary porwany & 1 \\
\hline Psałterz & - & 1 stary i porwany \\
\hline \multicolumn{3}{|c|}{ Krynki } \\
\hline Mszał krakowski & 2 & 2 \\
\hline Mszał rzymski & 1 & 1 \\
\hline Agenda nowa & - & 1 \\
\hline Graduał & 1 & pergaminowy stary \\
\hline Antyfonarz & 1 & 1 \\
\hline Psałterz & 1 & - \\
\hline Brewiarz & krakowski & 2 \\
\hline
\end{tabular}

${ }^{y}$ Ponadto w 1597 r. wymieniono postyllę Wujka. Być może była to Postylla większa, ogłoszona w Krakowie w 1573 r. (USTC 242157) lub inne późniejsze wydanie pod zmienionym tytułem; zob. K. Estreicher, Bibliografia, cz. 3, t. 22, ogólnego zbioru t. 33, Kraków 1939, s. 389-397.

${ }^{z}$ Ponadto w 1597 r. wspomniano o ok. 80 księgach z zakresu teologii, filozofii i homiletyki wyliczonych w osobnym inwentarzu.

aa Zapewne wymieniona już wyżej Hieronima Powodowskiego, Agenda seu ritus sacramento$\operatorname{rum}(1591)$.

ab Zapewne Agenda sive obsequiale secundum rubricam ecclesie metropolitane Gnesnensis, Kraków 1512 (USTC 240519) lub późniejsze wydania pod zmienionymi tytułami. 


\begin{tabular}{|c|c|c|}
\hline \multicolumn{3}{|c|}{ Krzyżanowice } \\
\hline Mszał krakowski & 2 & - \\
\hline Mszał rzymski & 1 & 1 \\
\hline Agenda stara & - & 1 \\
\hline Agenda nowa & nieznana liczba & - \\
\hline Graduał & - & nowy \\
\hline Antyfonarz & - & stary pergaminowy \\
\hline Brewiarz & - & stary $^{\mathrm{ac}}$ \\
\hline \multicolumn{3}{|c|}{ Kunów, parafia } \\
\hline Mszał krakowski & b.d. & - \\
\hline Mszał rzymski & b.d. & 2 \\
\hline Agenda stara & b.d. & 2 \\
\hline Graduał & b.d. & nowy i stary pergaminowy \\
\hline Antyfonarz & b.d. & nowy i stary pergaminowy \\
\hline Psałterz & b.d. & nowy i stary papierowy \\
\hline \multicolumn{3}{|c|}{ Lagów } \\
\hline Mszał rzymski & 1 & 4 \\
\hline Agenda nowa & Powodowskiego & 1 \\
\hline Graduał & pergaminowy & $\begin{array}{c}\text { stary pergaminowy oraz nowy } \\
\text { papierowy }\end{array}$ \\
\hline Antyfonarz & b.d. & dwa pergaminowe \\
\hline Psałterz & b.d. & stary \\
\hline \multicolumn{3}{|c|}{ Mirzec $^{\text {ad }}$} \\
\hline Mszał rzymski & b.d. & 3 \\
\hline Agenda nowa & b.d. & 1 \\
\hline Graduał & b.d. & 1 \\
\hline Antyfonarz & b.d. & 1 \\
\hline Psałterz & b.d. & 1 \\
\hline \multicolumn{3}{|c|}{ Momina } \\
\hline Mszał krakowski & 2 & b.d. \\
\hline
\end{tabular}

${ }^{\text {ac }} \mathrm{W}$ miejsce psałterza.

${ }^{a d} \mathrm{~W} 1610$ r. zapisano ponadto homilie Augustyna oraz De civitate Dei, komentarze Jana Chryzostoma do ewangelii wg Jana i Mateusza, Concordia discordantium canonum Gracjana, kazania Chryzostoma, bliżej nieokreślone cztery tomy dzieł Orygenesa. Ponadto Stanisława Hozjusza, Confessio catholica fidei Christiana, $1557^{1}$ (USTC 624505, 624569), jedno z wydań Guillaume'a Duranda, Rationale divinorum officiorum, $1459^{1}$ (USTC 744508), Józefa Flawiusza, De antiquitatibus ac De bello Iudaico, $1502^{1}$ (USTC 762336), bliżej nieznana konkordancja biblijna oraz bliżej nieznane wydanie konstytucji soboru w Konstancji. 


\begin{tabular}{|c|c|c|}
\hline Mszał rzymski & 1 & b.d. \\
\hline Agenda stara & gnieźnieńska & b.d. \\
\hline Agenda nowa & Powodowskiego ae & b.d. \\
\hline Graduał & 1 & b.d. \\
\hline Antyfonarz & 1 & b.d. \\
\hline Psałterz & 1 & b.d. \\
\hline \multicolumn{3}{|c|}{ Mychów } \\
\hline Mszał rzymski & b.d. & 1 \\
\hline Agenda nowa & b.d. & 1 \\
\hline Graduał & b.d. & 1 \\
\hline Antyfonarz & b.d. & stary papierowy \\
\hline Psałterz & b.d. & stary pergaminowy \\
\hline \multicolumn{3}{|c|}{ Nowa Słupia } \\
\hline Mszał rzymski & b.d. & 1 \\
\hline Agenda & b.d. & 1 \\
\hline Graduał & b.d. & 1 \\
\hline Antyfonarz & b.d. & 1 \\
\hline Psałterz & b.d. & nowy \\
\hline \multicolumn{3}{|c|}{ Pawlów $^{\text {af }}$} \\
\hline Mszał krakowski & 1 & - \\
\hline Mszał rzymski & 1 & 1 \\
\hline Agenda stara & 1 & 1 \\
\hline Agenda nowa & 1 & - \\
\hline Graduał & - & nowy \\
\hline Antyfonarz & 1 & rękopiśmienny \\
\hline \multicolumn{3}{|c|}{ Potok } \\
\hline Mszał krakowski & 1 & - \\
\hline Mszał rzymski & 1 & 1 \\
\hline Agenda stara & 1 & - \\
\hline Agenda nowa & 1 & 1 \\
\hline Graduał & 2 & nowy \\
\hline Antyfonarz & - & nowy \\
\hline Brewiarz & - & dwa, zamiast psałterza \\
\hline \multicolumn{3}{|c|}{ Stara Słupia } \\
\hline Mszał krakowski & 1 & - \\
\hline
\end{tabular}

ae Zob. przypis ,u”.

${ }^{\text {af }}$ Ponadto w 1597 r. nieokreślona bliżej książka o sakramentach, być może S. Karnkowskiego, Napominania dla plebanów, Kraków 1568 lub edycja z1577 r. (USTC 243454, 242259) oraz biblia. 


\begin{tabular}{|c|c|c|}
\hline Mszał rzymski & 1 & 1 \\
\hline Agenda stara & 1 & - \\
\hline Agenda nowa & 1 & 1 \\
\hline Graduał & - & nowy \\
\hline \multicolumn{3}{|c|}{ Szewna $^{\text {ag }}$} \\
\hline Mszał stary & 5 & 1 \\
\hline Mszał rzymski & - & 2 \\
\hline Agenda stara & 1 & 1 \\
\hline Graduał & 1 & nowy \\
\hline Antyfonarz & 1 & nowy \\
\hline Psałterz & 1 & nowy \\
\hline Brewiarz & minimum dwa & - \\
\hline \multicolumn{3}{|c|}{ Szumsko } \\
\hline Mszał rzymski & 1 & 1 \\
\hline Agenda nowa & 1 & 1 \\
\hline Graduał & - & stary pergaminowy \\
\hline Antyfonarz & - & stary pergaminowy \\
\hline \multicolumn{3}{|c|}{ Świętomarz ${ }^{\text {ah }}$} \\
\hline Mszał rzymski & b.d. & 1 \\
\hline Agenda & b.d. & nowa \\
\hline Graduał & b.d. & nowy \\
\hline Antyfonarz & b.d. & nowy \\
\hline Psałterz & b.d. & nowy \\
\hline \multicolumn{3}{|c|}{ Tarczek } \\
\hline Mszał krakowski & 2 & - \\
\hline Mszał rzymski & 1 & 1 \\
\hline Agenda stara & krakowska & - \\
\hline Agenda nowa & Powodowskiego ${ }^{\text {ai }}$ & 1 \\
\hline
\end{tabular}

ag Ponadto w 1597 r. zapisano biblię, Thesaurus de sanctis, zapewne Piotra de Palude OP [Sermones Thesauri novi de sanctis, Strasbourg 1484 (USTC 749988)] lub jedno z późniejszych wydań; Sermones de tempore et de sanctis, sive Hortulus regince Meffreta, $1483^{1}$ (USTC 747148). W $1610 \mathrm{r}$. wspomniano dwa zbiory kazań.

ah Ponadto w 1610 r. wymieniono Jakuba Wujka, Postilla Catholica, 1573-15751 (USTC 243477), zbiór kazań określony jako „thesaurus sermonum” w dwu tomach, dekret Gracjana oraz biblię. Wszystkie książki określono jako stare.

ai Zob. przypis ,u”.

aj Wpisany do pergaminowej biblii. Ponadto bliżej nieokreślone: kanony, postylla polska oraz tezaurus. 


\begin{tabular}{|c|c|c|}
\hline Graduał & $1^{\text {aj }}$ & stary pergaminowy \\
\hline Antyfonarz & - & stary papierowy \\
\hline \multicolumn{3}{|c|}{ Waśniów ${ }^{\mathrm{ak}}$} \\
\hline Mszał krakowski & 1 & 2 \\
\hline Mszał rzymski & 1 & 2 \\
\hline Agenda stara & 1 & - \\
\hline Agenda nowa & Powodowskiego ${ }^{\text {al }}$ & 1 \\
\hline Graduał & 1 & nowy \\
\hline Antyfonarz & 1 & nowy \\
\hline Psałterz & 1 & nowy \\
\hline \multicolumn{3}{|c|}{ Wąchock $^{\text {am }}$} \\
\hline Mszał rzymski & 1 & 2 \\
\hline Agenda stara & 1 & 1 \\
\hline Graduał & 1 & stary \\
\hline Antyfonarz & - & stary i nowy \\
\hline Psałterz & stary pergaminowy & nowy \\
\hline \multicolumn{3}{|c|}{ Wzdól $^{\text {an }}$} \\
\hline Mszał krakowski & - & 1 \\
\hline Mszał rzymski & 1 & 1 \\
\hline Agenda nowa & 1 & 1 \\
\hline Graduał & stary drukowany & nowy \\
\hline Antyfonarz & - & nowy \\
\hline Psałterz & - & nowy \\
\hline \multicolumn{3}{|c|}{ Zbelutka } \\
\hline Mszał rzymski & 1 & 1 \\
\hline Agenda nowa & 1 & włocławska ${ }^{\text {ao }}$ \\
\hline Graduał & - & stary pergaminowy \\
\hline
\end{tabular}

ak Ponadto w 1610 r. odnotowano Jakuba Wujka, Postilla Catholica, 1573-15751 (USTC 243477) oraz tzw. biblię Leopolity Biblia to jest księgi Starego y Nowego Zakonu, 1560-1561 (USTC 241727).

al Zob. przypis ,u”.

am Ponadto w 1597 r. wspomniano „libri plurimi, tam in sacris, quam in profanis autoribus”; AKMKr, AV Cap 8, s. 25. W 1610 r. odnotowano zaś biblię Leopolity (zob. wyżej), F. Joannis Hofmeister Augustiniani et ecclesiaste Colmarien[sis] in utrasque s. Pauli ad corinthios episcolas homilie, 1545 (USTC 658277).

an Ponadto w 1597 r. odnotowano katechizm rzymski oraz nieokreślone statuty prowincjalne; AKMKr, AV Cap 8, s. 3.

ao Zob. przypis ,"s”. 


\begin{tabular}{|c|c|c|}
\hline Antyfonarz & - & rękopiśmienna kopia \\
\hline Psałterz & - & papierowy \\
\hline
\end{tabular}

Uwaga: W 1597 r. w Nowej Słupi zapisano, że są księgi tylko do śpiewu.

Opracowanie na podstawie: AKMKr, AV Cap 8, passim; AV Cap 9, passim.

\section{Zestawienie 2. Bractwa religijne w prepozyturze kieleckiej w latach 1597 i 1610}

\begin{tabular}{|c|c|c|}
\hline Bractwo & 1597 & 1610 \\
\hline \multicolumn{3}{|c|}{ Baczkowice } \\
\hline Ubogich & b.d. & $\begin{array}{l}\mathrm{Z} \text { dawna założone, lecz reaktywo- } \\
\text { wane przez bpa Piotra Tylickiego } \\
\text { (czyli po } 1607 \text { r.) }\end{array}$ \\
\hline \multicolumn{3}{|c|}{ Bodzentyn } \\
\hline Literackie & b.d. & Aktywne? \\
\hline Cechowe & b.d. & Aktywne? \\
\hline \multicolumn{3}{|c|}{ Daleszyce } \\
\hline Literackie & b.d. & $\begin{array}{l}\text { Zbierają się w święta na msze wo- } \\
\text { tywne o NMP }\end{array}$ \\
\hline Cechowe & b.d. & $\begin{array}{c}\text { Zbierają się na mszach za zmarłych } \\
\text { braci }\end{array}$ \\
\hline \multicolumn{3}{|c|}{ Dębno } \\
\hline Ubogich & $\begin{array}{l}\text { Zapewne to wspomniane bez nazwy } \\
\text { jako założone w } 1472 \mathrm{r} \text {. }\end{array}$ & Odnowione w nieodległym czasie \\
\hline \multicolumn{3}{|c|}{ Ilłża } \\
\hline Św. Anny & b.d. & $\begin{array}{c}\text { Założone w nieodległej przeszłości. } \\
\text { Bez majątku, ale liczba członków } \\
\text { rośnie }\end{array}$ \\
\hline Literackie & Z przywilejem kard. J. Radziwiłła & b.d. \\
\hline Cechowe & b.d. & Czynne, dawne i nowe \\
\hline \multicolumn{3}{|c|}{ Kielce } \\
\hline Literackie & Aktywne? & b.d. \\
\hline \multicolumn{3}{|c|}{ Krynki } \\
\hline Ubogich & b.d. & $\begin{array}{c}\text { Założone przez bpa Jana Rzeszow- } \\
\text { skiego. Inkorporowano do niego } \\
\text { bractwo bartników }\end{array}$ \\
\hline \multicolumn{3}{|c|}{ Kunów } \\
\hline Św. Anny & b.d. & Aktywne \\
\hline Literackie & b.d. & Zaniedbane \\
\hline
\end{tabular}




\begin{tabular}{|c|c|c|}
\hline Cechowe & b.d. & Zaniedbane \\
\hline \multicolumn{3}{|c|}{ Lagów } \\
\hline Św. Anny & Niezatwierdzone & b.d. \\
\hline \multicolumn{3}{|c|}{ Mirzec } \\
\hline Nieokreślone & $\begin{array}{l}\text { W } 1434 \text { r. założone przez bpa Zbi- } \\
\text { gniewa Oleśnickiego }\end{array}$ & b.d. \\
\hline \multicolumn{3}{|c|}{ Nowa Słupia } \\
\hline Ubogich & b.d. & $\begin{array}{l}\text { Założone w } 1441 \text { r. Popularne wśród } \\
\text { miejskich rzemieślników, jako że } \\
\text { nie brak wśród nich pobożnych lu- } \\
\text { dzi Wielu z nich udało się wyszko- } \\
\text { lić, aby wspomagali liturgię mszalną }\end{array}$ \\
\hline \multicolumn{3}{|c|}{ Szewna } \\
\hline Ubogich & b.d. & Nowo zaprowadzone? \\
\hline $\begin{array}{l}\text { Najświętszego } \\
\text { Ciała Chrystusa }\end{array}$ & b.d. & Założone w 1546 r. Czynne \\
\hline \multicolumn{3}{|c|}{ Świętomarz } \\
\hline Ubogich & b.d. & $\begin{array}{c}\text { Kwartalnie oraz w wybranych } \\
\text { tygodniach odprawiają wigilie } \\
\text { i msze zaduszne. W niedziele po- } \\
\text { winni zbierać się na siedmiokrotne } \\
\text { odmawianie Ave, ale tego nie robią. } \\
\text { Jako że brak chętnych do dawania } \\
\text { (kwartalnie?) po } 2 \text { gr do brackiej } \\
\text { skrzynki, ofiarują po groszu. Z tego } \\
\text { opłacają księży }\end{array}$ \\
\hline \multicolumn{3}{|c|}{ Tarczek } \\
\hline Nieokreślone & b.d. & $\begin{array}{l}\text { Założone przez bpa Jana (tj. przed } \\
1538 \text { r.). Zbierają się kwartalnie na } \\
\text { msze za zmarłych. Każdy brat ofia- } \\
\text { ruje wtedy } 5 \text { Ojcze nasz, } 7 \text { Zdrowaś } \\
\text { Maria i } 7 \text { Symboli apostolskich, } \\
\text { które to modlitwy głośno recytują }\end{array}$ \\
\hline \multicolumn{3}{|c|}{ Waśniów } \\
\hline Św. Anny & b.d. & $\begin{array}{c}\text { Założone przez Jana Dymitra So- } \\
\text { likowskiego, abpa lwowskiego (tj. } \\
\text { w latach 1583-1603) }\end{array}$ \\
\hline $\begin{array}{l}\text { Najświętszego } \\
\text { Ciała Chrystusa }\end{array}$ & b.d. & Nieaktywne \\
\hline \multicolumn{3}{|c|}{ Wąchock } \\
\hline Św. Anny & Aktywne & Aktywne \\
\hline
\end{tabular}




\begin{tabular}{|c|c|c|}
\hline Literackie & b.d. & $\begin{array}{c}\text { Zaniedbane. Wikariusze zabierali } \\
\text { ofiary na modlitwy zaduszne i nie } \\
\text { dzielili się z braćmi, którzy uczest- } \\
\text { niczyli w mszach }\end{array}$ \\
\hline Cechowe & b.d. & Spotykają się, lecz nieregularnie \\
\hline
\end{tabular}

Opracowanie na podstawie: AKMKr, AV Cap 8, AV Cap 9, AV Cap 30.

\section{REFERENCES / BIBLIOGRAFIA}

\section{Źródla rękopiśmienne}

Archiwum Diecezjalne w Kielcach

Akta parafialne. Daleszyce, sygn. II/PD-1/2.

Księgi metrykalne parafii rzymskokatolickiej w Kielcach (Katedra), sygn. 100.

Archiwum Kapituły Katedralnej w Krakowie

Akta kontrybucji parafialnych (subsidium charitativum), sygn. Reg. C5, Reg. C6, Reg. C7.

Archiwum Kurii Metropolitalnej w Krakowie

Acta officialatus Kielcensis, sygn. A. Off. 1.

Acta visitationis, sygn. AV 2.

Acta visitationis capitularis, AV Cap 1, AV Cap 8, AV Cap 9, AV Cap 30, AV Cap 65.

\section{Wydawnictwa źródłowe}

Acta capitulorum nec non iudiciorum ecclesiasticorum selecta, vol. 2: Acta iudiciorum ecclesiasticorum diocesum Gneznensis et Poznaniensis (1403-1530), wyd. Bolesław Ulanowski, Kraków 1902.

Akta synodów różnowierczych w Polsce, t. 3: (1571-1632), oprac. M. Sipayłł, Warszawa 1983.

Corpus inscriptionum Poloniae, t. 7: Województwo radomskie, z. 1: Radom i Itża wraz z regionem, wyd. Waldemar Kowalski, red. Zenon Guldon, Warszawa 1992.

Joannis Dlugossii senioris canonici Cracoviensis Opera omnia, vol. 8: Liber beneficiorum dioecesis Cracoviensis, t. 2: Ecclesiae parochiales, ed. A. Przezdziecki, Cracoviae 1864.

Inwentarz klucza kieleckiego biskupstwa krakowskiego z 1645 roku, wyd. J. Muszyńska, Kielce 2003.

Księga dochodów beneficjów diecezji krakowskiej z roku 1529 (tzw. Liber retaxationum), wyd. Zofia Leszczyńska-Skrętowa, Wrocław 1968.

Księgi egzaminów do święceń w diecezji krakowskiej z lat 1573-1614, oprac. Z. Pietrzyk, Kraków 1991.

Najstarsze statuty synodalne krakowskie biskupa Nankera z 2 października 1320 r., wyd. Jan Fijałek, Kraków 1915.

Niesiecki Kasper, Herbarz polski, wyd. J. N. Bobrowicz, t. 6-9, Lipsk 1841-1842.

Polska XVI wieku pod względem geograficzno-statystycznym, [oprac.] A. Pawiński, t. 3: Małopolska, Warszawa 1886. 
Siarczyński Franciszek, Opis powiatu radomskiego, wyd. T. Lipiński, Warszawa 1847. Statuta nec non liber promotionum philosophorum ordinis in universitate studiorum Jagellonica ab anno 1402 ad annum 1849, red. J. Muczkowski, Cracoviae 1849.

Statuty synodalne wieluńsko-kaliskie Mikołaja Traby z r. 1420 z materiałów przysposobionych przez B. Ulanowskiego, wyd. Jan Fijałek, Adam Vetulani, Kraków 1915-19201951.

Subera Ignacy, Synody prowincjonalne arcybiskupów gnieźnieńskich. Wybór tekstów ze zbioru Jana Wężka z r. 1761, Warszawa 1981

\section{Opracowania}

Ariès Philippe, Człowiek i śmierć, Warszawa 1989, s. 73-81.

Biedrzycka Agnieszka, Roman Kawecki, Szyszkowski Marcin h Ostoja, w: Polski stownik biograficzny, t. 50, red. A. Romanowski, Warszawa-Kraków 2014-2015, s. 392-406.

Bogucka Maria, Henryk Samsonowicz, Dzieje miast i mieszczaństwa w Polsce przedrozbiorowej, Wrocław 1986.

Boniecki Adam, Herbarz polski, cz. 1, t. 1-13, Warszawa 1899-1909.

Bracha Krzysztof, Commentaries on the Decalogue in the Late Middle Ages: Between Method and Catechesis. Poland in the European Context, w: Glossae - Scholia Commentarii. Studies on Commenting Texts in Antiquity and Middle Ages, red. M. Mejor, K. Jażdżewska, A. Zajchowska, Frankfurt am Main 2014, s. 183-190.

Bracha Krzysztof, Nauczanie kaznodziejskie w Polsce późnego średniowiecza. Sermones dominicales et festivales z tzw. kolekcji Piotra z Miłosławia, Kielce 2007.

Bracha Krzysztof, Leńczuk Mariusz, Stowo-Pismo-Sacrum. Cztery studia z dziejów kultury religijnej w Polsce późnego średniowiecza, Warszawa 2020.

Bylina Stanisław, Chrystianizacja wsi polskiej u schytku średniowiecza, Warszawa 2002.

Chachaj Jacek, Bliżej schizmatyków niż Krakowa... Archidiakonat lubelski w XV i XVI wieku, Lublin 2012.

Cossar Roisin, Clerical "Concubines” in Northern Italy during the Fourteenth Century, „Journal of Women's History”, 23 (2011) s. 111-132.

Derwich Marek, Erem św. Katarzyny pod Łysica i benedyktyni świętokrzyscy, w: LudzieKościót - Wierzenia. Studia z dziejów kultury i spoteczeństwa Europy Środkowej (średniowiecze - wczesna epoka nowożytna), red. W. Iwańczak, S.K. Kuczyński, Warszawa 2001 , s. $135-144$

Derwich Marek, Materiaty do stownika historyczno-geograficznego dóbr i dochodów dziesięcinnych benedyktyńskiego opactwa św. Krzyża na Łysej Górze do 1819 r., Wrocław 2000.

Derwich Marek, Opactwo świętokrzyskie w epoce przedrozbiorowej, w: Klasztor na Świętym Krzyżu w polskiej kulturze narodowej, red. D. Olszewski, R. Gryz, Kielce 2000, s. $49-69$.

Długosz Teofil, Sprawy liturgiczne w XVI w. w diecezji krakowskiej, „Ruch Biblijny i Liturgiczny", 4 (1951) nr 4, s. 297-318. https://doi.org/10.21906/rbl.2449

Dola Kazimierz, Duchowieństwo w spoleczeństwie polskim w przededniu reformacji (1450-1520), w: Studia nad poczatkami reformacji protestanckiej na Ślasku, Opole 2009, s. 23-49.

Dunin-Wąsowiczowa Anna, Charakter i wielkość osiedli, w: Województwo sandomierskie $w$ drugiej połowie XVI wieku, red. W. Pałucki, cz. 2: Komentarz, indeksy, Warszawa 1993, s. 77-86.

Dyl Janusz, Ksiązki teologiczne polskich drukarń XV i XVI wieku, „Archiwa, Biblioteki i Muzea Kościelne", 69 (1998) s. 101-170. https://doi.org/10.31743/abmk.8799 
Flaga Jerzy, Bractwa religijne $w$ archidiakonacie lubelskim do początków XVII wieku (1604), „Roczniki Humanistyczne”, 21 (1973) s. 141-169.

Flaga Jerzy, Bractwa religijne w Rzeczypospolitej w XVII i XVIII wieku, Lublin 2004.

Garbacik Józef, Wizytacja kolegiaty kieleckiej przez kardynała Jerzego Radziwitła 2 września 1598, „Radostowa”, 3 (1938) s. 64-67.

Glemma Tadeusz, Wizytacje diecezji krakowskiej z lat 1510-1570, „Nasza Przeszłość”, 1 (1946) s. 43-96.

Główka Dariusz, Majątek osobisty duchowieństwa katolickiego w Koronie w XVII i XVIII wieku, Warszawa 2004.

Górski Karol, Zarys dziejów duchowości w Polsce, Kraków 1986.

Grabkowski Marcin, Kształtowanie się sieci parafialnej w prepozyturze kieleckiej w czasach średniowiecza, „Res Gestae”, 12 (2012) s. 77-109.

Guzowski Piotr, Chłopi i pieniądze na przełomie średniowiecza i czasów nowożytnych, Kraków 2008.

Guzowski Piotr, Stan i perspektywy badań nad gospodarstwem chtopskim przełomu średniowiecza i czasów nowożytnych, w: Folwark - wieśs - latyfundium. Gospodarstwo wiejskie $w$ Rzeczypospolitej $w$ XVI-XVIII wieku, red. J. Muszyńska, S. Kazusek, J. Pielas, Kielce 2009, s. 9-18.

Hanusiewicz-Lavallee Mirosława, Dawne $i$ nowe. Tożsamość wyznaniowa katolików świeckich w potrydenckiej Rzeczypospolitej, w: Formowanie kultury katolickiej w dobie potrydenckiej. Powszechność i narodowość katolicyzmu polskiego, red. J. Dąbkowska-Kujko, Warszawa 2016, s. 103-144.

Inglot Stefan, Stan i rozmieszczenie uposażenia biskupstwa krakowskiego w połowie XV wieku. Próba odtworzenia zaginionej części Liber beneficiorum Długosza, Lwów 1925.

Izydorczyk-Kamler Anna, Praca najemna na wsi małopolskiej w XVI i pierwszej połowie XVII wieku, „Kwartalnik Historyczny”, 97 (1990) nr 1-2, s. 3-31.

Jabłońska Anna, Obraz duchowieństwa parafialnego w świetle wizytacji Wincentego de Seve (1608-1609) - wybrane aspekty, „Roczniki Humanistyczne”, 65 (2017) nr 2: Historia, s. 5-22.

Justyniarska-Chojak Katarzyna, Książki w mieszczańskich inwentarzach pośmiertnych z terenu Małopolski (XVI-XVII wiek), w: Historia magistra vitce est... Studia z dziejów społeczno-politycznych, gospodarczych i kulturalnych. Księga jubileuszowa dedykowana prof. zw. dr. hab. Wiesławowi Cabanowi z okazji 45-lecia pracy zawodowej, red. L. Michalska-Bracha, M. Przeniosło, B. Wojciechowska, Kielce 2016, s. 57-66.

Kamler Anna, Chłopi jako pracownicy najemni na wsi małopolskiej w XVI $i$ w pierwszej połowie XVII wieku, Warszawa 2005.

Kaniewska Irena, Lanckoroński (Wodzisławski) Krzysztof h. Zadora, w: Polski Słownik Biograficzny, red. E. Rostworowski, t. 16, Wrocław 1971, s. 443-445; Internetowy Polski Słownik Biograficzny, https://www.ipsb.nina.gov.pl/a/biografia/krzysztof -lanckoronski-h-zadora (dostęp: 17.09.2020).

Karbownik Henryk, Ciężary stanu duchownego w Polsce na rzecz państwa od 1381 do połowy XVII wieku, Lublin 1980.

Kardyś Piotr, Parafie w średniowieczu na obszarze obecnej diecezji kieleckiej: stan i perspektywy badań, „Kieleckie Studia Teologiczne”, 13 (2014) s. 49-68.

Kardyś Piotr, Przyczynki do dziejów księgozbioru Kolegiaty Kieleckiej w średniowieczu $i$ okresie wczesnonowożytnym, „Biuletyn Biblioteki Jagiellońskiej”, $56-57$ (20062007) s. 17-44. 
Kardyś Piotr, Z dziejów miasta klasztornego Wachocka w średniowieczu i okresie wczesnonowożytnym: warstwa źródłowa i interpretacje historyczne, „Nasza Przeszłość”, $123(2015)$ s. 247-263

Kiryk Feliks, Urbanizacja rejonu między Itżanka, Kamienna i Wisła do końca XVI stulecia, „Annales Universitatis Pedagogicae Cracoviensis, Studia Logopaedica IV: Język - kultura - edukacja", 96 (2011), s. 242-256.

Kłoczowski Jerzy, Problem mendykantów i kaznodziejstwa w Polsce średniowiecznej, w: Ludzie - Kościót - Wierzenia. Studia z dziejów kultury i społeczeństwa Europy Środkowej (średniowiecze - wczesna epoka nowożytna), red. W. Iwańczak, S.K. Kuczyński, Warszawa 2001, s. 145-149.

Koczerska Maria, Testament kanonika tarnowskiego i plebana Wszystkich Świętych w Krakowie, w: Ludzie - Kościót - Wierzenia. Studia z dziejów kultury i społeczeństwa Europy Środkowej (średniowiecze - wczesna epoka nowożytna), red. W. Iwańczak, S. K. Kuczyński, Warszawa 2001, s. 237-254.

Koperek Stefan, Mszat, w: Encyklopedia katolicka, t. 13, red. E. Gigilewicz, Lublin 2009, kol. 461-463.

Korzo Margarita A., Wzory kazań w składzie agend. Przyczynek do reformy katolickiej w Rzeczypospolitej drugiej połowy XVI wieku, w: Z historii kultury staropolskiej. Studia ofiarowane Urszuli Augustyniak, red. A. Bartoszewicz, A. Karpiński, M. Ptaszyński, A. Zakrzewski, Warszawa 2020, s. 235-244.

Kowalska Halina, Jan Sienieński z Pomorzan, h. Dębno, w: Polski Słownik Biograficzny, t. 37, red. E. Rostworowski, Kraków 1996-1997, s. 183-188.

Kowalski Marek Daniel, Dzieje autografu katedralno-kolegiackiej części Liber beneficiorum dioecesis Cracoviensis Jana Długosza, „Studia Źródłoznawcze”, 46 (2009) s. 8394.

Kowalski Waldemar, Jan Dtugosz a tzw. szlachecki antyklerykalizm w siedemnastowiecznej Rzeczypospolitej, w: Jan Dlugosz - w kręgu badań historyków i literaturoznawców, red. T. Giergiel, Sandomierz 2017, s. 187-207.

Kowalski Waldemar, Man and God: The First Three Commandments in the Polish Catholic Catechisms of the 1560s-1570s, w: The Ten Commandments in Medieval and Early Modern Culture, red. Y. Desplenter, J. Pieters, W. Melion, Leiden-Boston 2017, s. 219-238. https://doi.org/10.1163/9789004325777 013

Kowalski Waldemar, Peasants and 'Sectarians'. On the Ineffectiveness of Evangelical Persuasion in Sixteenth-Century Poland, w: Bridging the Historiographical Divides, red. É. Boillet, I. Johnson, Turnhout 2021 (w druku).

Kowalski Waldemar, Trydenckie wyzwania a duszpasterstwo w kieleckiej parafii kolegiackiej drugiej połowy XVI wieku, w: Jednostka, rodzina i struktury społeczne w perspektywie historycznej. Księga jubileuszowa dedykowana Profesorowi Cezaremu Kuklo, red. P. Łozowski, R. Poniat, Warszawa 2021 (w druku).

Kowalski Waldemar, Uposażenie parafii archidiakonatu sandomierskiego $w$ XV-XVIII wieku, Kielce 1998.

Kracik Jan, Najstarsze akta kongregacji dekanalnych w Archiwum Kurii Metropolitalnej w Krakowie, „Archiwa, Biblioteki i Muzea Kościelne”, 29 (1974) s. 261-272. https:// doi.org/10.31743/abmk.7028

Kracik Jan, Potrydencki system rekrutacji duchowieństwa $w$ diecezji krakowskiej XVIXVIII wieku, „Analecta Cracoviensia”, 10 (1978) s. 471-493.

Kracik Jan, Prawie wielebni, Kraków 2011.

Kracik Jan, Przeciw reformacji, w: Kościół krakowski w tysiącleciu, Kraków 2000, s. 169303. 
Kracik Jan, Raków katolicki, „Odrodzenie i Reformacja w Polsce”, 30 (1985) s. 95-110.

Kracik Jan, Zasoby Archiwum Kurii Metropolitalnej w Krakowie, „Analecta Cracoviensia", 9 (1977) s. 476-477.

Krawiec Adam, Seksualność w średniowiecznej Polsce, Poznań 2000.

Kumor Bolesław, Dzieje diecezji krakowskiej do roku 1795, red. J. Urban, t. 2, 4, Kraków 1999, 2002.

Kumor Bolesław, Statuty Bractwa Kapłańskiego Oficjałatu Pilzneńskiego przy kościele św. Jana Chrzciciela w Pilznie, „Archiwa, Biblioteki i Muzea Kościelne”, 5 (1962) s. 385-392. https://doi.org/10.31743/abmk.6402

Kuśmierczyk Rafał, Problem braku duchowieństwa parafialnego $w$ archidiakonacie wtocławskim w końcu XVI w., w: Nad społeczeństwem staropolskim, t. 1: Kultura, instytucje, gospodarka w XVI-XVIII stuleciu, red. K. Łopatecki, W. Walczak, Białystok 2007, s. 359-371

Kuśmierczyk Rafał, Problematyka „Listu pasterskiego” kard. Jerzego Radziwiłła z roku 1593, „Nasza Przeszłość”, 100 (2003) s. 223-256.

Kwaśniewski Andrzej, Księgozbiór kanonika kieleckiego Wojciecha Strzemeskiego († 1602 r.) $w$ świetle inwentarza z 1650 roku, „Rocznik Kolbuszowski”, 12 (2012) s. $87-107$.

Kwaśniewski Andrzej, Księgozbiór kapituły kieleckiej w świetle inwentarza z 1598 r., „Archiwa, Biblioteki i Muzea Kościelne”, 99 (2013) s. 43-92.

Kwaśniewski Andrzej, Księgozbiory prywatne zachowane w bibliotece kapituły kieleckiej (XV-XVIII wiek), „Biuletyn Biblioteki Jagiellońskiej”, 62 (2012) s. 69-95.

Leksykon liturgii, oprac. B. Nadolski, Poznań 2006.

Litak Stanisław, Od reformacji do oświecenia. Kościót katolicki w Polsce nowożytnej, Lublin 1994.

Litak Stanisław, Parafie w Rzeczypospolitej w XVI-XVIII wieku. Struktura, funkcje spoteczno-religijne i edukacyjne, Lublin 2004.

Małecki Aleksander, „Historyków nie zaniechaj czytać... ”: studia nad twórczościa historyczna Marcina Kromera i jej renesansowa recepcja, Poznań 2013.

Massaut Jean-Pierre, Josse Clichtove, l'humanisme et la réforme du clergé, vol. 1-2, Paris 1968

M[erczyng] H[enryk], Zbory i senatorowie protestanccy $w$ dawnej Rzeczypospolitej, Warszawa 1904.

Michałowska Teresa, Średniowiecze, Warszawa 1995.

Modzelewska Bożena, Teofilakt z Ochrydy, w: Encyklopedia katolicka, t. 19, red. E. Gigilewicz, Lublin 2013, kol. 649.

Muessig Carolyn, The Stigmata in Medieval and Early Modern Europe, Oxford 2020.

Noga Zdzisław, Krakowska rada miejska w XVI wieku. Studium o elicie władzy, Kraków 2003.

Nowak Andrzej, Przeobrażenia struktury społecznej ludności wiejskiej w Polsce w okresie panowania systemu folwarczno-pańszczyźnianego (XV-XVIII wieku). Próba ujęcia modelowego, w: Badania nad historia gospodarczo-społeczna w Polsce (Problemy i metody), Warszawa-Poznań 1978, s. 131-146.

Nowakowska Natalia, From Strassburg to Trent: Bishops, Printing and Liturgical Reform in the Fifteenth Century, „Past and Present”, 213 (2011) s. 3-39.

Osial Wojciech, Historia katechizmu. Geneza i rozwój katechizmu w Kościele katolickim od I do XVI wieku, Warszawa 2013.

Ottone Andrea, Pastoral Care and Cultural Accuracy: Book Collections of Secular Clergy in Three Southern Italian Dioceses, w: Documenting the Early Modern Book World: 
Inventories and Catalogues in Manuscript and Print, red. M. Walsby, N. Constantinidou, Leiden-Boston 2013, s. 231-260.

Ozorowski Edward, Szyszkowski Marcin h Ostoja, w: Słownik polskich teologów katolickich, red. H.E. Wyczawski, t. 4, Warszawa 1983, s. 296-298.

Pałucki Władysław, Przynależność własnościowa osad, w: Województwo sandomierskie $w$ drugiej połowie XVI wieku, cz. 2: Komentarz, indeksy, red. W. Pałucki, Warszawa 1993, s. 87-98.

Pietras Tadeusz, Produkcja katolickiej książi liturgicznej w Polsce od końca XV do połowy XVII wieku, „Archiwa, Biblioteki i Muzea Kościelne”, 39 (1979) s. 169-189

Poniewozik Leszek, Średniowieczny kościót i parafia w Bodzentynie, w: Bodzentyn. Studia z dziejów miasta, red. K. Bracha, B. Wojciechowska, Kielce 2005, s. 99-110.

Pośpiech Andrzej, Pułapka oczywistości. Pośmiertne spisy ruchomości szlachty wielkopolskiej z XVII wieku, Warszawa 1992.

Prokop Krzysztof Rafał, Fabrica ecclesiae. Budowa i utrzymanie katolickich miejsc kultu w diecezji krakowskiej w czasach nowożytnych, Warszawa- Kraków 2011.

Przybyszewski Bolesław, Krakowskie duchowieństwo parafialne przy końcu średniowiecza, „Folia Historica Cracoviensia”, 2 (1994) s. 31-39. https://doi.org/10.31743/ abmk.7255

Repertorium biblicum medii aevi, t. 3: Commentaria, red. F. Stegmüller, Matritii 1981.

Rickauer Hans-Christian, Rechtfertigung und Heil. Die Vermittlung von Glaube und Heilshandeln in der Auseinandersetzung mit der reformatorischen Lehre bei Konrad Klinge (1483/84-1556), Leipzig 1986.

Rojewski Andrzej, Recepcja ksiag liturgicznych soboru trydenckiego w archidiakonacie dobrzyńskim w latach 1597-1609, „Studia Płockie”, 7 (1979) s. 187-203.

Samek Marta, Kielce XVII-XVIII wiek. Stownik biograficzny, Kielce 2003.

Skierska Izabela, Obowiazek mszalny w średniowiecznej Polsce, Warszawa 2003.

Skierska Izabela, Pleban w późnośredniowiecznej Polsce, w: Kolory i struktury średniowiecza, red. W. Fałkowski, Warszawa 2004, s. 155-182.

Sczaniecki Paweł, Stużba Boża w dawnej Polsce. Studia o Mszy świętej, Kraków 2020.

Słowiński Jan Zbigniew, Katechizmy katolickie w języku polskim od XVI do XVIII wieku, Lublin 2005.

Szady Bogusław, Prawo patronatu w Rzeczypospolitej w czasach nowożytnych. Podstawy i struktura, Lublin 2003.

Szanser Jan, Ustrój miasta Kielc na przełomie XVI i XVII wieku, „Rocznik Muzeum Narodowego w Kielcach", 12 (1982) s. 27-53.

Szczygielski Krzysztof, Problematyka konkubinatu w uchwałach soborów powszechnych XII-XVI wieku, w: Miscellanea historico-iuridica, t. 4, red. A. Lityński, P. Fiedorczyk, Białystok 2006, s. 41-57.

Szczyglak Maciej, Klasztor ojców bernardynów w Świętej Katarzynie, w: Kościół katolicki w Małopolsce w średniowieczu i we wczesnym okresie nowożytnym, red. W. Kowalski, J. Muszyńska, Kielce-Gdańsk 2001, s. 97-113.

Ślusarska Magdalena, Odnowa życia kościelnego i pogłębienie świadomości religijnej wiernych $w$ świetle zaleceń przedstawicieli episkopatu Rzeczypospolitej Obojga Narodów w XVIII wieku - rekonesans, w: Wiek XVIII - między tradycja a oświeceniowa współczesnością. Hermeneutyka wartości religijnych, red. B. Kuczera-Chachulska, T. Chachulski, współpraca J. Snopek, Warszawa 2017, s. 105-155.

Terlikowski Adam, Ograniczenia wolności zawierania małżeństw ludności chłopskiej wynikajace ze stosunku poddaństwa w Polsce nowożytnej na tle wybranych krajów europejskich, w: Prawo blisko człowieka: $z$ dziejów prawa rodzinnego i spadkowego. Ma- 
teriały konferencji zorganizowanej przez Sekcję Historii Państwa i Prawa Towarzystwa Biblioteki Stuchaczów Prawa Uniwersytetu Jagiellońskiego, Kraków 7-8 marca 2007 $r$., red. M. Mikuła, Kraków 2008, s. 49-57.

Topolski Jerzy, Przełom gospodarczy w Polsce XVI wieku i jego następstwa, Poznań 2000. Trawkowski Stanisław, Ku odległym początkom i dawnym dziejom Bodzentyna, w: Bodzentyn. Z dziejów miasta w XII-XX wieku, red. K. Bracha, Kielce 1998, s. 11-23.

Tyrawa Jan, Nowopolczyk, Nowopolski, Novicampianus Wojciech, w: Encyklopedia katolicka, t. 14, red. E. Gigilewicz, Lublin 2010, kol. 77.

Universal Short Title Catalogue (USTC), https://www.ustc.ac.uk/.

Urban Wacław, Gabriel z Przemyśla, sandomierski renesansowy księżyna, prawnik i pieniacz, w: Ludzie - Kościól - Wierzenia. Studia z dziejów kultury i społeczeństwa Europy Środkowej ('́redniowiecze - wczesna epoka nowożytna), red. W. Iwańczak, S.K. Kuczyński, Warszawa 2001, s. 283-286.

Urban Wacław, Reformacja w życiu wsi małopolskiej, „Kieleckie Studia Historyczne”, [1] (1976) s. 7-28

Werner, Cling, Konrad, w: Allgemeine Deutsche Biographie, vol. 4, Berlin 1876, s. 333-334, https://www.deutsche-biographie.de/pnd118815911.html\#adbcontent (20.07.2020).

Wiślicz Tomasz, „Jak gdyby wśród pogan lub heretyków”. Polityka potrydenckiego Kościoła wobec religii ludowej i jej osobliwości w Rzeczypospolitej, w: Staropolski ogląd świata. Rzeczpospolita między okcydentalizmem a orientalizacją. Przestrzeń wyobrażeń, red. R. Kołodziej, F. Wolański, t. 2, Toruń 2009, s. 31-42.

Wiślicz Tomasz, Shepherds of the Catholic Flock: Polish Parochial Clergy, Popular Religion, and the Reception of the Council of Trent, w: Gelehrte Geistlichkeit-geistliche Gelehrte. Beiträge zur Geschichte des Bürgertums in der Frühneuzeit, red. L. SchornSchütte, Berlin 2012, s. 25-52.

Wiśniewski Jan, Dekanat iłżecki, Radom 1911.

Wiśniowski Eugeniusz, Liczebność duchowieństwa diecezjalnego na ziemiach polskich w pierwszej połowie XVI w., „Roczniki Humanistyczne”, 16, 2 (1968) s. 43-77.

Wiśniowski Eugeniusz, Materiały do stanu liczebnego duchowieństwa i służby kościelnej w diecezji krakowskiej w pierwszej połowie XVI w., „Archiwa, Biblioteki i Muzea Kościelne", 18 (1969), s. 189-288.

Wiśniowski Eugeniusz, Parafie w średniowiecznej Polsce. Struktura i funkcje społeczne, Lublin 2004.

Wiśniowski Eugeniusz, Wartość beneficjów plebańskich $w$ diecezji krakowskiej w świetle księgi dochodów beneficjów z roku 1529, „Roczniki Humanistyczne”, 35 (1987) s. 7181.

Witkowska Aleksandra, Kult jasnogórski w formach pąniczych do połowy XVII wieku, „Studia Claromontana”, 5 (1984) s. 148-223.

Wood Robert A., The Ownership of Books amongst the London Rectors in the Late Fourteenth and Fifteenth Centuries, „Medieval Prosopography”, 33 (2018) s. 195-208.

Wójcik Walenty, Organizacja i działalność oficjalatu okręgowego w Kielcach w latach 1551-1635, „Roczniki Teologiczno-Kanoniczne”, 10 (1963) z. 3, s. 29-37.

Wółkiewicz Ewa, The ecclesiastical proletariat? The income of the lesser clergy in the late Middle Ages exemplified with the accounting book of St. Martin's altar in Nysa, „Kwartalnik Historii Kultury Materialnej”, 67 (2019) s. 3-16.

Wyczawski Hieronim Eugeniusz, Biblioteki parafialne $w$ diecezji krakowskiej u schytku XVI wieku, „Polonia Sacra”, 6 (1953-1954) z. 2, s. 114-142.

Wyczawski Hieronim Eugeniusz, Biblioteki parafialne $w$ diecezji krakowskiej u schytku XVI wieku, „Polonia Sacra”, 7 (1955) z. 1-2, s. 27-68, 159-173. 
Wyczawski Hieronim Eugeniusz, Studia nad wewnętrznymi dziejami kościelnymi w Małopolsce na schytku XVI wieku, „Prawo Kanoniczne”, 7 (1964) s. 45-126

Wyrobisz Andrzej, Małe miasta i ich mieszkańcy w późnośredniowiecznej $i$ wczesnonowożytnej Polsce, „Przegląd Historyczny”, 95 (2004) nr 1, s. 101-108.

Zahajkiewicz Marek T., Miejsce zakonów w duszpasterstwie średniowiecznych miast, w: Klasztor w mieście średniowiecznym i nowożytnym, red. M. Derwich, A. Pobóg -Lenartowicz, Wrocław-Opole 2000, s. 309-314.

Zalewski Zbigniew, Pobożność eucharystyczna, jej cechy i charakter, „,Ruch Biblijny i Liturgiczny", 39 (1986) nr 4, s. 305-316. https://doi.org/10.21906/rbl.1612

Zumkeller Adolar, Hoffmeister, Johannes, w: Neue Deutsche Biographie, t. 9, Berlin 1972, s. 441, https://www.deutsche-biographie.de/pnd115447075.html\#ndbcontent (dostęp: 10.07.2020).

Zygner Leszek, Późnośredniowieczne synody narzędziem reformy Kościoła, w: Ecclesia semper reformanda. Kryzysy i reformy średniowiecznego Kościoła, red. T. Gałuszka, T. Graff, G. Ryś, Kraków 2013, s. 423-441.

Zygner Leszek, Synody diecezjalne metropolii gnieźnieńskiej na przełomie XIV i XV wieku (Gniezno - Kraków - Płock - Poznań - Włocławek), w: Kultura prawna w Europie Środkowej, red. A. Barciak, Katowice 2006, s. 177-192.

\title{
THE PROVOSTRY OF KIELCE IN THE SIXTEENTH CENTURY: THE FAITHFUL AND THE CLERGY
}

\begin{abstract}
The article discusses the cure of souls in the Kielce Provostry in the sixteenth century. The source-base comprises the 1529 benefice taxation register of the Cracow Diocese, the records of the local consistory court, the Kielce collegiate parish registers, which date back to the $1560 \mathrm{~s}$, and the $1590 \mathrm{~s}$ visitation protocols. There were twenty-nine parishes in the territory under the provost of the Kielce collegiate chapter. It was predominantly a rural area with only seven towns, whose economic and administrational roles were limited to the demesnes in which they were located. With a few exceptions, the local landowners were ecclesiastical institutions, first and foremost the Bishop of Cracow, the Benedictine monastery of the Holy Cross and the Cistercian monastery at Wąchock. Thus Reformation ideas did not spread in the Provostry, in contrast to neighbouring lands, where noble patronage played a key role.

The parish benefices in the Provostry of Kielce were among the best endowed in the whole diocese. The majority of pastors employed curates, usually one, though occasionally two. The number of parishes with curates fell from 79 to 62 percent between the 1520 s and the 1590 s. In 1529,44 percent of curates enjoyed higher incomes than the Provostry average, but in 1597 parish priests with above-average incomes constituted only 27 percent. There is no straight correlation between the level of parish incomes and the decision to employ a curate. Although the salaries of the lower clergy were usually only around 15 percent of the overall annual parish revenues, there was no move to raise them. Salaries were supplemented with fees for administering sacraments, but all we know about them is that they were on the decrease througho-
\end{abstract}


ut the century. The salaries of the Kielce lower chapter that substituted for non-resident canons and prelates constituted only 16 per cent of its total annual income. The curates' testaments confirm the impression that generally, if their lives were far from luxurious, they were certainly not poor.

The majority of rectors and curates in the Provostry were born to burgher or peasant families of the Cracow diocese, and those of noble birth constituted at most 20 percent. The lowest reaches of Polish society completed elementary education at most, hence mass literacy was uncommon. As no more than 15 percent of the Provostry clergy enrolled at Cracow University, training under the guidance of the local parish priest was the only route to ordination for most of them. The lower clergy were aware of the importance of books for the cure of souls, and a breviary, not necessarily the Roman Breviary, was commonly relied upon. Pre-Tridentine liturgical manuals were in use in some parishes down to the end of the sixteenth century. Rarely did visitations list sermon collections, which suggests that the priests must have relied on homilies published as part of diocesan guides (agendæ). Parish and private libraries were usually small, mostly containing only liturgical manuals and books useful on an everyday basis; catechisms are rarely mentioned.

There is no straight correlation between the variety of books in the parish library and the quality of the cure of souls, as is demonstrated by the case of the Kielce collegiate parish. From the 1560s through to the end of the century the six to eight local chapter vicars exercised care only over a minority of local parishioners, perhaps some 5,500. In 1597-98, religious brotherhoods were active only in around 20 percent of parishes, and efforts to expand their activities were frequently in vain.

It was clearly difficult to engage parishioners beyond Sunday mass attendance, and to do more than persuade them to memorise the rudiments of the faith and contribute to bringing offertories. In the second half of the sixteenth century, religious life in the Kielce Provostry was still to a considerable extent a continuation of the mediaeval world, in which the programme of reform was limited to the strengthening of Church discipline.

Keywords: Cracow diocese; Church reform; cure of souls; libraries; testaments; Church discipline 